\title{
Macroeconomic Crises since 1870
}

ABSTRACT We build on Angus Maddison's data by assembling international time series from before 1914 on real per capita personal consumer expenditure, $\mathrm{C}$, and by improving the GDP data. We have full annual data on $\mathrm{C}$ for twenty-four countries and GDP for thirty-six. For samples starting at 1870 , we apply a peak-to-trough method to isolate economic crises, defined as cumulative declines in C or GDP of at least 10 percent. We find 95 crises for $\mathrm{C}$ and 152 for GDP, implying disaster probabilities of $3 \frac{1}{2}$ percent a year, with mean size of 21-22 percent and average duration of $3 \frac{1}{2}$ years. Simulation of a Lucas-tree model with i.i.d. shocks and Epstein-Zin-Weil preferences accords with the observed average equity premium of around 7 percent on levered equity, using a coefficient of relative risk aversion of 3.5. This result is robust to several perturbations, except for limiting the sample to nonwar crises.

A n earlier study by Barro used Thomas Rietz's insight on rare economic disasters to explain the equity premium puzzle introduced by Rajnish Mehra and Edward Prescott. ${ }^{1}$ Key parameters were the probability $p$ of disaster and the distribution of disaster sizes $b$. Because large macroeconomic disasters are rare, pinning down $p$ and the $b$ distribution from historical data requires long time series for many countries, along with the assumption of rough parameter stability over time and across countries. Barro's 2006 study relied on long-term international GDP data for thirtyfive countries from Angus Maddison's 2003 dataset. ${ }^{2}$ Using the definition of an economic disaster as a peak-to-trough fall in GDP per capita of at least 15 percent, Barro found sixty disasters, corresponding to $p=1.7$ percent a year. The average disaster size was 29 percent, and the empirical size distribution was used to calibrate a model of asset pricing.

1. Barro (2006); Rietz (1988); Mehra and Prescott (1985).

2. Maddison (2003). 
The underlying asset pricing theory relates to consumption, rather than GDP. This distinction is especially important for wars. For example, in the United Kingdom during the two world wars, GDP increased while consumer expenditure fell sharply, the difference representing mostly added military spending. Maddison's 2003 dataset provides national accounts information only for GDP. Our initial idea was to add consumption, which we approximate by real personal consumer expenditure, $\mathrm{C}$, because of difficulties in most cases in separating durable goods consumption from that of nondurable goods and services. (We discuss later the breakdown of $\mathrm{C}$ into durables versus nondurables for a subset of countries with available data for crisis periods.) We have not assembled data on government consumption, some of which may substitute for $\mathrm{C}$ and thereby affect asset pricing. However, this substitution is probably unimportant for military expenditure, which is the type of government spending that moves sharply during some disaster events.

Maddison's 2003 dataset, with updates available on the Internet at www.ggdc.net/maddison, represents a monumental and widely used resource for international studies using long-term GDP data. Although much of the information is sound, close examination revealed many problems. For our purposes the most important shortcoming is that Maddison tends to fill in missing data with doubtful assumptions, and this practice applies especially to major crises.

As examples of problems, Maddison assumed that Belgium's GDP during World Wars I and II moved in tandem with France's; that Mexico's GDP between 1910 and 1919, the period including its revolution and civil war, followed a smooth trend, with no crisis; that GDP for Colombia moved over more than a decade with the average of Brazil and Chile; and that GDP in Germany for the crucial years 1944-46 followed a linear trend. There were also mismatches between originally cited works and published series for GDP in Japan and Austria at the end of World War II, in Greece during World War II and its civil war, and in South Korea during World War II and the Korean War.

Given these and analogous problems, our project expanded to estimating long-term GDP for many countries. The Maddison information was often usable, but superior estimates or longer time series could often be constructed. In addition, results from recent major long-term national accounts projects for several countries are now available and have not been incorporated into Maddison's Internet updates. These studies cover Argentina, Brazil, Colombia, Greece, Sweden, and Taiwan. Table A1 in appendix A summarizes the key differences, by country and time period, between Mad- 
dison's and our GDP data. Details and a list of data sources are available on the Internet (www.economics.harvard.edu/faculty/barro/data_sets_barro).

The first section of the paper describes the long-term data that we have assembled on real per capita personal consumer expenditure, $\mathrm{C}$, and real per capita GDP. Our main analysis uses annual data from before 1914 for twenty-four countries on $\mathrm{C}$ and thirty-six countries on GDP. The second section discusses the long-term data that we use on rates of return for stocks, bills, and bonds. This information comes mostly from Global Financial Data. The third section describes our measurement of $\mathrm{C}$ and GDP crises, based primarily on peak-to-trough fractional declines during the crises. The fourth section discusses the limited information available on the breakdown of $\mathrm{C}$ into durables versus nondurables and services.

The fifth section compares disaster sizes and timing based on $\mathrm{C}$ with those based on GDP. The sixth section uses the crises data to measure disaster probabilities and frequency distributions of disaster sizes. The seventh section summarizes a representative-agent Lucas-tree model that relates disaster experience to expected rates of return and the equity premium. The eighth section simulates the Lucas-tree model using the empirically estimated disaster probability and the frequency distribution of disaster sizes. The simulated model with a reasonable coefficient of relative risk aversion accords reasonably well with observed equity premia. The ninth section modifies the simulation to use observed real stock-price changes to gauge crisis returns on stocks. We also discuss the low average real bill returns observed during crises. The final section concludes with plans for additional research.

\section{Long-Term Data on Personal Consumer Expenditure and GDP}

We are dealing with national accounts data for forty-two countries. This sample is the universe of countries that seem to be promising for constructing reasonably accurate annual data since before World War I. The current study focuses on the countries for which we have thus far assembled annual data from before 1914 to 2006 on C (twenty-four countries) and GDP (thirty-six countries).

Table 1 shows a list of included countries and starting years. The top panel applies to twenty-one "OECD countries" (not including Turkey or recently acceding members); seventeen of these are in our $\mathrm{C}$ sample, and all twenty-one are in our GDP sample. The bottom panel covers eighteen "non-OECD" countries, of which seven are in our C sample, and fifteen are in our GDP sample. The three countries that we are studying that are 
Table 1. Starting Dates and Missing Values for Consumer Expenditure and GDPa

\begin{tabular}{|c|c|c|c|c|}
\hline \multirow[b]{2}{*}{ Country } & \multicolumn{2}{|c|}{ Starting dates } & \multicolumn{2}{|c|}{ Missing values } \\
\hline & $C$ & $G D P$ & $C$ & $G D P$ \\
\hline \multicolumn{5}{|l|}{ OECD countries ${ }^{\mathrm{b}}$} \\
\hline Australia & 1901 & 1820 & & \\
\hline Austria & $1913^{\mathrm{c}}$ & 1870 & $\begin{array}{c}1919-23, \\
1945-46\end{array}$ & \\
\hline Belgium & 1913 & 1846 & & \\
\hline Canada & 1871 & 1870 & & \\
\hline Denmark & 1844 & 1818 & & \\
\hline Finland & 1860 & 1860 & & \\
\hline France & 1824 & 1820 & & \\
\hline Germany & 1851 & 1851 & & \\
\hline Greece & $1938^{\mathrm{c}}$ & $1833^{\mathrm{e}}$ & & 1944 \\
\hline Iceland & $1945^{\mathrm{c}}$ & 1870 & & \\
\hline Italy & 1861 & 1861 & & \\
\hline Japan & 1874 & 1870 & & \\
\hline Netherlands & 1814 & 1807 & & \\
\hline New Zealand & $1939^{c}$ & 1870 & $\begin{array}{c}1940-43 \\
1945-46\end{array}$ & \\
\hline Norway & 1830 & 1830 & & \\
\hline Portugal & 1910 & 1865 & & \\
\hline Spain & 1850 & 1850 & & \\
\hline Sweden & 1800 & 1800 & & \\
\hline Switzerland & 1851 & 1851 & & \\
\hline United Kingdom & 1830 & 1830 & & \\
\hline United States & 1869 & 1869 & & \\
\hline \multicolumn{5}{|c|}{ Non-OECD countries } \\
\hline Argentina & 1875 & 1875 & & \\
\hline Brazil & 1901 & 1850 & & \\
\hline Chile & 1900 & 1860 & & \\
\hline Colombia & $1925^{\mathrm{c}}$ & 1905 & & \\
\hline India & $1919^{c}$ & 1872 & & \\
\hline Indonesia & $1960^{c}$ & 1880 & & \\
\hline Malaysia & $1900^{c}$ & $1900^{\mathrm{d}}$ & 1940-46 & $1943-46$ \\
\hline Mexico & 1900 & 1895 & & \\
\hline Peru & 1896 & 1896 & & \\
\hline Philippines & $1950^{\mathrm{c}}$ & $1902^{\mathrm{f}}$ & & $1941-45$ \\
\hline Singapore & $1900^{c}$ & $1900^{\mathrm{d}}$ & $1940-47$ & 1940-49 \\
\hline South Africa & $1946^{\mathrm{c}}$ & 1911 & & \\
\hline South Korea & 1911 & 1911 & & \\
\hline Sri Lanka & $1960^{c}$ & 1870 & & \\
\hline Taiwan & 1901 & 1901 & & \\
\hline Turkey & $1923^{c}$ & $1923^{d}$ & & \\
\hline Uruguay & $1960^{c}$ & 1870 & & \\
\hline Venezuela & $1923^{\mathrm{c}}$ & 1883 & & \\
\hline
\end{tabular}

Source: Authors' construction; for details on sources and procedures see the online appendix at www. economics.harvard.edu/faculty/barro/data_sets_barro.

a. C represents real per capita personal consumer expenditure; GDP represents real per capita GDP. Missing values apply to each period between country starting date and 2006. Criterion for inclusion in samples is presence of continuous annual data back before World War I.

b. Excludes recently acceding members and Turkey.

c. Excluded from analysis for $\mathrm{C}$ sample because of insufficient coverage.

d. Excluded from analysis for GDP sample because of insufficient coverage.

e. Included in the GDP sample with data for $\log (\mathrm{GDP})$ in 1944 interpolated between values for 1943 and 1945. This interpolation does not affect the estimated decline in GDP during World War II.

f. Included in part of the analysis of GDP data despite the gap in information for 1941-45. This gap does not hinder estimating the cumulative contraction in GDP associated with World War II. 
omitted from table 1 because of insufficient progress with the data are Egypt, Ireland, and Russia. We start our analysis of growth rates in 1870, although earlier data are available in some cases.

Our present analysis uses growth rates of C and GDP and does not involve comparisons of levels across countries. Therefore we can use indexes of both variables, for example, setting their values at 100 for each country in 2000. However, the level comparisons matter for the construction of measures of C and GDP for groups of countries, such as the total of the OECD. To facilitate this analysis (and to allow for other uses of the data that depend on comparability of levels across countries), we set the level of per capita GDP for each country in 2000 to the purchasing power parity (PPP)-adjusted value in 2000 international dollars given in the World Bank's World Development Indicators (WDI). For per capita consumer expenditure, we set the level for each country in 2000 to the value given by the WDI for PPP-adjusted per capita GDP multiplied by the share of nominal personal consumer expenditure in the country's nominal GDP.

Sample selection issues particularly affect disaster studies because data tend to be absent during the worst crises, especially wars. As examples, Malaysia and Singapore have data on C and GDP since 1900 but are missing information during World War II. Inclusion of the incomplete Malaysian and Singaporean time series since 1900 in our analysis would bias downward the estimated disaster probabilities, since the missing periods almost surely contain crises. We take the approach of excluding cases with these kinds of selected gaps in the data. In addition to Malaysia and Singapore, we omit Turkey (whose C and GDP data start in 1923, after the Ottoman Empire's crisis during World War I), India for C (where the data start in 1919), and Austria for C (where the data start in 1913 but information is missing toward the ends of World Wars I and II). More broadly, our main response to this selection issue has been to try to expand the set of countries with at least roughly estimated full time series.

The construction of estimates of $\mathrm{C}$ relied on various procedures. In many cases we used existing long-term national accounts studies. Sometimes (for example, Canada before 1926) we estimated C as a residual, starting from GDP and subtracting estimates of the other components of GDP. Sometimes (for example, Switzerland before 1948 and Germany around World War I) we constructed C from quantities of specific consumption items, using estimates of expenditure shares to calculate changes in C. The details of our procedures are in our Internet report.

One issue is the treatment of border changes. An illustration is the reunification of Germany in late 1990 . We have data on per capita C and 
GDP for West Germany up to 1990 (ignoring, for now, the previous border changes) and also after 1990. We have data for unified Germany from 1991 on. Since per capita C and GDP in East Germany (not well measured before 1991) were much lower than in the West, the raw data on per capita quantities would show sharp drops in 1991 if we combined the West German values up to 1990 with the unified-Germany values thereafter. That is, this approach would treat the unification as a disaster event from the perspective of West Germans leading up to 1990. This perspective may or may not be accurate for this particular border change, ${ }^{3}$ but we do not want to apply this approach to border changes in general. This procedure would imply that the initially richer part inevitably regards the coming combination as a disaster, and vice versa for the poorer part.

Even without border changes, the use of per capita C or GDP as a macro variable neglects the distribution of expenditure and income within a country. This macroeconomic approach, valid under some conditions, ${ }^{4}$ assumes that we can apply a representative-agent framework to the macro variables, despite the underlying heterogeneity in productivity, wealth, and so on. In this case, the joining of West Germany with another state (East Germany) that happens to have distributions of expenditure and income with lower mean values need not invalidate the representative-agent representation. The appropriate macro-level procedure is then to smoothly paste together in 1990-91 the initial per capita series for West Germany with that for unified Germany thereafter. That is, the West German per capita growth rates apply up to 1991, and the unified Germany growth rates apply thereafterwith no discrete shift in levels of variables at the time of the reunification. We apply this methodology to all of our cases of border change because we think that this approach can yield satisfactory measures of per capita growth rates across these changes. However, this procedure can be misleading with regard to levels of variables. These issues do not affect our present analysis but would matter in the construction of measures of per capita C and GDP for broad groups of countries, such as the total of the OECD.

Table 2 reports means and standard deviations, by country, of annual growth rates of per capita $\mathrm{C}$ and GDP. We consider here only cases with annual data from 1914 or earlier. The sample periods end in 2006 and go

3. As an analogy, some South Koreans view a reunification with North Korea as a pending disaster.

4. For example, Caselli and Ventura (2000) show that the neoclassical growth model can provide a satisfactory representative-agent view of macroeconomic variables despite heterogeneity in underlying productivity and wealth. 
Table 2. Means and Standard Deviations of Annual Growth Rates of Consumer Expenditure and GDPa

\begin{tabular}{|c|c|c|c|c|}
\hline \multirow[b]{2}{*}{ Country } & \multicolumn{2}{|c|}{$C$} & \multicolumn{2}{|c|}{$G D P$} \\
\hline & Mean & $\begin{array}{l}\text { Standard } \\
\text { deviation }\end{array}$ & Mean & $\begin{array}{l}\text { Standard } \\
\text { deviation }\end{array}$ \\
\hline \multicolumn{5}{|l|}{ OECD countries } \\
\hline Australia & 0.0154 & 0.0506 & 0.0159 & 0.0423 \\
\hline Austria & - & - & 0.0217 & 0.0709 \\
\hline Belgium & 0.0189 & 0.0904 & 0.0203 & 0.0838 \\
\hline Canada & 0.0192 & 0.0474 & 0.0212 & 0.0511 \\
\hline Denmark & 0.0163 & 0.0538 & 0.0190 & 0.0370 \\
\hline Finland & 0.0239 & 0.0568 & 0.0237 & 0.0449 \\
\hline France & 0.0162 & 0.0674 & 0.0191 & 0.0642 \\
\hline Germany & 0.0189 & 0.0570 & 0.0212 & 0.0811 \\
\hline Greece $^{b}$ & - & - & 0.0210 & 0.1013 \\
\hline Iceland & - & - & 0.0254 & 0.0506 \\
\hline Italy & 0.0173 & 0.0370 & 0.0213 & 0.0471 \\
\hline Japan & 0.0248 & 0.0689 & 0.0277 & 0.0611 \\
\hline Netherlands & 0.0190 & 0.0854 & 0.0188 & 0.0757 \\
\hline New Zealand & - & - & 0.0143 & 0.0517 \\
\hline Norway & 0.0194 & 0.0380 & 0.0231 & 0.0361 \\
\hline Portugal & 0.0272 & 0.0448 & 0.0207 & 0.0431 \\
\hline Spain & 0.0204 & 0.0727 & 0.0200 & 0.0453 \\
\hline Sweden & 0.0208 & 0.0458 & 0.0230 & 0.0362 \\
\hline Switzerland & 0.0150 & 0.0623 & 0.0150 & 0.0399 \\
\hline United Kingdom & 0.0147 & 0.0283 & 0.0157 & 0.0293 \\
\hline United States & 0.0185 & 0.0360 & 0.0217 & 0.0498 \\
\hline \multicolumn{5}{|c|}{ Non-OECD countries } \\
\hline Argentina & 0.0189 & 0.0823 & 0.0164 & 0.0674 \\
\hline Brazil & 0.0277 & 0.0780 & 0.0192 & 0.0507 \\
\hline Chile & 0.0191 & 0.0905 & 0.0204 & 0.0596 \\
\hline Colombia & - & - & 0.0236 & 0.0229 \\
\hline India & - & - & 0.0140 & 0.0487 \\
\hline Indonesia & - & - & 0.0160 & 0.0556 \\
\hline Mexico & 0.0176 & 0.0655 & 0.0187 & 0.0421 \\
\hline Peru & 0.0174 & 0.0463 & 0.0207 & 0.0482 \\
\hline South Africa & - & - & 0.0130 & 0.0485 \\
\hline South Korea & 0.0293 & 0.0689 & 0.0352 & 0.0743 \\
\hline Sri Lanka & - & - & 0.0144 & 0.0455 \\
\hline Taiwan & 0.0344 & 0.0872 & 0.0386 & 0.0807 \\
\hline Uruguay & - & - & 0.0143 & 0.0787 \\
\hline Venezuela & - & - & 0.0251 & 0.0893 \\
\hline
\end{tabular}

Source: Authors' construction; for details on sources and procedures see the online appendix at www.economics.harvard.edu/faculty/barro/data_sets_barro.

a. C represents real per capita personal consumer expenditure; GDP represents real per capita GDP. Countries included are those with full data from before World War I, as indicated in table 1. Periods are from 1870 (or the later starting date with available data) through 2006. The Philippines is not included in this table because data are missing for more than one year.

b. Value of $\log ($ GDP) in 1944 is interpolated between the values for 1943 and 1945 . 
Table 3. Mean Annual Growth Rates of Consumer Expenditure and GDP across Countries, Various Periods ${ }^{a}$

\begin{tabular}{|c|c|c|c|c|c|c|}
\hline \multirow[b]{2}{*}{$\begin{array}{l}\text { Country sample } \\
\text { and period }\end{array}$} & \multicolumn{3}{|c|}{$C$} & \multicolumn{3}{|c|}{$G D P$} \\
\hline & $\begin{array}{c}\text { No. of } \\
\text { countries }\end{array}$ & $\begin{array}{c}\text { Mean of } \\
\text { growth } \\
\text { rates }\end{array}$ & $\begin{array}{c}\text { Mean of } \\
\text { standard } \\
\text { deviations }\end{array}$ & $\begin{array}{c}\text { No. of } \\
\text { countries }\end{array}$ & $\begin{array}{c}\text { Mean of } \\
\text { growth } \\
\text { rates }\end{array}$ & $\begin{array}{c}\text { Mean of } \\
\text { standard } \\
\text { deviations }\end{array}$ \\
\hline \multicolumn{7}{|l|}{ OECD countries } \\
\hline 1870-1913 & 15 & 0.0141 & 0.0415 & 21 & 0.0141 & 0.0373 \\
\hline 1914-47 & 15 & 0.0111 & 0.0871 & 21 & 0.0145 & 0.0885 \\
\hline 1948-2006 & 15 & 0.0264 & 0.0257 & 21 & 0.0287 & 0.0284 \\
\hline 1870-2006 & 15 & 0.0187 & 0.0538 & 21 & 0.0205 & 0.0544 \\
\hline \multicolumn{7}{|c|}{ Non-OECD countries } \\
\hline $1870-1913$ & 6 & 0.0135 & 0.0837 & 11 & 0.0159 & 0.0668 \\
\hline $1914-47$ & 6 & 0.0147 & 0.0886 & 11 & 0.0132 & 0.0704 \\
\hline 1948-2006 & 6 & 0.0264 & 0.0544 & 11 & 0.0257 & 0.0436 \\
\hline 1870-2006 & 6 & 0.0225 & 0.0750 & 11 & 0.0198 & 0.0606 \\
\hline \multicolumn{7}{|l|}{ All countries } \\
\hline $1870-1913$ & 21 & 0.0140 & 0.0536 & 32 & 0.0147 & 0.0475 \\
\hline $1914-47$ & 21 & 0.0121 & 0.0875 & 32 & 0.0140 & 0.0823 \\
\hline 1948-2006 & 21 & 0.0264 & 0.0339 & 32 & 0.0276 & 0.0336 \\
\hline 1870-2006 & 21 & 0.0196 & 0.0599 & 32 & 0.0202 & 0.0565 \\
\hline
\end{tabular}

Source: Authors' construction; for details on sources and procedures see the online appendix at www.economics. harvard.edu/faculty/barro/data_sets_barro.

a. $C$ represents real per capita personal consumer expenditure; GDP represents real per capita GDP. Samples are limited to countries from table 1 with complete data on growth rates from 1904 or earlier, so that each country has at least ten observations for 1870-1913. Averages are not weighted.

back as far as possible until 1870; that is, the first observation is for the growth rate from 1869 to 1870 .

Table 3 considers three subperiods: 1870-1913 (pre-World War I), 1914-47 (which includes the two world wars and the Great Depression of the early 1930s), and 1948-2006 (post-World War II). The table shows averages across the included countries of growth rates and standard deviations of growth rates. ${ }^{5}$ For the full period, 1870-2006, the average of the growth rates of $\mathrm{C}$ for twenty-one countries is 0.020 (that is, 2.0 percent a year), with an average standard deviation (s.d.) of 0.060. The average for fifteen OECD countries is 0.019 (s.d. $=0.054$ ), and that for six non-OECD countries is 0.022 (s.d. $=0.075$ ). For GDP, the average growth rate for thirty-two countries is 0.020 (average s.d. $=0.056$ ). The average for twentyone OECD countries is 0.020 (s.d. $=0.054$ ), and that for eleven non-OECD countries is 0.020 (s.d. $=0.061$ ).

5. In order to have at least ten years of coverage for the 1870-1913 subperiod, table 3 considers only countries with data going back at least to 1904 . 
Table 3 shows that the last subperiod, 1948-2006, has higher growth rates and lower standard deviations than the first subperiod, 1870-1913. For example, for GDP growth in the OECD countries, the reduction in the standard deviation-from 0.037 in 1870-1913 to 0.028 in 1948-2006-is the kind of change found by Christina Romer for the United States and plausibly attributed mainly to improved measurement of macroeconomic aggregates. ${ }^{6}$ However, the most striking difference across the subperiods involves the turbulence of the middle interval. For $\mathrm{C}$ growth in the OECD group, the average standard deviation for $1914-47$ is 0.087 , compared with 0.042 for 1870-1913 and 0.026 for 1948-2006. Similarly, for GDP growth in the OECD group, the average standard deviation for the middle interval is 0.088 , compared with 0.037 and 0.028 in the other two periods.

An important feature of the 1870-2006 samples is that they include realizations of disasters, notably those in the 1914-47 subperiod, which featured the two world wars and the Great Depression. These realizations create fat tails indicated by excess kurtosis and usually lead, thereby, to rejection in long samples of the hypothesis of normality for growth rates of $\mathrm{C}$ or GDP. ${ }^{7}$ For $\mathrm{C}$ growth the only case out of twenty-one in which normality is accepted (by a Jarque-Bera test) at the 5 percent level is the United States $(p=0.23)$. For GDP growth normality is accepted among thirty-two cases only for Iceland ( $p=0.07)$, Switzerland ( $p=0.15)$, Brazil $(p=0.05)$, and Uruguay $(p=0.51)$.

Appendix B presents long-term graphs of real per capita C and GDP for the twenty-four countries that have annual data on both variables from before 1914. In each case the vertical axis has a natural-log scale that ranges from 5.5 to 11.0 ( $\$ 245$ to $\$ 59,900$ in 2000 U.S. dollars). These graphs bring out the long-term trends and show the major economic contractions. Note that a movement by 0.1 along the vertical axis corresponds to a change in the level of per capita GDP or C of about 10 percent.

As examples, for Germany GDP and C fell during World War II, World War I, and the Great Depression of the 1930s. For France the dominant contraction was during World War II, with a lesser decline in World War I. For Spain the main adverse event was its civil war during the late 1930s. The United Kingdom shows declines in C during the two world wars; GDP did not fall during the wars, but it did during their aftermaths. In the United

\section{Romer (1986).}

7. The tendency for negative skewness-disasters rather than bonanzas-is less pronounced than we anticipated. Over the long samples, for $\mathrm{C}$ growth, eleven of twenty-one countries exhibit negative skewness, and for GDP growth, twenty-four of thirty-two exhibit negative skewness. 
States the main declines in $\mathrm{C}$ took place during the Great Depression of the early 1930s and in the early 1920s; GDP also fell at these times, as well as in the aftermath of World War II. An unusual case is the very strong behavior of U.S. GDP during World War II, while C remained fairly stable. The United States is also an outlier in the sense of passing the "ruler test"-a ruler placed along the pre-1914 data happens to lie along the observations post-1950. As noted by Timothy Cogley and by Barro, ${ }^{8}$ the United States is almost unique in displaying this apparent tendency for the GDP data to return to a fixed trend line. In other cases (even including Canada, which comes close) the fixed-trend hypothesis is rejected by the GDP data. The full dataset corresponding to the appendix figures and to the available time series for other countries is posted on the Internet. ${ }^{9}$

\section{Rates of Return}

Our study involves the interplay between macroeconomic variables, represented by consumer expenditure and GDP, and rates of return on various financial assets. It does not make a major contribution to the construction of long-term data on asset returns. Instead we rely mainly on existing information, primarily that provided by Global Financial Data. ${ }^{10}$ Table 4 shows the dates over which we have been able to assemble time series on real rates of return. In all cases we compute arithmetic real rates of return, using consumer price indexes to deflate the nominal-return indexes. As far as possible, the return indexes and CPIs apply to the end of each year.

Table 4 considers three types of assets: stocks, short-term bills (government treasury bills with maturity of three months or less and analogous claims such as deposits), and long-term government bonds (usually of tenyear maturity). For stocks some of the information comes from total-return indexes, which combine price changes and dividends. In other cases we estimated returns from stock-price indexes, using rough estimates of dividend yields. We hope eventually to obtain data from Elroy Dimson, Paul Marsh, and Mike Staunton to extend our stock-return data backward for at least Canada, Denmark, Italy, the Netherlands, Norway, Sweden, and Switzerland. ${ }^{11}$

Table 5 shows means and standard deviations of rates of return for countries with nearly continuous annual time series going back at least to
8. Cogley (1990, table 2); Barro (forthcoming).
9. See www.economics.harvard.edu/faculty/barro/data_sets_barro.
10. See Taylor (2005).
11. Dimson, Marsh, and Staunton (2008). 
Table 4. Starting Dates and Missing Values for Real Rates of Return ${ }^{a}$

\begin{tabular}{|c|c|c|c|c|}
\hline \multirow[b]{2}{*}{ Country } & \multicolumn{2}{|c|}{ Stocks } & \multirow[b]{2}{*}{ Bills } & \multirow[b]{2}{*}{ Bonds } \\
\hline & $\begin{array}{l}\text { Total } \\
\text { returns }\end{array}$ & $\begin{array}{c}\text { Stock } \\
\text { indexes }\end{array}$ & & \\
\hline \multicolumn{5}{|l|}{ OECD countries } \\
\hline Australia & 1883 & 1876 & $1862^{\mathrm{b}}$ & $1862^{\mathrm{b}}$ \\
\hline Austria & 1970 & $\begin{array}{c}1923 \\
{[1939-44]}\end{array}$ & $\begin{array}{c}1885^{\mathrm{b}} \\
{[1938-44]}\end{array}$ & 1946 \\
\hline Belgium & 1951 & $\begin{array}{l}1898[1914-18, \\
1940,1944-46]\end{array}$ & $\begin{array}{c}1849 \\
{[1945-46]}\end{array}$ & $\begin{array}{c}1836^{\mathrm{b}} \\
{[1945-46]}\end{array}$ \\
\hline Canada & 1934 & 1916 & $\begin{array}{c}1903 \\
{[1914-34]}\end{array}$ & $1880^{\mathrm{b}}$ \\
\hline Denmark & 1970 & 1915 & 1864 & 1822 \\
\hline Finland & 1962 & 1923 & $1915^{\mathrm{b}}$ & 1960 \\
\hline France & $\begin{array}{c}1896 \\
{[1940-41]}\end{array}$ & $\begin{array}{c}1857 \\
{[1940-41]}\end{array}$ & $1841^{\mathrm{b}}$ & $1841^{\mathrm{b}}$ \\
\hline Germany & $\begin{array}{c}1870 \\
{[1917-23]}\end{array}$ & 1841 & 1854 & 1924 \\
\hline Greece & 1977 & $\begin{array}{c}1929 \\
{[1941-52]}\end{array}$ & $\begin{array}{c}1915^{\mathrm{b}} \\
{[1944-45]}\end{array}$ & 1993 \\
\hline Iceland & 2003 & 1993 & $\begin{array}{c}1988 \\
{[2004-06]}\end{array}$ & $\begin{array}{c}1993 \\
{[2004-06]}\end{array}$ \\
\hline Italy & 1925 & 1906 & 1868 & 1862 \\
\hline Japan & 1921 & 1894 & 1883 & 1871 \\
\hline Netherlands & 1951 & $\begin{array}{c}1920 \\
{[1945-46]}\end{array}$ & $1881^{\mathrm{b}}$ & $1881^{\mathrm{b}}$ \\
\hline New Zealand & 1987 & 1927 & 1923 & 1926 \\
\hline Norway & 1970 & 1915 & 1819 & 1877 \\
\hline Portugal & 1989 & $\begin{array}{c}1932 \\
{[1975-77]}\end{array}$ & $1930^{\mathrm{b}}$ & 1976 \\
\hline Spain & 1941 & $\begin{array}{c}1875 \\
{[1936-40]}\end{array}$ & 1883 & 1941 \\
\hline Sweden & 1919 & 1902 & 1857 & 1922 \\
\hline Switzerland & 1967 & $\begin{array}{c}1911 \\
{[1914-16]}\end{array}$ & 1895 & 1916 \\
\hline United Kingdom ${ }^{c}$ & 1791 & 1791 & 1801 & 1791 \\
\hline United States & 1801 & 1801 & 1836 & 1801 \\
\hline Non-OECD countr & & & & \\
\hline Argentina & 1988 & $\begin{array}{c}1939 \\
{[1958-66]}\end{array}$ & 1978 & - \\
\hline Brazil & 1988 & 1955 & 1995 & - \\
\hline Chile & 1983 & 1895 & 1864 & - \\
\hline Colombia & 1988 & 1928 & 1986 & - \\
\hline India & 1988 & $\begin{array}{c}1921 \\
{[1926-27]}\end{array}$ & 1874 & $1874^{\mathrm{b}}$ \\
\hline Indonesia & 1988 & $\begin{array}{c}1925 \\
{[1940-77]}\end{array}$ & 1970 & - \\
\hline Malaysia & 1973 & 1974 & 1960 & $\begin{array}{c}1961 \\
\text { (continued) }\end{array}$ \\
\hline
\end{tabular}


Table 4. Starting Dates and Missing Values for Real Rates of Returna (Continued)

\begin{tabular}{lcccc}
\hline & \multicolumn{3}{c}{ Stocks } & \\
\cline { 2 - 4 } Country & $\begin{array}{c}\text { Total } \\
\text { returns }\end{array}$ & $\begin{array}{c}\text { Stock } \\
\text { indexes }\end{array}$ & Bills & Bonds \\
\hline Mexico & 1988 & 1930 & 1962 & 1995 \\
Peru & 1993 & 1927 & 1985 & - \\
Philippines & 1982 & 1953 & 1950 & 1997 \\
Singapore & 1970 & 1966 & 1960 & 1988 \\
South Africa & 1961 & 1911 & 1936 & 1896 \\
South Korea & 1963 & 1963 & 1951 & 1957 \\
Sri Lanka & 1993 & 1953 & 1951 & - \\
Taiwan & 1988 & {$[1975-84]$} & & 1990 \\
Turkey & 1987 & 1968 & 1962 & 1990 \\
Uruguay & - & 1987 & 1973 & 1996 \\
Venezuela & 1988 & - & - & - \\
\hline
\end{tabular}

Sources: Authors' calculations using data mostly from Global Financial Data; stock-price indexes for Japan 1893-1914 are from Fujino and Akiyama (1977); bills data for Colombia, Indonesia, and Peru are from the International Monetary Fund. In some cases consumer price index data are from sources other than Global Financial Data.

a. Years in brackets are years with missing data. Rates of return are computed on an arithmetic basis using end-of-year values of total-return indexes divided by consumer price indexes. Stock returns computed from stock-price indexes include rough estimates of dividend yields (or use actual dividend yields in some cases). Bill returns are for short-term government bills (maturity of three months or less) or, in some cases, for overnight rates, deposit rates, or central bank discount rates. Bond returns are typically for ten-year government bonds but sometimes for other maturities.

b. Starting date is limited by missing consumer price index data.

c. Data before 1790 are not used. Bond data are for consols up to 1932 and for ten-year government bonds thereafter.

d. Stock-price data are available starting in 1925, but estimates of dividend yields are unavailable.

e. January 1942 stock-price index is used to approximate year-end value for 1941 .

the 1920s. ${ }^{12}$ The first two data columns show stock and bill returns, where a common sample applies in each case to the two types of returns. The last two data columns show analogous information for bond and bill returns. We emphasize in the present study the comparison between stocks and bills - and, hence, the customary equity premium.

For the seventeen countries with matched stock and bill returns data, the mean real rates of return over long-term samples were 0.0814 for stocks and 0.0085 for bills. (For each country we used a common sample for stock and bill returns.) Thus, the average equity premium was 0.0729 . For the fifteen

12. The missing data for this group, involving two to five years each for six countries, are mainly during major wars, for which real rates of return on all three assets were probably sharply negative. This sample selection biases all measured rates of return upward, although the quantitative effect cannot be too large because of the small number of years involved. The effect on computed equity premia is likely to be even smaller. 


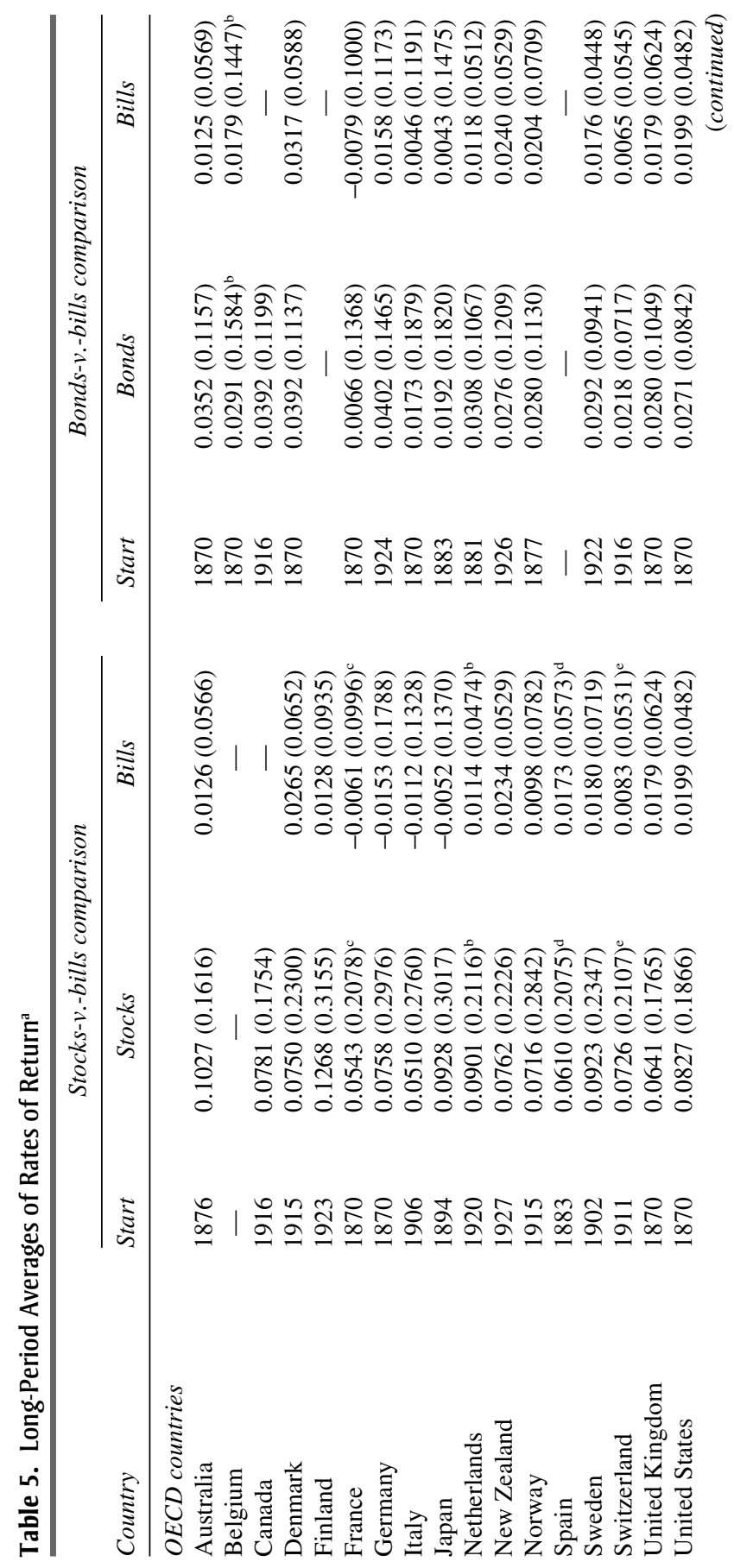




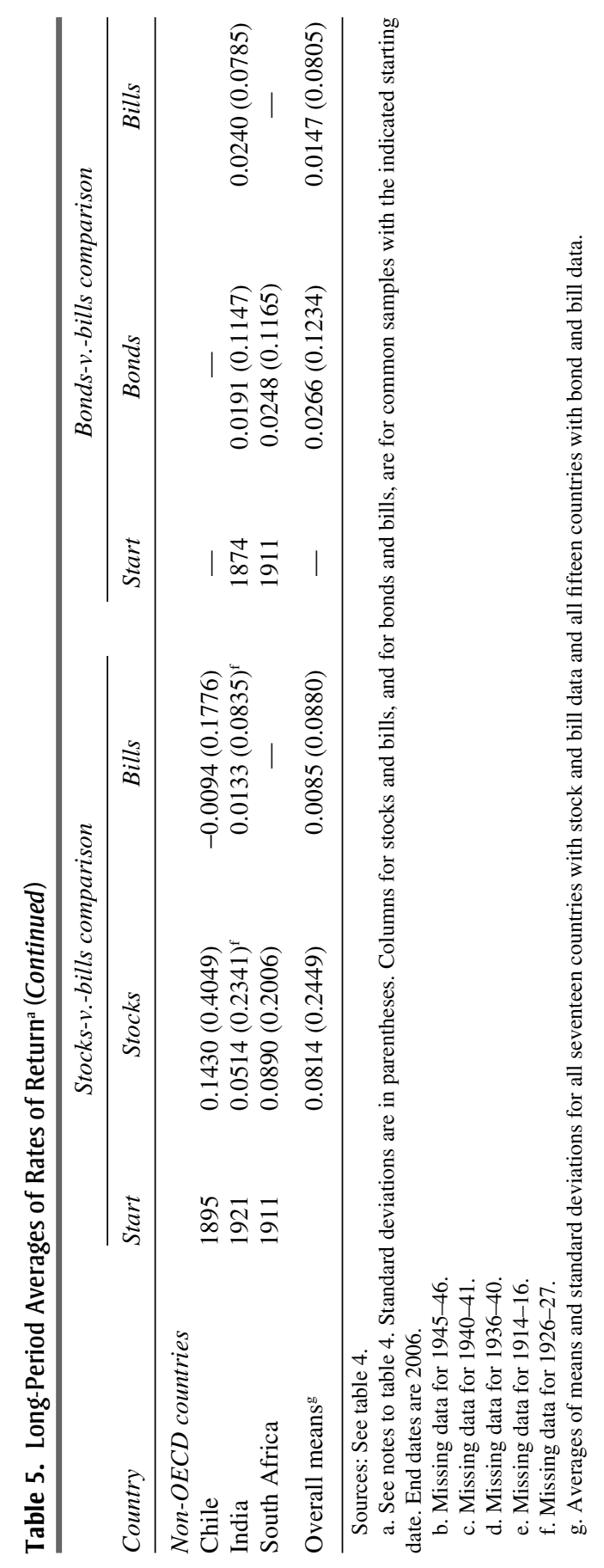


OECD countries in this sample, the average rates of return were 0.0793 for stocks and 0.0093 for bills, with an average equity premium of 0.0699 .

Since the stock returns refer to levered equity, the equity premium for unlevered equity would be smaller. For example, with a debt-equity ratio of one-half (roughly that for U.S. nonfinancial corporations in recent years), the predicted premium for unlevered equity would be $0.0729 / 1.5=$ 0.049 . Thus, we take as a challenge for the model to explain an unlevered equity premium of around 5 percent a year. This type of challenge is the one taken up long ago by Mehra and Prescott. ${ }^{13}$

The model should also be consistent with observed levels of rates of return, including an average real bill rate of less than 1 percent a year. However, in the model simulations we choose the rate of time preference, $\rho$, to accord with the observed average level of the real bill rate (taken as a rough estimate of a risk-free rate, although bills are not risk-free). The reasoning is that the main basis for assessing a plausible value of $\rho$ is to consider whether the implied levels of rates of return are sensible. Therefore, matching overall levels of rates of return does not provide a test of the model.

For the fifteen countries (fourteen of which belong to the OECD) with matched bond and bill returns data, the average long-term rate of return on bonds was 0.0266 , compared with 0.0147 for bills over common samples. Thus, the average bond-bill premium was 0.0119 . The present study does not address the bond-bill premium.

Table 5 also shows the familiar high annual standard deviation of stock returns, which averaged 0.245 for the seventeen countries with matched bill data ( 0.235 for the fifteen OECD countries). The corresponding average standard deviation for bill returns was 0.088 ( 0.082 for the fifteen OECD countries). Thus, bill returns exhibited substantial volatility but not nearly as great as that of stocks.

\section{Consumer Expenditure and GDP Disasters}

To isolate economic disasters for $\mathrm{C}$ and GDP, we first follow the procedure in Barro's 2006 paper by computing peak-to-trough fractional declines that exceed some threshold amount. ${ }^{14}$ The earlier study used a lower bound of 0.15 , but we broaden this limit here to 0.10 . The inclusion of contractions between 0.10 and 0.15 brings in many more events but has only moderate implications for explaining asset returns.

13. See Mehra and Prescott (1985).

14. Barro (2006). 
The peak-to-trough method for assessing the size of contractions is reasonable if growth rate shocks are independent and identically distributed (i.i.d.), so that level shocks are permanent. However, the method can be misleading when some shocks to levels are temporary. Later we modify the approach by using one-sided Hodrick-Prescott (HP) filters to attempt to gauge long-run, as opposed to transitory, economic contractions. In ongoing research with Emi Nakamura and Jón Steinsson, we are taking a formal statistical approach that uses the full time series for C and GDP for each country. This approach considers transitional probabilities for movements between normal and crisis regimes and allows for varying degrees of longterm effects of crises on levels of C and GDP.

The full results on measuring $\mathrm{C}$ crises are presented in table $\mathrm{C} 1$ in appendix $\mathrm{C}$ and summarized in table 6 . The coverage is twenty-one OECD countries (seventeen with enough data for our subsequent analysis) and fourteen non-OECD countries (seven in our later analysis). For GDP crises, shown in table $\mathrm{C} 2$ in appendix $\mathrm{C}$ and summarized in table 7, the coverage is twenty-one OECD countries (all used in our subsequent analysis) and eighteen non-OECD countries (fifteen in our later analysis). For the samples used later, the mean size of $\mathrm{C}$ contraction (95 events for 24 countries) was 21.9 percent, and the mean size of GDP contraction (152 events for 36 countries) was 20.7 percent.

To highlight some cases, the United States has been comparatively immune to crises, with $\mathrm{C}$ declines of 16 percent in 1921 (possibly influenced by the influenza epidemic of 1918-20) and 21 percent during the Great Depression in 1933. GDP declines were 10 percent in 1908 and 1914 (years affected by banking panics ${ }^{15}$ ), 12 percent in 1921, 29 percent in 1933, and 16 percent in 1947. The last contraction, likely precipitated by the post-World War II demobilization, did not exhibit a consumption decline. For the United Kingdom, the two C crises were during the world wars: 17 percent in both 1918 and 1943. There were no GDP disasters at these times, but GDP did contract after the two wars, by 19 percent in 1921 and 15 percent in 1947.

For France we found three war-related disasters for C: 16 percent in 1871 (Franco-Prussian War), 22 percent in 1915 (World War I), and 58 percent in 1943 (World War II). For GDP there were six contractions, the largest measuring 41 percent in 1944. For Germany there were four C crises: 42 percent in 1918 (World War I), 13 percent in 1923 (German hyperinflation), 12 percent in 1932 (Great Depression), and 41 percent in

15. See Cagan (1965, p. 138). 
Table 6. Summary of Consumer Expenditure Disasters by Event or Period and Country Group ${ }^{\mathrm{a}}$

\begin{tabular}{|c|c|c|c|}
\hline $\begin{array}{l}\text { Event or period } \\
\text { and country group }\end{array}$ & $\begin{array}{l}\text { No. of } \\
\text { events }\end{array}$ & $\begin{array}{l}\text { Average } \\
\text { fractional } \\
\text { decline } \\
\quad \text { in } C\end{array}$ & Declines in C by country \\
\hline Pre-1914 & 21 & 0.16 & \\
\hline OECD & 11 & 0.15 & $\begin{array}{l}\text { Canada, 0.15, 0.11; Finland, 0.10; } \\
\text { France, 0.16; Netherlands, 0.10; } \\
\text { Spain, 0.18; Switzerland, 0.19, } \\
0.22,0.14,0.14,0.16\end{array}$ \\
\hline Non-OECD & 10 & 0.16 & $\begin{array}{l}\text { Argentina, } 0.12,0.28,0.20,0.13 \text {, } \\
\quad 0.12 ; \text { Brazil } 0.15,0.16 \text {; Peru, } 0.12 \\
\text { Taiwan, } 0.22,0.13\end{array}$ \\
\hline World War I & 20 & 0.24 & \\
\hline OECD & 14 & 0.26 & $\begin{array}{l}\text { Australia, 0.24; Austria, 0.45; } \\
\text { Belgium, 0.45; Canada, 0.13; } \\
\text { Finland, 0.36; France, 0.22; } \\
\text { Germany, 0.42; Netherlands, 0.44; } \\
\text { Norway, 0.17; Portugal, 0.22; } \\
\text { Spain, 0.13; Sweden, 0.12; } \\
\text { Switzerland, 0.11; U.K., 0.17 }\end{array}$ \\
\hline Non-OECD & 6 & 0.18 & $\begin{array}{l}\text { Argentina, 0.17; Brazil, } 0.11 \text {; Chile, } \\
\text { 0.32; Malaysia, } 0.10 ; \text { Mexico, } \\
\text { 0.25; Singapore, } 0.14\end{array}$ \\
\hline $1920 \mathrm{~s}$ & 11 & 0.18 & \\
\hline OECD & 6 & 0.17 & $\begin{array}{l}\text { Canada, 0.20; Denmark, 0.24; } \\
\text { Germany, 0.13; Norway, 0.16; } \\
\text { Sweden, 0.13; U.S., } 0.16\end{array}$ \\
\hline Non-OECD & 5 & 0.20 & $\begin{array}{l}\text { Brazil, } 0.15 \text {; Chile, } 0.18 \text {; Malaysia, } \\
\text { 0.42; Mexico, 0.12; Singapore, } 0.13\end{array}$ \\
\hline Great Depression & 18 & 0.21 & \\
\hline OECD & 7 & 0.19 & $\begin{array}{l}\text { Australia, 0.23; Austria, 0.22; } \\
\text { Canada, 0.23; Finland, 0.20; } \\
\text { Germany, 0.12; Spain, 0.10; } \\
\text { United States, } 0.21\end{array}$ \\
\hline Non-OECD & 11 & 0.22 & $\begin{array}{l}\text { Argentina, 0.19; Brazil, 0.20; Chile, } \\
\text { 0.37; Colombia, 0.18; India, 0.22; } \\
\text { Malaysia, 0.26; Mexico, } 0.31 ; \\
\text { Peru, 0.14; Singapore, 0.10; } \\
\text { Turkey, 0.12; Venezuela, } 0.31\end{array}$ \\
\hline Spanish civil war & 2 & 0.29 & \\
\hline OECD & 2 & 0.29 & Portugal, 0.12; Spain, 0.46 \\
\hline Non-OECD & 0 & NA & \\
\hline Late $1930 \mathrm{~s}$ & 1 & 0.11 & \\
\hline OECD & 0 & NA & \\
\hline Non-OECD & 1 & 0.11 & Venezuela, 0.11 \\
\hline
\end{tabular}


Table 6. Summary of Consumer Expenditure Disasters by Event or Period and Country Group ${ }^{\mathrm{a}}$ (Continued)

\begin{tabular}{|c|c|c|c|}
\hline $\begin{array}{l}\text { Event or period } \\
\text { and country group }\end{array}$ & $\begin{array}{l}\text { No. of } \\
\text { events }\end{array}$ & $\begin{array}{l}\text { Average } \\
\text { fractional } \\
\text { decline } \\
\quad \text { in } C\end{array}$ & Declines in $C$ by country \\
\hline World War II & 23 & 0.34 & \\
\hline OECD & 17 & 0.34 & $\begin{array}{l}\text { Australia, 0.30; Austria, 0.44; } \\
\text { Belgium, 0.53; Denmark, 0.26; } \\
\text { Finland, 0.25; France, 0.58; } \\
\text { Germany, 0.41; Greece, 0.64; } \\
\text { Italy, 0.29; Japan, 0.64; Nether- } \\
\text { lands, 0.54; Norway, 0.10; } \\
\text { Portugal, 0.10; Spain, 0.14; } \\
\text { Sweden, 0.18; Switzerland, 0.17; } \\
\text { U.K., 0.17 }\end{array}$ \\
\hline Non-OECD & 6 & 0.34 & $\begin{array}{l}\text { Colombia, 0.23; India, } 0.13 \text {; } \\
\text { Malaysia, 0.34; South Korea, 0.39; } \\
\text { Taiwan, 0.68; Turkey, } 0.30\end{array}$ \\
\hline Post-World War II & 38 & 0.18 & \\
\hline OECD & 9 & 0.14 & $\begin{array}{l}\text { Denmark, 0.14; Finland, 0.14; } \\
\text { Greece, 0.11; Iceland, 0.25, 0.12, } \\
\text { 0.11, 0.18; Portugal. 0.10; } \\
\text { Spain, } 0.13\end{array}$ \\
\hline Non-OECD & 29 & 0.19 & $\begin{array}{l}\text { Argentina, } 0.10,0.10,0.16,0.25 ; \\
\text { Brazil, 0.16; Chile, 0.14, 0.40, } \\
\text { 0.33; Colombia, 0.10; India; } 0.18 ; \\
\text { Malaysia, 0.12, 0.14, 0.12; } \\
\text { Mexico, 0.16, 0.11; Peru, 0.18, } \\
\text { 0.30; Singapore, 0.16, 0.12; South } \\
\text { Korea, 0.37, 0.14; Turkey, 0.11; } \\
\text { Uruguay, 0.10, 0.27, 0.22; } \\
\text { Venezuela, 0.20, 0.22, } 0.32,0.15\end{array}$ \\
\hline
\end{tabular}

Source: Authors' construction; for details on sources and procedures see the online appendix at www. economics.harvard.edu/faculty/barro/data_sets_barro.

a. Calculations are based on appendix table $\mathrm{C} 1$. Data for war periods include noncombatants. C represents real per capita personal consumer expenditure.

1945 (World War II). There were also four crises indicated by GDP, the largest a remarkable 74 percent in 1946, reflecting the economic collapse late in World War II.

Many other countries suffered sharp contractions during World War II. For example, C declined in Belgium by 53 percent up to 1942, in Greece by 64 percent up to 1944, in Japan by 64 percent up to 1945, in the Netherlands by 55 percent up to 1944, and in Taiwan by 68 percent up to 1945 . Other noteworthy cases for $\mathrm{C}$ were the contractions in Spain during its 
Table 7. Summary of GDP Disasters by Event or Period and Country Group ${ }^{\mathrm{a}}$

\begin{tabular}{|c|c|c|c|}
\hline $\begin{array}{l}\text { Period and } \\
\text { country group }\end{array}$ & $\begin{array}{l}\text { No. of } \\
\text { events }\end{array}$ & $\begin{array}{c}\text { Average } \\
\text { fractional } \\
\text { decline } \\
\text { in GDP }\end{array}$ & $\begin{array}{l}\text { Fractional decline in } \\
\text { GDP by country }\end{array}$ \\
\hline Pre-1914 & 45 & 0.16 & Australia, 0.27; Canada, 0.12; \\
\hline OECD & 19 & 0.15 & $\begin{array}{l}\text { Finland, 0.12; France, 0.10, 0.10, } \\
\text { 0.13; Greece, 0.11, 0.15, 0.23, } \\
\text { 0.15, 0.14, 0.42; Iceland, 0.12; } \\
\text { New Zealand, 0.17, 0.11; } \\
\text { Spain, 0.12; Switzerland, 0.16; } \\
\text { U.S., 0.10, 0.10 }\end{array}$ \\
\hline Non-OECD & 26 & 0.17 & $\begin{array}{l}\text { Argentina, } 0.19,0.22,0.15 \\
\text { Brazi, } 0.10,0.26,0.14 ; \\
\text { Chile, 0.11; India, 0.15, 0.10; } \\
\text { Malaysia, 0.10; Philippines, 0.16; } \\
\text { Singapore, 0.21, 0.34; } \\
\text { Sri Lanka, 0.16, 0.14; Taiwan, } \\
\text { 0.21, 0.11; Uruguay, 0.27, 0.15, } \\
\text { 0.14, 0.20, 0.16, 0.12; } \\
\text { Venezuela, 0.24, 0.22, } 0.13\end{array}$ \\
\hline World War I & 27 & 0.21 & Australia, 0.12; Austria, 0.38; \\
\hline OECD & 14 & 0.24 & $\begin{array}{l}\text { Belgium, 0.48; Denmark, 0.16; } \\
\text { Finland, 0.35; France, 0.29; } \\
\text { Germany, 0.36; Greece, 0.18; } \\
\text { Iceland, 0.22; Netherlands, 0.26; } \\
\text { New Zealand, 0.11; Norway, 0.15; } \\
\text { Sweden, 0.15; Switzerland, } 0.19\end{array}$ \\
\hline Non-OECD & 13 & 0.17 & $\begin{array}{l}\text { Argentina, 0.29; Chile, } 0.10,0.13 ; \\
\text { India, 0.15; Mexico, 0.12; } \\
\text { Philippines, 0.12; Singapore, 0.17, } \\
\text { 0.24; South Africa, 0.23; South } \\
\text { Korea, 0.11; Sri Lanka, 0.14; } \\
\text { Uruguay, 0.28; Venezuela, 0.17 }\end{array}$ \\
\hline $1920 \mathrm{~s}$ & 15 & 0.18 & \\
\hline OECD & 11 & 0.16 & $\begin{array}{l}\text { Canada, 0.30; Germany, 0.14; } \\
\text { Greece, 0.24; Iceland, 0.16; Italy, } \\
\text { 0.22; New Zealand, 0.12; Norway, } \\
\text { 0.11; Portugal, 0.11; Sweden, 0.11; } \\
\text { U.K., 0.19; U.S., 0.12 }\end{array}$ \\
\hline Non-OECD & 4 & 0.22 & $\begin{array}{l}\text { Singapore, } 0.39 \text {; South Africa, 0.24; } \\
\text { Turkey, 0.13; Uruguay, } 0.14\end{array}$ \\
\hline Great Depression & 22 & 0.22 & \\
\hline OECD & 9 & 0.21 & $\begin{array}{l}\text { Australia, 0.22; Austria, 0.24; } \\
\text { Belgium, 0.12; Canada, 0.35; } \\
\text { France, 0.19; Germany, 0.28; } \\
\text { Netherlands, 0.13; Spain, 0.10; } \\
\text { U.S., 0.29 }\end{array}$ \\
\hline
\end{tabular}


Table 7. Summary of GDP Disasters by Event or Period and Country Group ${ }^{\mathrm{a}}$ (Continued)

\begin{tabular}{|c|c|c|c|}
\hline $\begin{array}{l}\text { Average } \\
\text { Period and } \\
\text { country group }\end{array}$ & $\begin{array}{l}\text { No. of } \\
\text { events }\end{array}$ & $\begin{array}{c}\text { fractional } \\
\text { decline } \\
\text { in GDP }\end{array}$ & $\begin{array}{l}\text { Fractional decline in } \\
\text { GDP by country }\end{array}$ \\
\hline Non-OECD & 13 & 0.23 & $\begin{array}{c}\text { Argentina, 0.20; Brazil, 0.20; Chile, } \\
\text { 0.36; Indonesia, 0.11; Malaysia, } \\
\text { 0.19; Mexico, 0.31; Peru, 0.26; } \\
\text { Philippines, 0.13; Singapore, } 0.41 \\
\text { Sri Lanka, 0.15; Turkey, 0.12; } \\
\text { Uruguay, 0.37; Venezuela, } 0.16\end{array}$ \\
\hline Spanish civil war & 2 & 0.23 & \\
\hline OECD & 2 & 0.23 & Portugal, 0.15; Spain, 0.31 \\
\hline Non-OECD & 0 & NA & \\
\hline Late $1930 \mathrm{~s}$ & 3 & 0.12 & \\
\hline OECD & 0 & NA & \\
\hline Non-OECD & 3 & 0.12 & $\begin{array}{l}\text { Malaysia, } 0.12 \text {; Singapore, } 0.15 \\
\quad \text { South Korea, } 0.10\end{array}$ \\
\hline World War II & 25 & 0.36 & \\
\hline OECD & 14 & 0.37 & $\begin{array}{l}\text { Australia, 0.14; Austria, 0.59; } \\
\text { Belgium, 0.45; Denmark, 0.24; } \\
\text { Finland, 0.10; France, 0.41; } \\
\text { Germany, 0.74; Greece, 0.66; } \\
\text { Italy, 0.41; Japan, 0.50; } \\
\text { Netherlands, 0.52; Norway, } 0.19 \text {; } \\
\text { Sweden, 0.10; Switzerland, } 0.13\end{array}$ \\
\hline Non-OECD & 11 & 0.35 & $\begin{array}{l}\text { India, } 0.12 \text {; Indonesia, } 0.54 \text {; } \\
\text { Malaysia, 0.24, 0.36; Philippines, } \\
\text { 0.57; South Korea, 0.48; Sri } \\
\text { Lanka, 0.21; Taiwan, 0.66; } \\
\text { Turkey, 0.40; Uruguay, 0.14; } \\
\text { Venezuela, 0.16 }\end{array}$ \\
\hline Post-World War II & 30 & 0.17 & \\
\hline OECD & 6 & 0.13 & $\begin{array}{l}\text { Finland, 0.12; Iceland, 0.14; New } \\
\text { Zealand, 0.12, 0.10; U.K., 0.15; } \\
\text { U.S., } 0.16\end{array}$ \\
\hline Non-OECD & 24 & 0.17 & $\begin{array}{l}\text { Argentina, 0.10, 0.11, 0.14, 0.22; } \\
\text { Brazil, 0.11; Chile, 0.24, 0.18; } \\
\text { Indonesia, 0.16; Mexico, 0.13; } \\
\text { Peru, 0.10, 0.14, 0.32; } \\
\text { Philippines, 0.19; Singapore, } 0.34, \\
\text { 0.11; South Africa, 0.11, 0.10; } \\
\text { South Korea, 0.15; Uruguay, 0.12, } \\
\text { 0.24, 0.19; Venezuela, 0.15, } \\
\text { 0.30, } 0.26\end{array}$ \\
\hline
\end{tabular}

Source: Authors' construction; for details on sources and procedures see the online appendix at www. economics.harvard.edu/faculty/barro/data_sets_barro.

a. Calculations are based on appendix table $\mathrm{C} 2$. Data for war periods include noncombatants. 
civil war, by 46 percent up to 1937, and in Chile during the 1970s military takeover period, by 40 percent up to 1976 .

U.S. studies often focus on the severity of the Great Depression; in fact, some researchers gauge disaster probabilities entirely from this single event. ${ }^{16}$ One reason for this focus on the Depression is that the United States happened to do well economically during the two world wars, which were major economic disasters for much of the rest of the world, including many OECD countries. However, even if one's concern is limited to forecasting U.S. disasters or studying disaster probabilities as perceived by investors in the United States, it seems plausible that the global experienceparticularly of comparable OECD countries-would provide a great deal of information. Our perspective is that U.S. prospects can be gauged much better by consulting the global experience, rather than overweighting the United States' own history, for which the few observed disasters are likely to be dominated by luck.

In a global context, at least since 1870, the most serious economic disaster in terms of incidence and severity of declines in C and GDP was World War II. This event was followed in terms of economic impact by World War I and the Great Depression of the early 1930s-two events with similar overall consequences.

Among the thirty-five countries included for $\mathrm{C}$ in appendix table $\mathrm{C}$, table 6 shows that World War II had twenty-three crises with an average size of 34 percent. (This table includes noncombatant experiences as part of the war periods.) World War I had twenty crises with an average size of 24 percent, and the Great Depression had eighteen crises with an average size of 21 percent. The 1920s had another eleven events, including eight with troughs in 1920-21, with an average size of 18 percent. As already mentioned, the contractions at the start of the 1920s may reflect the influenza epidemic of $1918-20 .{ }^{17}$ We also found twenty-one pre-1914 events (for a truncated sample because of missing data) with an average size of 16 percent.

The post-World War II period was remarkably calm for the OECD countries: only nine consumption crises were found, four of which were in Iceland (relating in part to shocks to the fishing industry). The largest crisis outside of Iceland was 14 percent for Finland in the early 1990s (a crisis thought to originate from the changed economic relationship with the former Soviet Union). However, economic crises have not disappeared from

16. See, for example, Chatterjee and Corbae (2007) and Cogley and Sargent (2008).

17. Ursúa (2008). 
the world, as is clear from the twenty-nine non-OECD consumption events with an average size of 19 percent. The disasters here include the Latin American debt crisis of the early 1980s, the Asian financial crisis of the late 1990s, and the difficulties in 2001-02 in Argentina related to the collapse of that country's currency board.

Table 7 provides a roughly similar picture for crises gauged by per capita GDP. For the thirty-nine countries included in appendix table C2, World War II had twenty-five events with an average size of 36 percent. World War I had twenty-seven events with a mean size of 21 percent, and the Great Depression had twenty-two cases with an average size of 22 percent. The 1920s had another fifteen events - ten of them with troughs in 1920-21with a mean size of 18 percent. The pre-1914 period (where GDP events were more plentiful than those for consumer expenditure) showed fortyfive events, with an average size of 16 percent. The post-World War II period featured only six events for the OECD; the largest were the postWorld War II aftermaths for the United States (16 percent) and the United Kingdom (15 percent). Again, the situation was much less calm outside of the OECD: twenty-four events with an average size of 17 percent.

\section{Consumer Durables}

The consumption concept that enters into asset pricing equations would be closer to real consumer expenditure on nondurable goods and services (subsequently referred to as nondurables) than to overall consumer expenditure. That is, one might want to exclude durables outlays or, better yet, include an estimate of rental income on the slowly moving stock of durables. However, except for the OECD countries after World War II (which had few crises), we typically lack the data to divide personal consumer expenditure into durables and nondurables expenditure.

Table $\mathrm{C} 3$ in appendix $\mathrm{C}$ shows the twenty-eight cases among the $\mathrm{C}$ disasters from table $\mathrm{C} 1$ for which we have been able to locate data that permit a breakdown in the decline in real personal consumer expenditure into durables and nondurables. Twenty of these cases are in our main sample of ninety-five $\mathrm{C}$ crises. Not surprisingly, the proportionate decreases in durables expenditure were typically much larger than those in nondurables. On average for the twenty-eight crises, the proportionate fall in per capita $\mathrm{C}$ was 18.3 percent, that in durables was 39.6 percent, and that in nondurables was 15.1 percent. Thus, a substitution of nondurables expenditure for overall consumer expenditure would reduce the mean size of contraction among the twenty-eight cases by about 3 percentage points. 
The main reason that the adjustment for durables has only a moderate, though significant, impact is that the share of nominal durables expenditure in total personal consumer expenditure is usually not large, averaging 8.0 percent at the peaks and 5.8 percent at the troughs for the twenty-eight cases considered in table C $3 .{ }^{18}$ As an extreme example, for the United Kingdom during World War II, the measured durables share fell to only 2.3 percent in 1943 (with household spending on automobiles falling to near zero). But since the durables share of nominal personal consumer expenditure at the peak in 1938 was only 4.9 percent, the adjustment was still only 2.5 percentage points; that is, the proportionate fall in nondurables was 14.4 percent, compared with 16.9 percent for all personal consumer expenditure.

The average durables adjustment of 3 percentage points likely overstates the overall effects. The reason is that we are systematically missing data on the breakdown between durables and nondurables for the larger crises: the mean contraction in $\mathrm{C}$ for the twenty-eight cases in table $\mathrm{C} 3$ was 18.3 percent, compared with a mean of 21.9 percent for the ninety-five $\mathrm{C}$ contractions used in our subsequent analysis. The largest $\mathrm{C}$ contractions in table $\mathrm{C} 3$ are 46 percent for Spain in 1935-37, 36 percent for Finland in 1913-18, 33 percent for Chile in 1981-85, and 32 percent for Venezuela in 1982-89.

Consider an arithmetic formula for the magnitude of the proportionate change in nondurables - this formula applies when durables and nondurables are both declining, with the size of the fractional decline in durables exceeding that in nondurables:

$$
\left|\frac{\Delta N D}{N D}\right|=\left|\frac{\Delta C}{C}\right|-\left(\frac{D}{N D}\right) \cdot\left[\left|\frac{\Delta D}{D}\right|-\left|\frac{\Delta C}{C}\right|\right],
$$

where $C$ is total consumer expenditure, $D$ is durables expenditure, and $N D$ is nondurables expenditure. We have already noted that the size of the adjustment is limited by the modest share of durables in total expenditurethis effect comes through the term $D / N D$.

An additional effect in equation 1 is that as we consider contractions with larger magnitude for $\Delta C / C$, the difference between the size of $\Delta D / D$ and that of $\triangle C / C$ must, at least eventually, get smaller. For example, the largest possible magnitude of $\Delta D / D$ is one. In this extreme situation, the amount of adjustment in switching to nondurables has to fall as the size of $\triangle C / C$ gets larger (with the adjustment approaching zero as the size of

18. The change in the nominal share of durables from peak to trough depends partly on the relative growth rates of real durables and nondurables and partly on the relative growth rates of prices of durables versus nondurables. 
$\triangle C / C$ approaches one). This reasoning suggests that the durables adjustment would tend to be less important (in percentage points) for the larger crises - and these are the ones that matter most for replicating the equity premium in our later analysis. We do see this pattern in appendix table C3: for Spain in 1935-37 the adjustment is from 46.1 percent to 45.0 percent; for Finland in 1913-18 the adjustment is from 36.0 percent to 35.3 percent; and for Venezuela in 1982-89 the adjustment is from 32.0 percent to 29.9 percent. However, for Chile in 1981-85 the adjustment is much larger, from 32.7 percent to 17.9 percent.

In any event, we lack information in most cases on the breakdown of personal consumer expenditure into durables and nondurables. Although we may add a few cases, we will not be able to go much beyond the coverage shown in appendix table $\mathrm{C} 3$. Therefore, we apply the rest of our analysis to crises gauged by personal consumer expenditure, $\mathrm{C}$, in appendix table $\mathrm{C} 1$, as well as to crises measured by GDP in appendix table $\mathrm{C} 2$.

\section{Consumer Expenditure and GDP Disasters Compared}

Table 8 matches $\mathrm{C}$ and GDP disasters for countries with full data (seventeen OECD and seven non-OECD). We match the $\mathrm{C}$ and GDP contractions in appendix tables $\mathrm{C} 1$ and $\mathrm{C} 2$, respectively, by trough years-either the same or a nearby year. In some cases a contraction by 0.10 or more in $\mathrm{C}$ or GDP does not pair up with a decline of at least 0.10 in the other variable (in which case the decline in the other variable does not appear in appendix table $\mathrm{C} 1$ or $\mathrm{C} 2$ ). In those cases we enter in table 8 the actual decline in the other variable (where, for a few cases, a negative value means that the variable increased).

Macroeconomists, particularly those familiar with U.S. data, tend to believe that proportionate contractions in consumer expenditure during recessions are typically smaller than those in GDP. Partly this view comes from the Great Depression, and the numbers in appendix tables $\mathrm{C} 1$ and $\mathrm{C} 2$ bear out this perspective: as an example, the proportionate declines in the United States up to 1933 were 21 percent for C and 29 percent for GDP. The idea that $\mathrm{C}$ is relatively more stable than GDP reflects also the general patterns in post-World War II macroeconomic fluctuations, including those in the United States. Since 1954, the standard deviation of the cyclical part of U.S. real GDP was 1.6 percent, compared with 1.2 percent for real consumer expenditure. ${ }^{19}$ The main counterpart of the smoother behavior

19. Barro (2008, p. 185). 


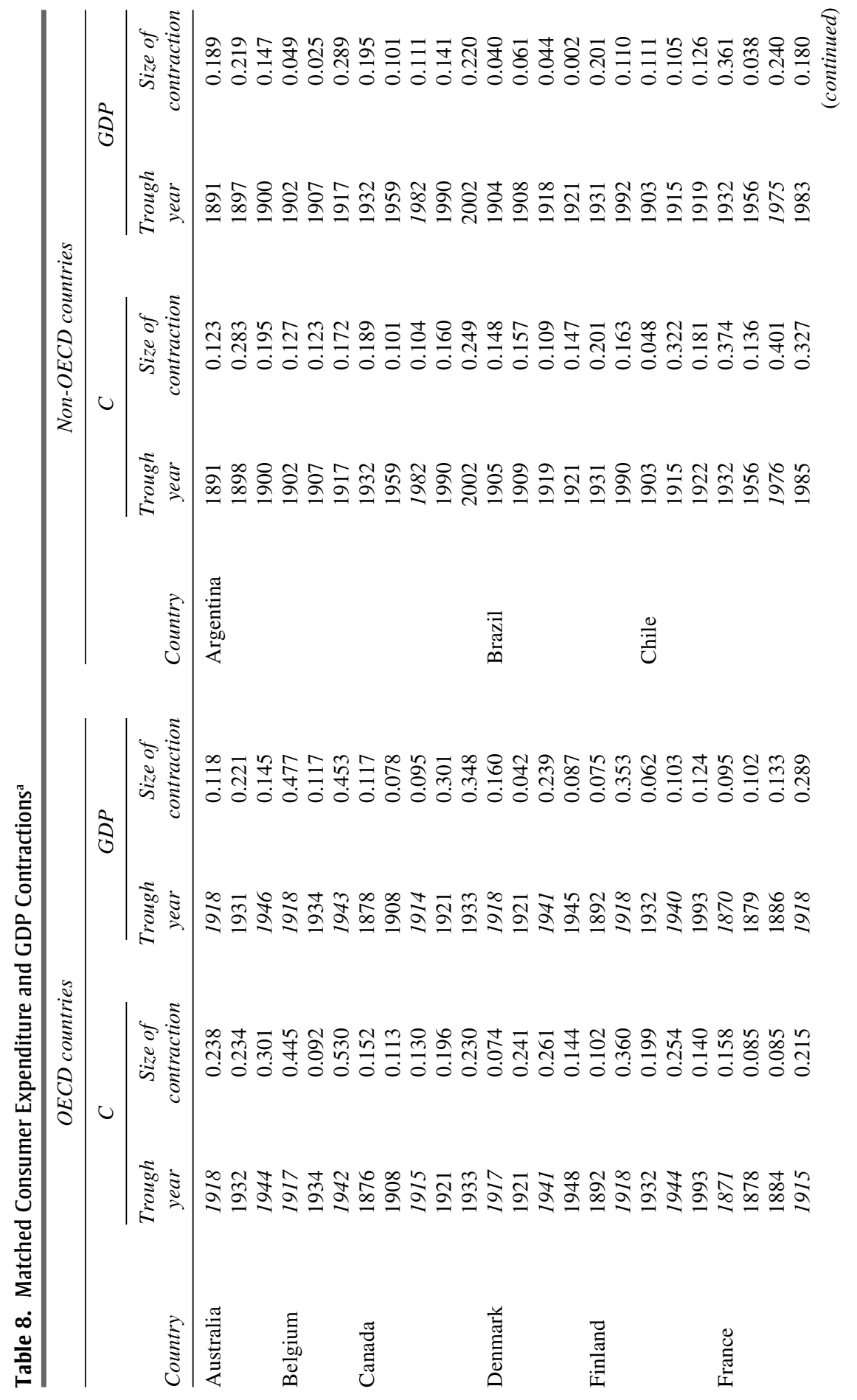




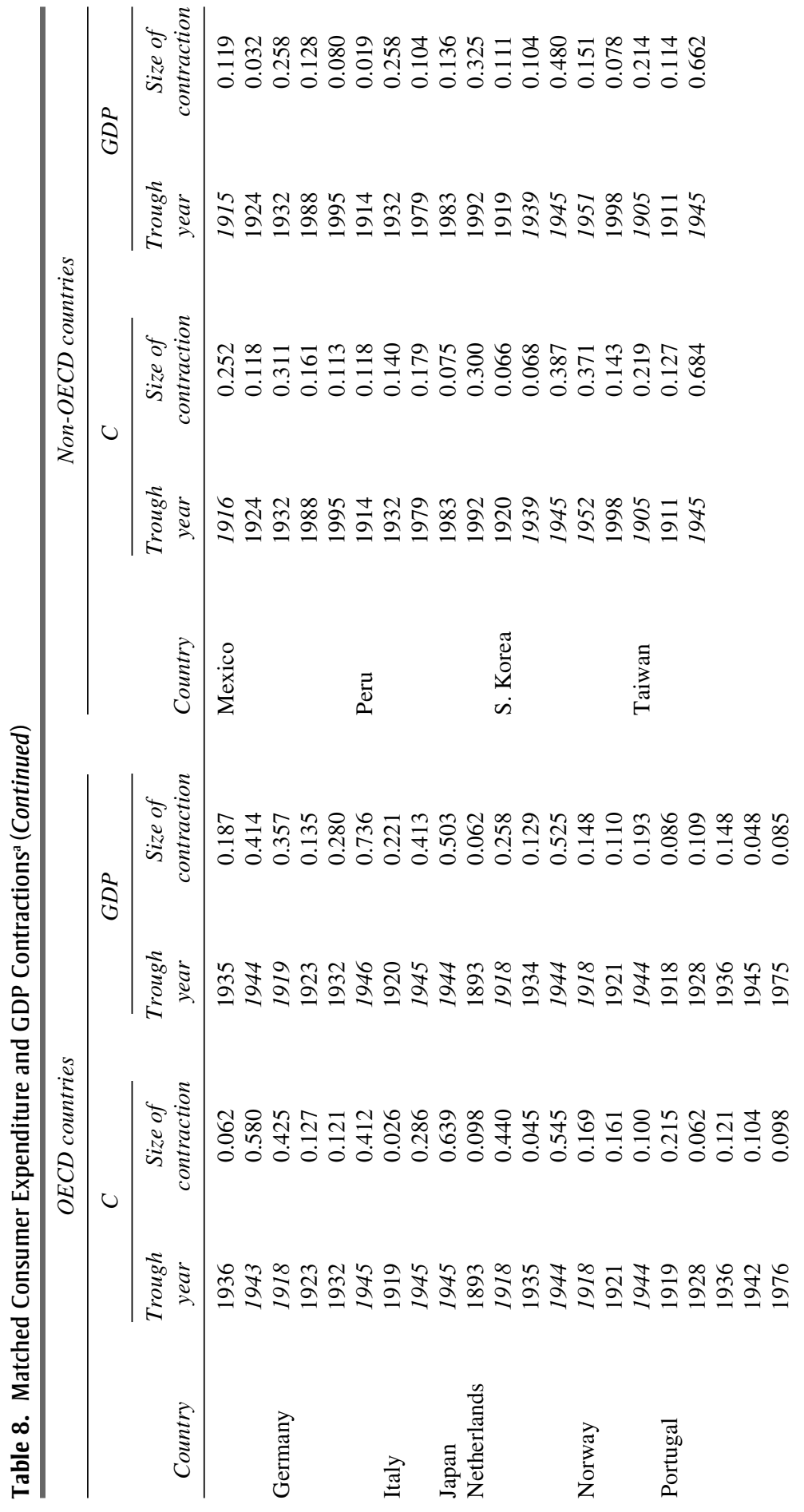




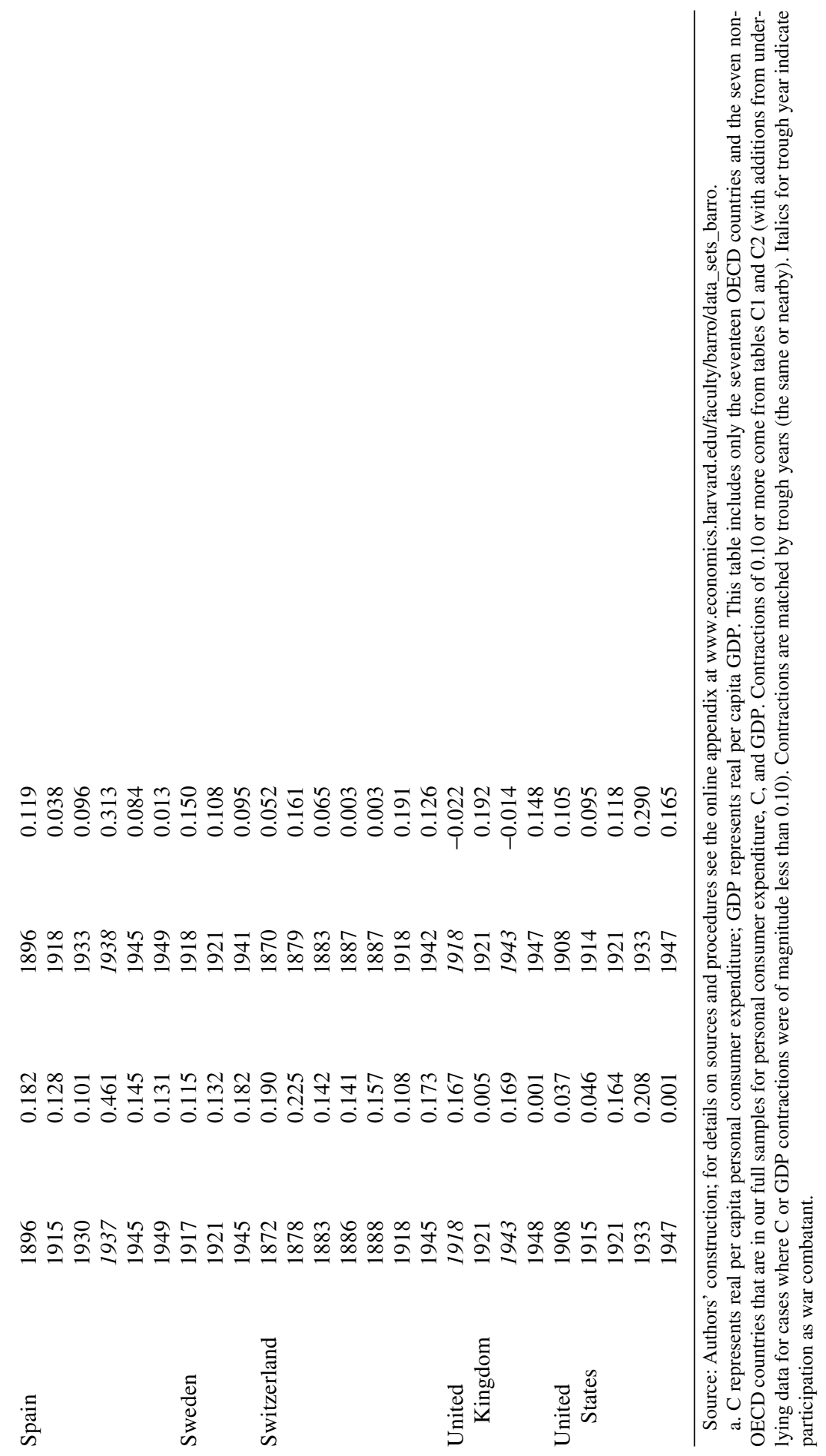


of $\mathrm{C}$ than of GDP was sharply fluctuating investment. That is, the steep declines in investment during U.S. recessions, including the Great Depression, partly buffered the decreases in consumer expenditure. ${ }^{20}$ This buffering could also apply, in principle, to the current account balance; that is, a procyclical current account would moderate fluctuations in consumer spending (and investment) relative to those in GDP. However, in the post1954 period, the ratio of the U.S. current account balance to GDP was actually weakly countercyclical. ${ }^{21}$

From a theoretical standpoint (and despite the validity of the permanentincome hypothesis), it is not inevitable that consumption would fluctuate proportionately by less than GDP. These patterns depend on whether the underlying macroeconomic shocks impinge more on investment demand or on desired saving. This balance depends, in turn, on the permanence of the shocks and whether they operate primarily as income effects or as shifts to the productivity of capital. In a simple AK model with i.i.d. shocks to the growth rate of productivity, $A$, consumption and GDP would always have the same proportionate variations.

An important consideration during wartime is the sharp increase in government purchases for the military. This expansion of government spending decreases $C$ (and investment) for a given GDP. ${ }^{22}$ In our data many of the $\mathrm{C}$ and GDP crises - and a disproportionate share of the larger crisesfeature these wartime expansions of government spending. In such circumstances $\mathrm{C}$ would tend to decline proportionately by more than GDP.

Table 9, based on the matching of contractions shown in table 8 , covers 112 contractions overall, 70 for OECD countries and 42 for non-OECD countries. Of the 112 contractions, 31 featured participation of the country as a war combatant and $81 \mathrm{did}$ not (the label "nonwartime" in table 9 includes noncombatants during major wars). In the eighty-one nonwartime cases, the average proportionate decrease in $\mathrm{C}$ was slightly greater than that in GDP: 14.6 percent versus 12.9 percent (12.6 percent versus 12.4 percent for the OECD countries). In the thirty-one wartime cases, the margin was greater: 31.8 percent versus 27.2 percent (32.0 percent versus 27.6 percent for the OECD countries).

20. This pattern is stronger for consumption measured by expenditure on nondurables and services, that is, when expenditures on consumer durables are grouped with investment.

21. Barro (2008, p. 429).

22. The declines in consumption and investment could be moderated by falls in the current account balance. However, the option of borrowing from abroad tends to be severely limited during a global conflict. Moreover, even in localized conflicts, combatants are likely to be cut off from international borrowing. 
Table 9. Means and Relative Timing of Matched Consumer Expenditure and GDP Contractions ${ }^{\mathrm{a}}$

\begin{tabular}{|c|c|c|c|c|c|}
\hline \multirow[b]{2}{*}{ Events } & \multirow[b]{2}{*}{$\begin{array}{c}\text { Mean C } \\
\text { contraction }\end{array}$} & \multirow[b]{2}{*}{$\begin{array}{l}\text { Mean GDP } \\
\text { contraction }\end{array}$} & \multicolumn{3}{|c|}{ Trough of $C$ contraction occurred } \\
\hline & & & $\begin{array}{l}\text { In same year as } \\
\text { GDP contraction }\end{array}$ & $\begin{array}{l}\text { Before GDP } \\
\text { contraction }\end{array}$ & $\begin{array}{l}\text { After GDP } \\
\text { contraction }\end{array}$ \\
\hline \multicolumn{6}{|l|}{ OECD countries } \\
\hline All (70 contractions) & 0.190 & 0.174 & 35 & 19 & 16 \\
\hline Wartime (23) & 0.320 & 0.276 & 10 & 9 & 4 \\
\hline Nonwartime (47) & 0.126 & 0.124 & 25 & 10 & 12 \\
\hline \multicolumn{6}{|l|}{ Non-OECD countries } \\
\hline All (42 contractions) & 0.199 & 0.159 & 31 & 1 & 10 \\
\hline Wartime (8) & 0.311 & 0.260 & 5 & 0 & 3 \\
\hline Nonwartime (34) & 0.173 & 0.135 & 26 & 1 & 7 \\
\hline \multicolumn{6}{|l|}{ Full sample } \\
\hline All (112 contractions) & 0.194 & 0.168 & 66 & 20 & 26 \\
\hline Wartime (31) & 0.318 & 0.272 & 15 & 9 & 7 \\
\hline Nonwartime (81) & 0.146 & 0.129 & 51 & 11 & 19 \\
\hline
\end{tabular}

Source: Authors' construction; for details on sources and procedures see the online appendix at www.economics. harvard.edu/faculty/barro/data_sets_barro.

a. Means and timing are for the matched contractions listed in table 8.

In terms of timing patterns, table 9 shows for the full sample of 112 crises that 66 have the same trough years for C and GDP. The trough year for $\mathrm{C}$ comes later in twenty-six cases, whereas that for GDP comes later in twenty cases. Thus, at least in the annual data, there is no clear pattern as to whether C or GDP reaches its trough first during crises. If we consider only wartime cases, fifteen of the thirty-one have the same trough year, whereas $\mathrm{C}$ reaches its trough later in seven and GDP reaches its trough later in nine. Thus, there is also no clear result on the timing pattern during wars.

One concern is that the apparent excess of the average size of $\mathrm{C}$ contractions over GDP contractions might reflect greater measurement error in the $\mathrm{C}$ data. In future formal statistical analysis of the C and GDP time series, we will allow for measurement error that might differ across countries, over time, and between the C and GDP data. For now we can get some idea about the role of measurement error by redoing the analysis using trend values of $\log (\mathrm{C})$ and $\log (\mathrm{GDP})$ calculated from HP filters. We use a conventional smoothing parameter for annual data of 100. Unlike in the standard setup, we use one-sided filters; that is, we consider only current and past values at each point in time when estimating "trends." (This procedure avoids the implication that people knew in advance of a coming destructive war or depression, so that they knew that a major decline in 
trend $\mathrm{C}$ or GDP was about to happen.) Instead of computing proportionate peak-to-trough decreases in C or GDP during crises, we calculate here the proportionate peak-to-trough decreases in the HP trend values. This procedure downplays short-lived contractions and tends to count only the more persistent declines. It also tends to filter out downturns that are merely a response to a previous upward blip in C or GDP. Most important in the present context, the HP filter tends to eliminate "crises" that reflect mainly temporary measurement error in C and GDP.

The HP filtering procedure substantially reduces the estimated number of disasters, from 95 to 43 for $\mathrm{C}$ and from 152 to 70 for GDP. The full results are presented in tables $\mathrm{C} 4$ and $\mathrm{C} 5$ in appendix $\mathrm{C}$. We matched the $\mathrm{C}$ and GDP crises, as before, and found thirty nonwartime pairs (seventeen in OECD countries and thirteen in non-OECD countries) and twenty-three wartime pairs (nineteen in OECD countries and four in non-OECD countries), the wartime pairs indicated by italics in tables $\mathrm{C} 4$ and $\mathrm{C} 5$. In the nonwartime sample, the average size of $\mathrm{C}$ decline was 12.0 percent, compared with 14.0 percent for GDP (8.8 percent and 13.4 percent, respectively, for the OECD countries). In the wartime sample, the mean size of $\mathrm{C}$ decline was 28.9 percent, compared with 23.8 percent for GDP (27.4 percent and 21.7 percent, respectively, for the OECD countries). Thus, the HP-filtered data generate wartime patterns that are similar to those found before: the average $\mathrm{C}$ decline was larger than that for GDP. However, the findings for nonwartime samples are reversed, with the average $\mathrm{C}$ decline smaller than that for GDP. Thus, overall, the main robust finding is that $\mathrm{C}$ tends to fall proportionately more than GDP during wartime crises. The relative magnitude of decline during nonwartime crises is less clear.

\section{Disaster Probability and the Frequency Distribution of Disaster Sizes}

This section considers the sample of countries with essentially complete annual time series since before 1914. We use twenty-four countries (including seventeen OECD countries) on per capita consumer expenditure, $\mathrm{C}$, and thirty-six countries (including twenty-one OECD countries) on per capita GDP. ${ }^{23}$ For the $\mathrm{C}$ sample of twenty-four countries, we isolated ninety-five disasters (appendix table $\mathrm{C} 1$ ). The top panel of figure 1

23. We include Greece and the Philippines in the GDP sample. Although GDP data are missing for Greece in 1944 and for the Philippines in 1941-45, we can compute the peak-totrough GDP declines during World War II in each case: 66 percent for Greece from 1939 to 1942 and 57 percent for the Philippines from 1939 to 1946. 
Figure 1. Distributions of Consumer Expenditure Disasters by Size and Duration ${ }^{\mathrm{a}}$

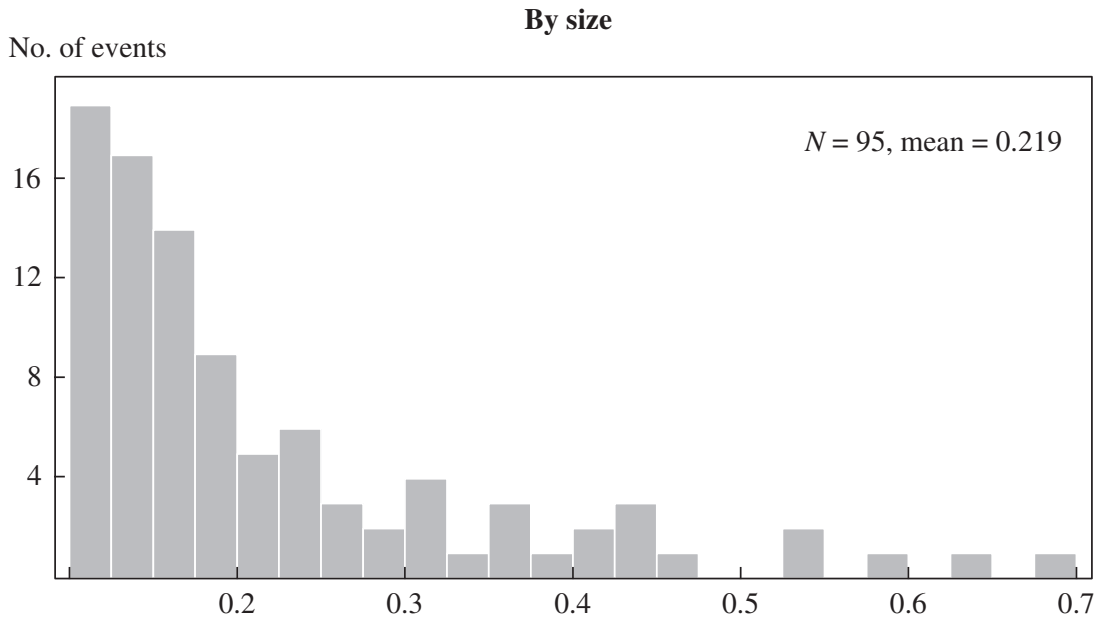

Cumulative fractional decline in real personal consumer expenditure per capita

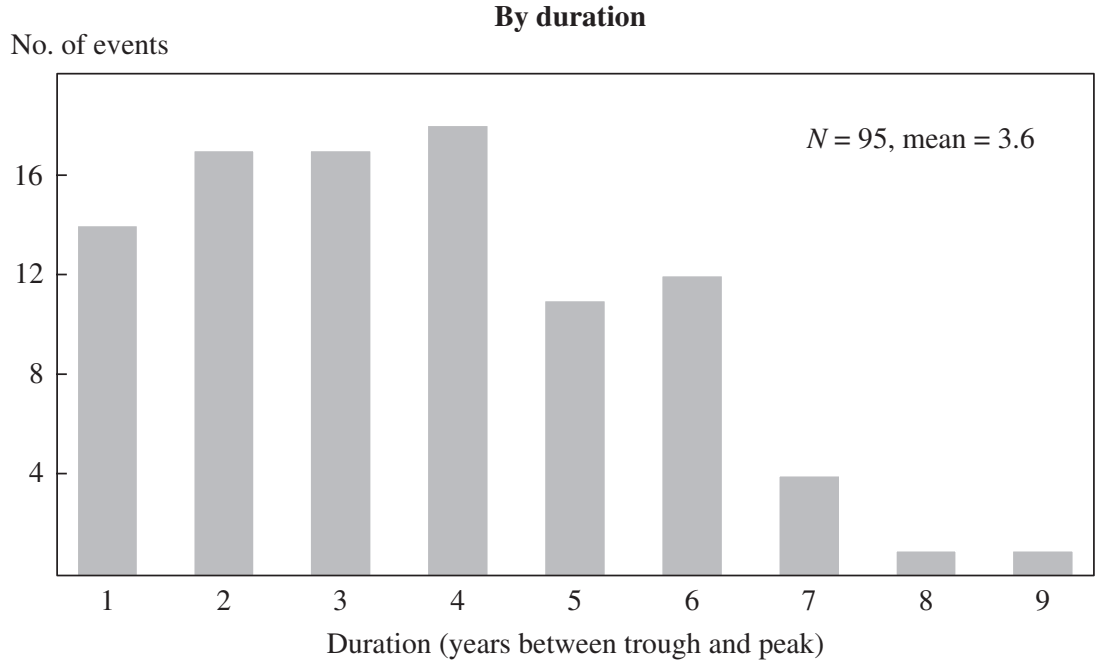

Source: Authors' construction; for details on sources and procedures see the online appendix at www.economics.harvard.edu/faculty/barro/data_sets_barro.

a. The sample is our main sample of ninety-five personal consumption expenditure disasters from appendix table $\mathrm{C} 1$. 
plots the frequency distribution of these $\mathrm{C}$ declines. The bottom panel shows the frequency distribution of the duration of these disasters (gauged, in each case, by the number of years from "peak" to "trough"). The average size was 22 percent, and the average duration was 3.6 years. For the GDP sample of thirty-six countries, we found 152 disasters (appendix table $\mathrm{C} 2$ ). The top panel of figure 2 plots the frequency distribution of these GDP declines, and the bottom panel shows the frequency distribution of the disaster durations. The average size was 21 percent, and the average duration was 3.5 years. Appendix figures D1 and D2 show the frequency distribution graphs for C and GDP corresponding to the HP-filtered data. The mean disaster sizes are very similar to the nonfiltered cases (22 percent for GDP and 23 percent for C), but average durations are longer because of the smoothing procedure (6.4 years for GDP and 6.3 years for $\mathrm{C}$ ).

In our subsequent simulation of a model of the equity premium, using the disaster data to calibrate the model, the results depend mainly on the probability of disaster, $p$, and the frequency distribution of the proportionate disaster size, $b$. With substantial risk aversion, the key aspect of the size distribution is not so much the mean of $b$ but, rather, the fatness of the tails, that is, the likelihood of extremely large disasters.

Suppose that there are two states, normalcy and disaster. With probability $p$ per year (taken here to be constant over time and across countries), the economy shifts from normalcy to disaster. With another probability $\pi$ per year (also constant over time and across countries), the economy shifts from disaster to normalcy. As mentioned before, we found 95 disasters for $\mathrm{C}$ and 152 for GDP. Also as noted before, we measured disaster years by the interval between peak and trough for each event. This calculation yields 343 disaster years for $\mathrm{C}$ and 530 disaster years for GDP. The total number of annual observations is 2,963 for $\mathrm{C}$ and 4,653 for GDP. Therefore, the number of normalcy years is 2,620 for $\mathrm{C}$ and 4,123 for GDP. We estimate $p$ as the ratio of the number of disasters to the number of normal years. This calculation yields $p=0.0363$ for $\mathrm{C}$ and 0.0369 for GDP. ${ }^{24} \mathrm{We}$ estimate $\pi$ as the ratio of the number of disasters (all of which eventually ended) to the number of disaster years. This computation gives $\pi=0.277$ for $\mathrm{C}$ and 0.287 for GDP. Therefore, whether we gauge by $\mathrm{C}$ or by GDP, we can think of disasters as starting with a probability of around 3.6 percent a year and ending with a probability of about 28 percent a year.

24. The main reason that these disaster probabilities exceed those in Barro (2006) is the inclusion of disaster sizes between 0.10 and 0.15 . If we consider only disasters of 0.15 or greater, the probabilities are $p=0.0218$ for $\mathrm{C}$ and 0.0192 for GDP. 
Figure 2. Distributions of GDP Disasters by Size and Duration ${ }^{\mathrm{a}}$
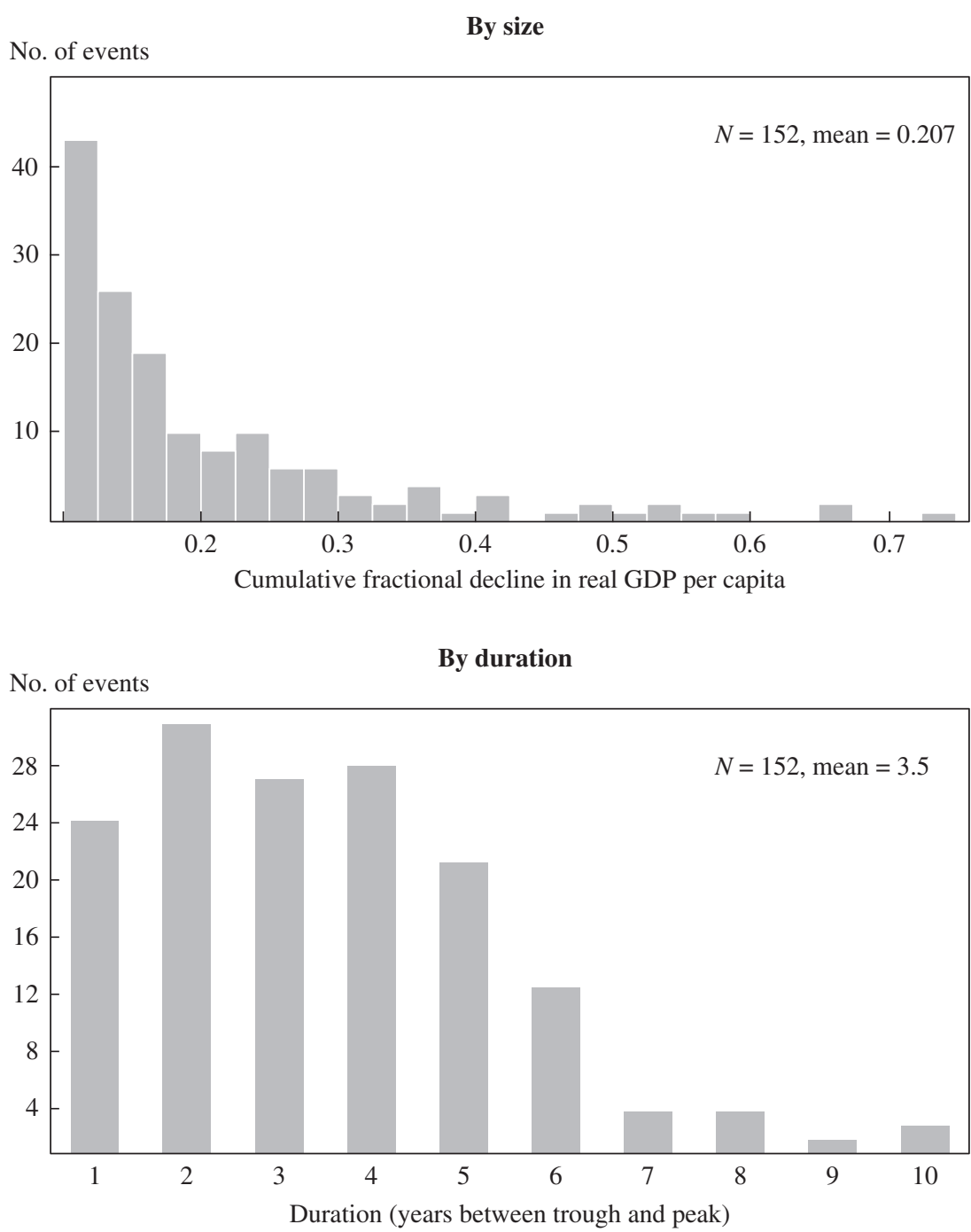

Source: Authors' construction; for details on sources and procedures see the online appendix at www.economics.harvard.edu/faculty/barro/data_sets_barro.

a. The sample is our main sample of 152 GDP disasters from appendix table C2. 
The frequency distributions for disaster size, $b$, shown for C and GDP, respectively, in the upper panels of figures 1 and 2, turn out to be well approximated by Pareto or power-law forms. These representations have been found to apply to an array of economic and physical phenomena, including amounts of stock-price changes and sizes of cities and firms. ${ }^{25}$ We plan to work out the application of power-law distributions to disaster sizes in future research.

\section{A Lucas-Tree Model of Rates of Return}

The estimates of $p$ and the $b$ distribution can be matched with rates of return determined in a representative-agent Lucas-tree setting. ${ }^{26}$ Our theoretical framework, summarized briefly here, follows that in a forthcoming paper by Barro, which extends his 2006 paper to use the Epstein-Zin-Weil (EZW) form of consumer preferences. ${ }^{27}$ That is, we allow for two distinct preference parameters: $\gamma$, the coefficient of relative risk aversion, and $\theta$, the reciprocal of the intertemporal elasticity of substitution (IES).

We set up the model, for convenience, in terms of discrete periods. However, the formulas derived later apply as the length of the period approaches zero. The log of real GDP evolves exogenously as a random walk with drift:

$$
\log \left(Y_{t+1}\right)=\log \left(Y_{t}\right)+g+u_{t+1}+v_{t+1}
$$

The first random term, $u_{t+1}$, is i.i.d. normal with mean zero and variance $\sigma^{2}$. This term reflects "normal" economic fluctuations due, for example, to productivity shocks. The parameter $g \geq 0$ is a constant that reflects exogenous productivity growth. Population is constant, so $Y_{t}$ represents per capita GDP as well as the level of GDP.

The second random term, $v_{t+1}$, picks up rare disasters, as in Rietz's earlier work and Barro's 2006 paper. ${ }^{28}$ In these rare events, output and consumption jump down sharply. The probability of a disaster is the constant $p \geq 0$ per unit of time. In a disaster, output and consumption contract by the fraction $b$, where $0<b<1$. The distribution of $v_{t+1}$ is given by

25. See Mandelbrot (1963), Fama (1965), and Gabaix (1999).

26. Lucas (1978).

27. Epstein and Zin (1989); Weil (1990).

28. Rietz (1988); Barro (2006). 


$$
\begin{aligned}
& \text { probability } 1-p: v_{t+1}=0 \\
& \text { probability } p: v_{t+1}=\log (1-b) .
\end{aligned}
$$

The disaster size, $b$, follows some probability distribution, which we gauge by the empirical densities shown in figures 1 and 2 .

In the baseline Lucas-tree setting - a closed economy with no investment and no government purchases - the representative agent's consumption, $C_{t}$, equals output, $Y_{t}{ }^{29}$ Given the processes that generate $u_{t+1}$ and $v_{t+1}$, the expected growth rate of $C_{t}$ and $Y_{t}$, denoted by $g^{*}$, is given by

$$
g^{*}=g+(1 / 2) \sigma^{2}-p \cdot \mathrm{E}(b),
$$

where $\mathrm{E}(b)$ is the expected value of $b$. (Note that we have allowed for disasters but not for "bonanzas.")

A key simplification, which allows for closed-form solutions, is that the shocks $u_{t+1}$ and $v_{t+1}$ in equation 2 are i.i.d.; that is, they represent permanent effects on the level of output, rather than transitory disturbances to this level. An important part of our ongoing research is to reassess this i.i.d. assumption, in particular to allow for transitory effects from disasters, such as wars and financial crises. (Another important extension, needed to match the observed volatility of stock prices and rates of return, is to allow for time variation in the uncertainty parameters, particularly the disaster probability, $p$.)

In general, EZW preferences do not yield closed-form solutions for asset pricing equations. However, Barro shows that with i.i.d. shocks (as in the present model), the first-order optimizing conditions generate asset pricing equations of familiar form: ${ }^{30}$

$$
C_{t}^{-\gamma}=\left(\frac{1}{1+\rho^{*}}\right) \cdot \mathrm{E}_{t}\left(R_{t} \cdot C_{t+1}^{-\gamma}\right),
$$

where $R_{t}$ is the one-period gross return on any asset. This specification differs from the standard power-utility model $(\gamma=\theta)$ in that, first, the exponent on consumption is the negative of the coefficient of relative risk aversion,

29. We can readily incorporate wartime-related government purchases, $G_{t}$, which do not substitute for $C_{t}$ in household utility but do create a wedge between $Y_{t}$ and $C_{t}$. In this case an increase in $G_{t}$ amounts to a decrease in productivity. Results on asset returns are similar in an AK model with endogenous investment and stochastic (i.i.d.) depreciation shocks; see Barro (forthcoming). In this setting, a disaster amounts to a large-scale destruction of Lucas trees.

30. Barro (forthcoming). 
$\gamma\left(\right.$ not $\theta$ ), and second, the effective rate of time preference, $\rho^{*}$, differs from the usual rate of time preference, $\rho$, when $\gamma \neq \theta$. The formula for $\rho^{*}$ is

$$
\begin{aligned}
\rho^{*}= & \rho-(\gamma-\theta) \cdot\left\{g^{*}-(1 / 2) \cdot \gamma \sigma^{2}-\left(\frac{p}{\gamma-1}\right)\right. \\
& \left.\cdot\left[\mathrm{E}(1-b)^{1-\gamma}-1-(\gamma-1) \cdot \mathrm{E}(b)\right]\right\},
\end{aligned}
$$

where $\mathrm{E}$ is the expectations operator and $g^{*}$ is the expected growth rate given in equation 3 .

The formulas for the expected rate of return on equity (unlevered claims to Lucas trees), $r^{e}$, and the risk-free rate, $r^{f}$, can be derived from equation 4 , given the process that generates $Y_{t}$ and $C_{t}$ in equation 2 . The results are

$$
\begin{aligned}
r^{e}= & \rho^{*}+\gamma g^{*}-(1 / 2) \cdot \gamma \cdot(\gamma-1) \cdot \sigma^{2} \\
& -p \cdot\left[\mathrm{E}(1-b)^{1-\gamma}-1-(\gamma-1) \cdot \mathrm{E}(b)\right] \\
r^{f}= & \rho^{*}+\gamma g^{*}-(1 / 2) \cdot \gamma \cdot(\gamma+1) \cdot \sigma^{2} \\
& -p \cdot\left[\mathrm{E}(1-b)^{-\gamma}-1-\gamma \cdot \mathrm{E}(b)\right] .
\end{aligned}
$$

Hence, the equity premium can be expressed as

$$
r^{e}-r^{f}=\gamma \sigma^{2}+p \cdot \mathrm{E}\left\{b \cdot\left[(1-b)^{-\gamma}-1\right]\right\},
$$

which depends only on $\gamma$ and the uncertainty parameters $(\sigma, p$, and the distribution of $b$ ). The first term, $\gamma \sigma^{2}$, is negligible and corresponds to the nodisaster equity premium of Mehra and Prescott. ${ }^{31}$ The second term brings in disasters and is proportional to the disaster probability, $p$. The disaster size, $b$, enters as the expectation of the product of $b$ (the proportionate decline in consumption) and the proportionate excess of the "marginal utility of consumption" 32 in a disaster state, $\left[(1-b)^{-\gamma}-1\right]$. This second term tends to be large.

The formulas for rates of return and the equity premium in equations 6 through 8 depend on a number of assumptions. The baseline model assumes that property rights in assets are perfectly maintained; in particular, there

31. Mehra and Prescott (1985).

32. This interpretation would be precise for power utility $(\gamma=\theta)$. 
are no possibilities for default on stocks or risk-free claims. The analysis can be extended to allow for partial defaults during crises. ${ }^{33}$ Aside from formal repudiation of claims, default can involve erosion of the real value of nominal claims through surprise jumps in the price level. This type of default tends to apply to government bills and bonds (which are typically denominated in nominal terms), rather than stocks. If one interprets the "risk-free" claim as a government bill, then a higher probability of default on bills, conditional on a crisis, lowers the equity premium in a revised version of equation 8 .

The model also neglects government rationing of consumption during crises, notably wars. Rationing can be viewed as a tax on consumption in crisis states. The more effective the system, in the sense of precluding black markets, the higher the effective tax rate on consumption beyond some rationed quantity; thus, a fully enforced rationing system has an infinite tax rate at the margin. (In practice, the situation is complicated because the rationing and hence the tax are likely to be temporary, lapsing once the crisis is over.) Rationing can be viewed as a form of partial default on assets, as above, but one that applies equally to gross returns on stocks and bills. Therefore, although rationing tends to lower the equity premium in an extended version of equation 8 , the effects are weaker than those from crisis-contingent defaults that apply only to bills.

Another issue for empirical implementation is that the model does not deal with the duration of disaster states; a disaster is a jump that takes place in one period, which amounts to an instant of time. Our research with Nakamura and Steinsson will deal explicitly with the time evolution of the economy during disaster states. For present purposes we assume that the important aspect of a disaster is the cumulative amount of contraction, $b$, which we gauge empirically by the numbers shown for $\mathrm{C}$ and GDP, respectively, in appendix tables $\mathrm{C} 1$ and $\mathrm{C} 2$. That is, we assume that, for a given cumulative decline, the implications for the equity premium do not depend a great deal on whether this decline occurs in an instant or, more realistically, is spread out over time.

To illustrate our assumption, figure 3 depicts two possible time paths for the $\log$ of C. Each case has two normalcy intervals, denoted A and B. These paths reflect growth at 0.025 per year and (different) realizations of normal shocks with a standard deviation, $\sigma$, of 0.02 per year-these parameters apply in our subsequent simulations. In each case a single disaster event with a cumulative fractional decline in $\mathrm{C}$ by 0.4 happens to occur 
Figure 3. Paths of Consumption with Different Durations of Crises ${ }^{\mathrm{a}}$

Case 1

$\log$ of $\mathrm{C}$

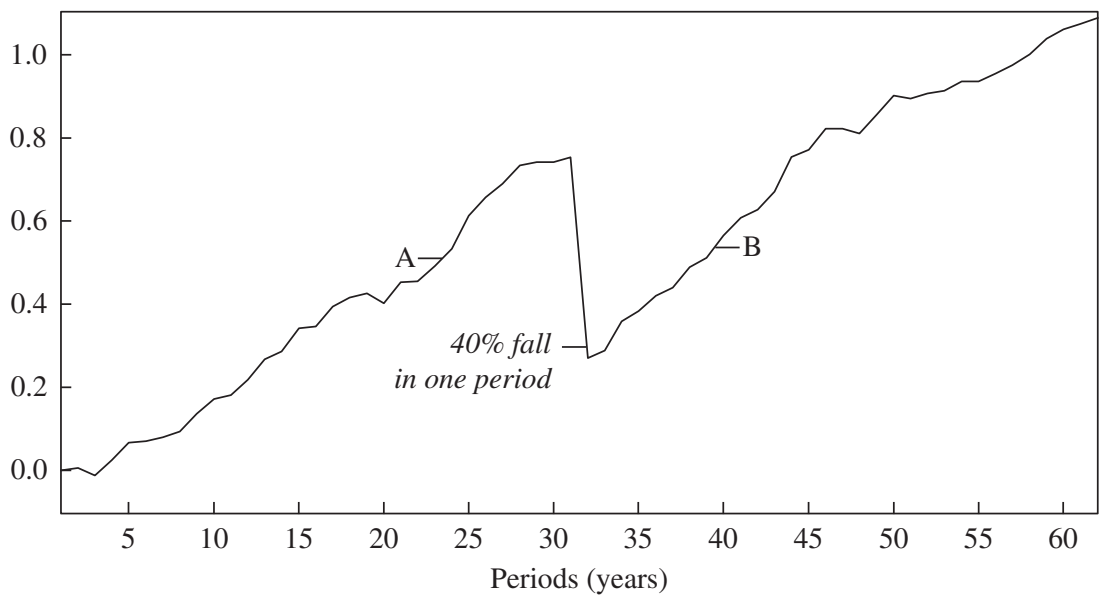

Case 2

Log of C

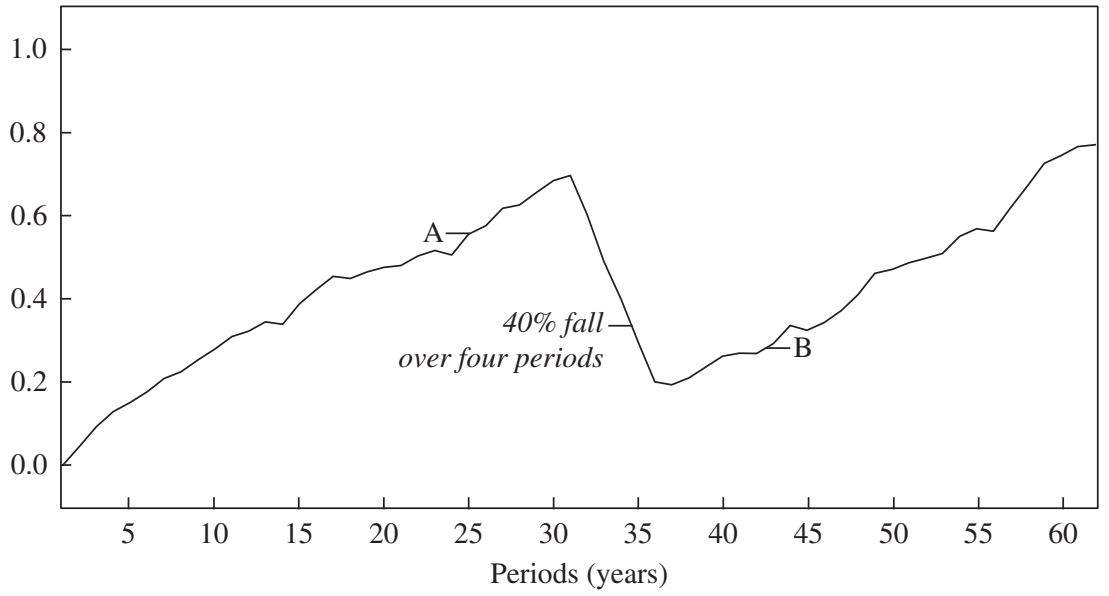

Source: Authors' calculations.

a. In case 1 a crisis entails a 40 percent decline in C over one period. In case 2 a crisis entails a 40 percent decline in $\mathrm{C}$ stretched over four periods. The normalcy periods (A and B in each panel) are generated by assuming mean growth of 0.025 per year with normally distributed shocks that have a standard deviation of 0.02 per year. The paths shown, meant only to be illustrative, reflect different realizations of random numbers in each case. 
in the middle of the sample. We are unsure at present how to model disaster states that last for more than an instant. The mean growth rate is likely to be much lower than normal, and the volatility is likely to be much higher than normal. In figure 3 the only difference between the two cases is that the fractional decline by 0.4 for the disaster in case 1 occurs over one period (which could be one year or one second), whereas that in case 2 stretches over four periods. The graphs assume, unrealistically, that crises have the usual amount of volatility-that is, normal shocks with $\sigma=0.02$ per year.

Our key assumption is that the determination of expected rates of return during normalcy periods (A and B in the two panels of figure 3) is roughly the same whether disasters look like case 1 or case 2 . This conclusion holds in an extension of the model pursued in Barro's 2006 paper, ${ }^{34}$ which assessed the effects of variations in the period length $T$. (This extension was feasible in a model with i.i.d. growth shocks.) In that setting $T$ represents the fixed duration of a disaster. Variations in $T$ between zero and 5 years did not have much impact on the implied equity premium (measured per year).

In practice, the normalcy rates of return would not be exactly the same in cases 1 and 2 of figure 3 . For example, case 2 implies low, perhaps negative short-term risk-free rates during crises and, therefore, capital gains on longer-term risk-free bonds when a crisis starts. This pattern has implications for the term structure of risk-free rates during normal times. However, a different specification-one where disasters entail higher than usual chances of default on bonds-predicts capital losses, rather than gains, on longer-term bonds when a crisis occurs. Because of this ambiguity, we are unable at this stage to go beyond our assumption that cases 1 and 2 are approximately the same for the equity premium.

\section{Simulating the Lucas-Tree Model}

We now simulate the Lucas-tree model by viewing the Euler condition in equation 4 as applying to a representative agent at the country level. That is, we neglect the implications of imperfect markets and heterogeneous individuals within countries. However, we also assume that markets are not sufficiently complete internationally for equation 4 to apply to the representative agent in the world. In future work we will assess how the analysis applies to multiple-country regions, rather than country by country.

In applying equation 4 to the determination of each country's asset returns, we neglect any implications from international trade in goods and

34. Barro (2006, section V). 
assets; that is, we effectively treat each country as a closed economy. With this perspective, we can view each country-period observation as providing independent information about the relationship between macroeconomic shocks and asset returns. In particular, this independence may be approximately right despite the clear common international dimensions of crises-most obviously from wars but also from financial crises, disease epidemics, and natural resource shocks.

We apply the full historical information on disaster probability and sizes to the simulation at each point in time. Thus, we implicitly assume that the underlying parameters are fixed over time and across countries and are known from the outset to the representative agent in each country. We therefore neglect learning about disaster parameters. ${ }^{35}$

We focus on the model's implications for the expected rate of return on equity, $r^{e}$, and the risk-free rate, $r^{f}$, and hence for the equity premium. As it stands, the model is inadequate for explaining the volatility of asset prices, including stock prices. For example, the model unrealistically implies a constant price-dividend ratio and a constant risk-free rate. The most promising avenue for extending the model to fit these features-including the high volatility of stock returns-is to allow for shifting uncertainty parameters, notably the disaster probability, $p$. This possibility is explored in a recent paper by Xavier Gabaix; his results suggest that the extended model can explain volatility patterns without much affecting the implications for expected rates of return, including the equity premium. In a related vein, Ravi Bansal and Amir Yaron have pursued the consequences of shifting expected growth rates, $g^{*} \cdot{ }^{36}$

The calibrations of the model follow those in the forthcoming paper by Barro. We set the expected normal growth rate, $g$, at 0.025; the standard deviation of normal fluctuations, $\sigma$, at 0.02 ; and the reciprocal of the intertemporal elasticity of substitution, $\theta$, at $0.5 .{ }^{37}$ These choices of parameters either do not affect the equity premium ( $g$ and $\theta$ ) or have a negligible impact $(\sigma)$. The rate of time preference, $\rho$, also does not affect the equity premium. However, $\rho$ (along with $g, \sigma$, and $\theta$ ) affects levels of rates of return, including the risk-free rate, $r^{f}$ (see equations 6 and 7). Given the lack of useful outside information on $\rho$, we set $\rho *$ in equation 7 to generate $r^{f}=0.01$-roughly the long-run average across countries of real rates of

35. This issue is stressed by Weitzman (2007).

36. Gabaix (2008); Bansal and Yaron (2004).

37. For a discussion of the choice of $\theta$, including the problematic nature of estimates computed from macroeconomic time series, see Barro (forthcoming). 
return on bills from table $5{ }^{38}$ Then $\rho$ takes on the value needed to satisfy equation 5 .

The calibrations for the disaster probability, $p$, and the frequency distribution of disaster sizes, $b$, use our multicountry study of disaster events. We can then determine the value of $\gamma$ needed in equation 8 to replicate an unlevered equity premium of around 0.05 - the long-run average across countries implied by the data in table 5. Since we always have $r^{f}=0.01$, an unlevered equity premium of 0.05 corresponds to an expected rate of return on unlevered equity, $r^{e}$, of 0.06 .

Table 10 reports results of our simulation for crises gauged by $\mathrm{C}$, and table 11 for those gauged by GDP. For baseline cases, which encompass 95 observations of $\mathrm{C}$ crises and 152 observations of GDP crises, a coefficient of relative risk aversion, $\gamma$, of 3.5 gets the simulated results into the right ballpark for the observed equity premium: specifically, $r^{e}=0.059$ in the $\mathrm{C}$ case and 0.067 in the GDP case. The respective rates of time preference, $\rho$, are 0.045 and 0.052 , and the corresponding effective rates of time preference, $\rho^{*}$, are 0.029 and 0.037 .

The results are sensitive to the choice of $\gamma$. For example, the second lines of tables 10 and 11 show that if $\gamma=3.0$, the values for $r^{e}$ fall to 0.042 in the $\mathrm{C}$ case and 0.045 in the GDP case.

The results are not very different if the sample encompasses only the OECD countries, in which case the number of $C$ disasters falls from 95 to 57 , and the number of GDP disasters falls from 152 to 75 . The equity premium is still in the right ballpark with $\gamma=3.5$ (or slightly higher for $\mathrm{C}$ crises).

The results do not change greatly if we truncate the $b$ distribution to eliminate smaller crises. Tables 10 and 11 show the results when, instead of $b \geq 0.10$, we admit only $b \geq 0.15, b \geq 0.20, b \geq 0.30$, or $b \geq 0.40$. Even when $b \geq 0.40$, which leaves only eleven $C$ crises and fourteen GDP crises, $r^{e}$ is still at 0.047 in the case of $\mathrm{C}$ and 0.054 in the case of GDP. Thus, the larger crises are crucial for getting the equity premium into the right ballpark with a "reasonable" amount of risk aversion, such as $\gamma=3.5$.

This reasoning also applies when we examine nonwartime samples, a selection that eliminates the biggest crises from the sample. (We define "war" as applying only to active combatants.) For $\mathrm{C}$ crises, the consideration of a nonwartime sample-which retains sixty-six of the original

38. Real rates of return on treasury bills and similar assets are not risk-free and tend particularly to be lower than normal during crises that involve high inflation (see the section on "Asset Returns during Crises" below). Thus, $r^{f}$ may be lower than 0.01 . However, pegging to a lower value of $r^{f}$ would not affect our analysis of the equity premium. 


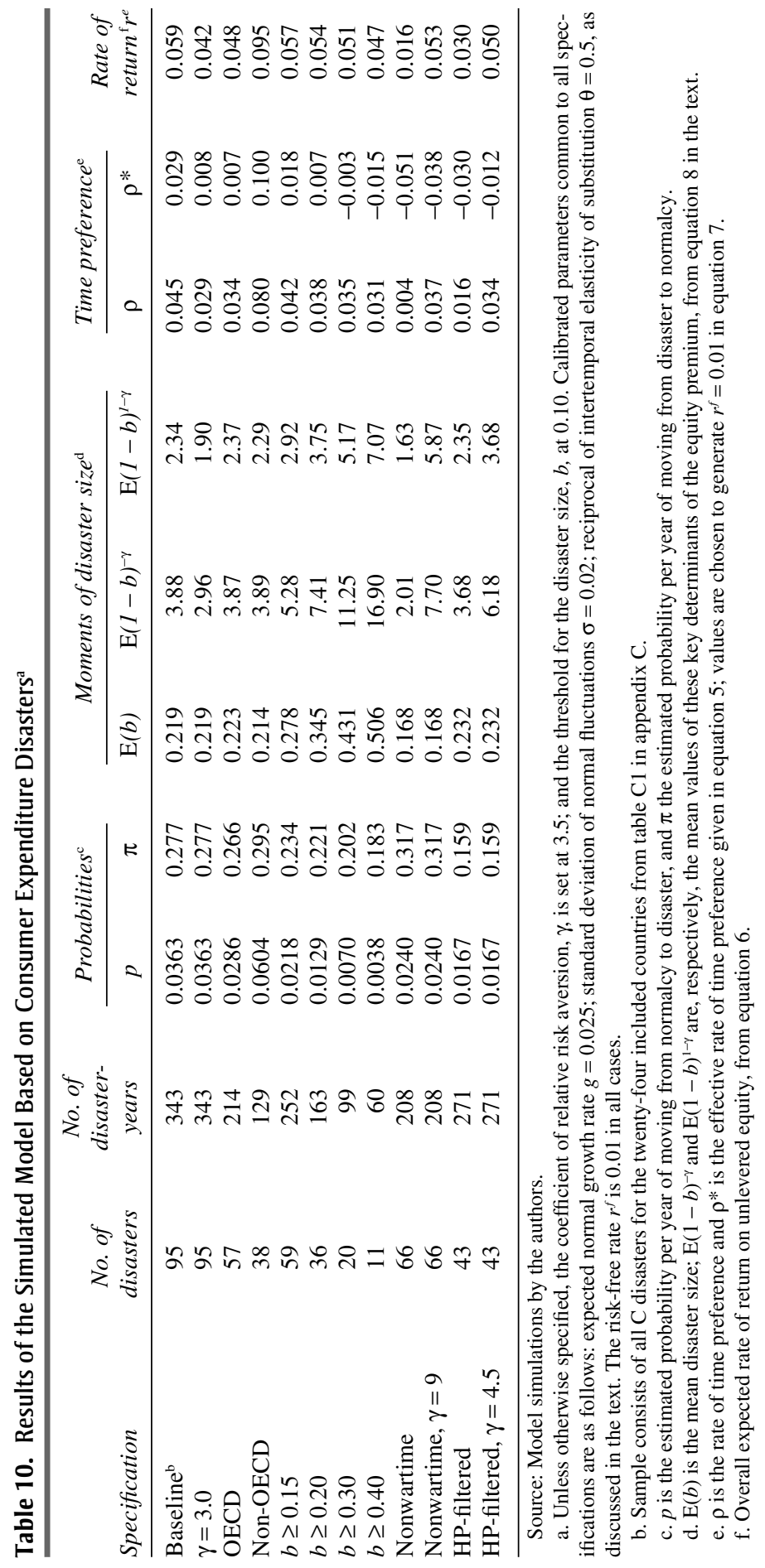




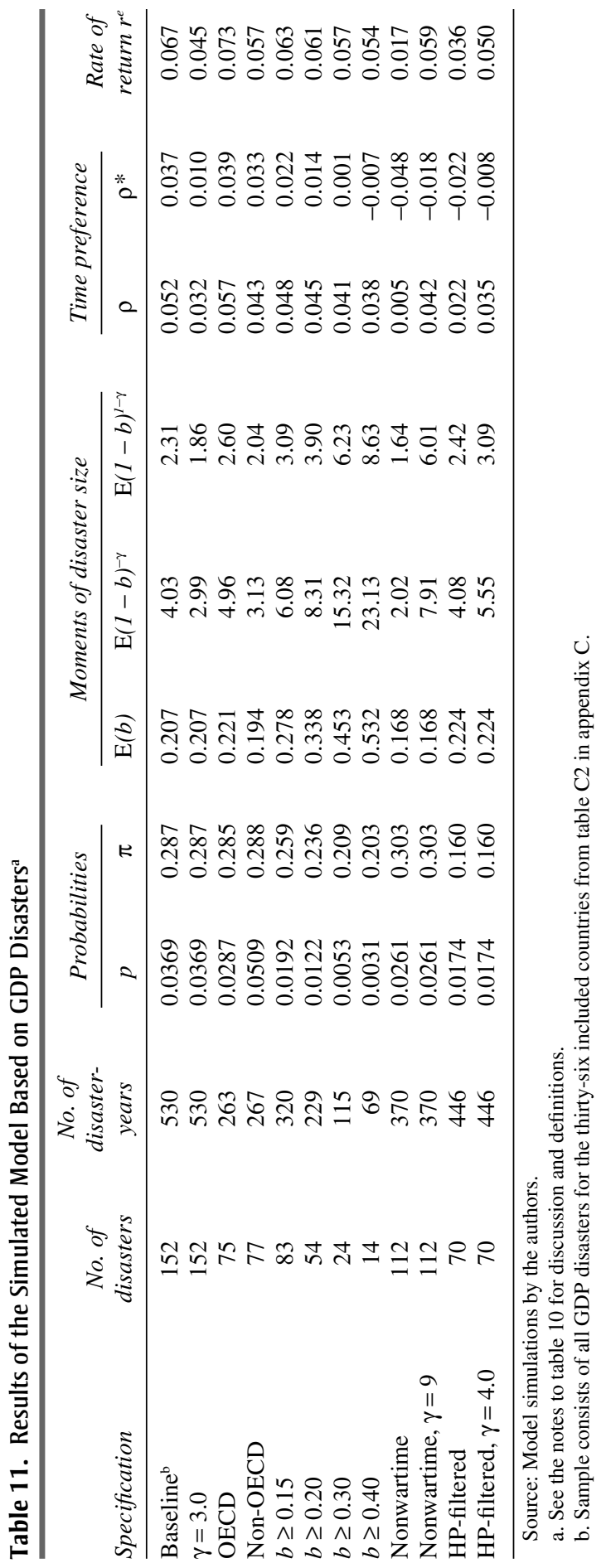


ninety-five disasters-yields $r^{e}=0.016$. For GDP crises, with 112 of the original 152 disasters retained, the result is $r^{e}=0.017$. Getting into the right ballpark here for the equity premium requires a much higher coefficient of relative risk aversion, $\gamma$. For example, tables 10 and 11 show that $\gamma$ $=9$ yields $r^{e}=0.053$ for $\mathrm{C}$ and 0.059 for GDP.

As discussed before, we redid the analysis using trend values of $\log (\mathrm{C})$ and $\log (\mathrm{GDP})$ calculated from HP filters. As already noted, this method captures in an informal way the idea that crises may have less than permanent effects on levels of $\mathrm{C}$ and GDP. Tables 10 and 11 show that the HP filtering reduces the number of $\mathrm{C}$ disasters from 95 to 43 and of GDP disasters from 152 to 70 . Correspondingly, the estimated disaster probabilities fall from 0.0363 to 0.0167 for $\mathrm{C}$ and from 0.0369 to 0.0174 for GDP. However, the size distributions of the crises are not so different from the baseline cases. For $\mathrm{C}$ crises the mean of $b$ is 0.232 , rather than 0.219 , and for GDP the mean is 0.224 , rather than 0.207 . Hence, the HP filtering decreases the number of disasters but slightly raises the average size, contingent on the occurrence of a disaster.

If we again use a coefficient of relative risk aversion, $\gamma$, of 3.5, the HP filtering lowers the computed $r^{e}$ to 0.030 for the $\mathrm{C}$ case and to 0.036 for the GDP case. However, $\gamma$ does not have to increase very much to restore a reasonable equity premium. For example, for $\mathrm{C}$ crises, $\gamma=4.5$ yields $r^{e}=$ 0.050 , whereas for GDP crises, $\gamma=4$ yields $r^{e}=0.050$.

In terms of broad patterns, the results based on $\mathrm{C}$ in table 10 deliver results for the equity premium that are similar to those based on GDP in table 11. On the one hand, this finding suggests a certain robustness, in that the results are not sensitive to measurement differences in these two main macroeconomic aggregates. On the other hand, it means that fitting the equity premium does not depend on our efforts in measuring consumer expenditure and thereby getting closer to measures of consumption.

Overall, the simulations in tables 10 and 11 show that the model delivers reasonable equity premia with "plausible" coefficients of relative risk aversion for a variety of specifications. The main lack of robustness applies to elimination of the biggest crises from the sample, for example, by removing the war-related crises.

\section{Asset Returns during Crises}

In our Lucas-tree model of asset returns, crises feature downward jumps in $\mathrm{C}$ and GDP at a point in time. More realistically, they fall gradually during crises of varying lengths, as suggested by figure 3 . In our empiri- 
cal analysis, we approximated the crisis declines in C and GDP by cumulative fractional amounts over peak-to-trough intervals, as shown in appendix tables $\mathrm{C} 1$ and $\mathrm{C} 2$ and figures 1 and 2 . Now we carry out a preliminary analysis that considers observed returns during crises on stocks and bills.

\section{Stock Returns during Crises}

In the theory, real stock prices jump down discretely at the start of a crisis. More realistically, stock prices would fall each time negative information hits the financial markets. Since we are conditioning on crises that cumulate to at least a 10 percent fall in C or GDP, the crises typically feature more than one adverse piece of news (or, rather, more negative than positive news). Thus, the stock-price declines tend also to be spread out during the crises. By analogy to our procedure for measuring decreases in $\mathrm{C}$ and GDP, we measure the crisis changes in stock prices by cumulative fractional amounts. Specifically, the real stockprice falls shown in appendix tables $\mathrm{C} 1$ and $\mathrm{C} 2$ are the total fractional declines from the end of the year before the peak to the end of the year before the trough. (Negative values indicate stock-price increases.) This procedure omits changes in stock prices during the trough year, when the financial markets would likely be influenced by information indicating that the crisis had ended.

Data on real stock prices are available for only a subset of the $\mathrm{C}$ and GDP crises: 54 of the $95 \mathrm{C}$ crises (appendix table C1) and 72 of the 152 GDP crises (table C2). The majority of these crises show declines in real stock prices: in forty-two of the fifty-four $\mathrm{C}$ events (78 percent) and fiftyfive of the seventy-two GDP events (76 percent). Figure 4 shows the size distribution of real stock-price declines during crises (where negative values correspond to stock-price rises). The left-hand panels show the full distributions, and the right-hand panels consider only the events with stock-price decreases. The left-hand panels have two outliers with very large price increases: Argentina in the late 1980s and Chile in the mid1970s. In these situations, periods of economic contraction were accompanied by major contemporaneous or prospective reforms that were viewed favorably by the stock markets. ${ }^{39}$ To admit the possibility of stock-price increases during crises into the model, we would have to expand the

39. An analogous situation is the $\mathrm{C}$ crisis in Venezuela in the late 1980s (see appendix table $\mathrm{C} 1$ ), which, however, is not included in the sample currently being considered. 
Figure 4. Distributions of Real Stock-Price Declines during Consumer Expenditure and GDP Disasters ${ }^{\mathrm{a}}$

All C disasters

No. of events

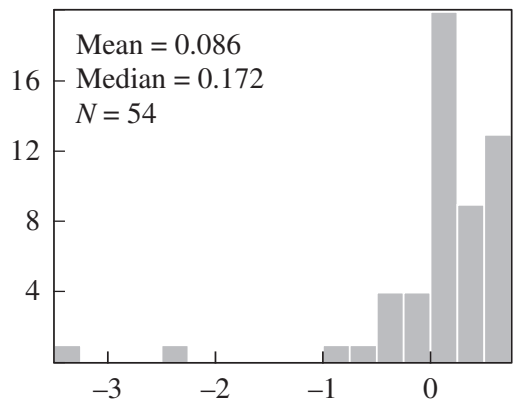

Cumulative fractional real decline ${ }^{b}$

No. of events

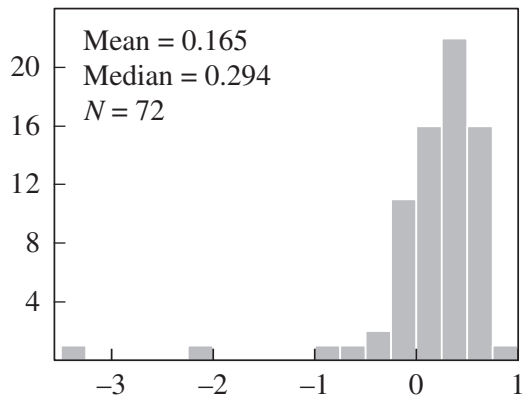

Cumulative fractional real decline ${ }^{b}$

\section{C disasters in which}

No. of events stock prices declined

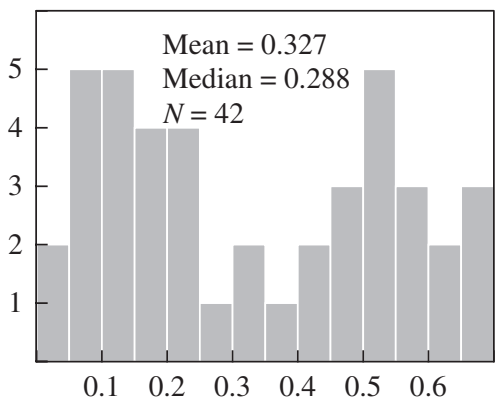

Cumulative fractional real decline

GDP disasters in which stock prices declined

No. of events

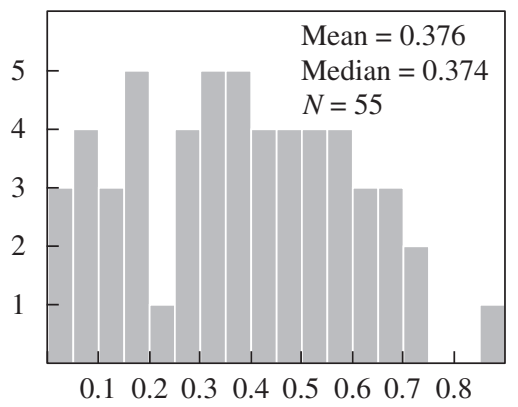

Cumulative fractional real decline

Source: See table 4.

a. The sample for consumer expenditure, $\mathrm{C}$, disasters is the 54 of 95 cases for included countries from table $\mathrm{C} 1$ with data on stock-price changes. The sample for GDP disasters is the 72 of 152 cases for included countries from table $\mathrm{C} 2$ with data on stock-price changes. We exclude cases in which missing data cause the period for stock-price changes to deviate from that for the declines in C or GDP.

b. Negative numbers indicate increases in real stock prices.

framework to allow for shocks to parameters, such as the expected growth rate, $g^{*}$, or the disaster probability, $p$.

The mean and median of fractional stock-price declines were 0.086 and 0.172 , respectively, for C crises and 0.165 and 0.294 for GDP crises. Conditioning on cases of stock-price decrease in the right-hand panels of figure 4 shows roughly uniform shapes for the frequency distributions in the 
range of sizes between zero and $0.7{ }^{40}$ In this range the mean and the median of stock-price declines were 0.327 and 0.288 , respectively, for $\mathrm{C}$ crises and 0.376 and 0.374 for GDP crises.

In tables 10 and 11 we simulated the underlying asset pricing model using the observed distributions of $\mathrm{C}$ and GDP crises. The underlying assumption was that the size of the fractional stock-price decline (for unlevered equity) during a crisis equaled the size of the fractional decline, $b$, in C or GDP. We can instead simulate the model by using the actual stock-price changes during crises, as shown in appendix tables $\mathrm{C} 1$ and $\mathrm{C} 2$ and in figure 4 . Since these stock returns refer to levered equity, these calculations apply to expected returns on levered equity.

The asset pricing condition in equation 4 involves the term $\mathrm{E}\left[R_{t} \cdot\right.$ $(1-b)^{-\gamma}$, where $R_{t}$ is the gross real stock return during crises, and $b$ is the fractional decline in C or GDP during crises. This expression is difficult to calculate accurately because stock-price changes are highly volatile, particularly during crises. ${ }^{41}$ In table 12 we compute this term in four alternative ways. First, we measure contractions by either C or GDP, and second, we use either the full distributions of stock-price changes (the left-hand panels of figure 4) or the truncated distributions that consider only stockprice declines (the right-hand panels). This last choice is more consistent with our model and may also lessen the effects from measurement error.

The calculations using the full distributions of stock-price changes do not accord well with observed long-term average returns on levered equity of around 0.081 (from table 5). If we use $\gamma=3.5$, as before, the simulations in table 12 deliver an overall mean rate of return on levered equity of 0.029 based on C crises and 0.031 based on GDP crises. The results fit better if we use the truncated distributions, which eliminate cases of stock-price increase during crises. The simulated mean rate of return on levered equity is then 0.075 based on $\mathrm{C}$ crises and 0.034 based on GDP crises. Given the wide range of results, we cannot, at this stage, reach firm conclusions from our attempts to simulate the model using observed stock-price changes during crises.

40. Recall that the samples are selected by considering C or GDP declines of 0.10 or more. We could instead select the sample by considering real stock-price declines of 0.10 or more. Our conjecture is that the size distributions would then look like power-law functions, as in figures 1 and 2 .

41. An additional difficulty is the imperfect matching of the timing of stock-price changes with the timing of the declines in C or GDP. In our data, stock-price changes are from the end of the year before the peak to the end of the year before the trough. The changes in C or GDP are from the peak year to the trough year, with C and GDP representing annual flows for each year. 
Table 12. Results of the Simulated Model Using Actual Stock-Price Changes during Crises ${ }^{\mathrm{a}}$

\begin{tabular}{|c|c|c|c|c|}
\hline & \multicolumn{2}{|c|}{ C crises } & \multicolumn{2}{|c|}{ GDP crises } \\
\hline & $\begin{array}{c}\text { All crises } \\
\text { with stock } \\
\quad \text { data }\end{array}$ & $\begin{array}{l}\text { Crises with } \\
\text { stock-price } \\
\text { decreases only }\end{array}$ & $\begin{array}{c}\text { All crises } \\
\text { with stock } \\
\quad \text { data }\end{array}$ & $\begin{array}{c}\text { Crises with } \\
\text { stock-price } \\
\text { decreases only }\end{array}$ \\
\hline No. of observations & 54 & 42 & 72 & 55 \\
\hline $\begin{array}{l}\text { Coefficient of relative } \\
\text { risk aversion } \gamma\end{array}$ & 3.5 & 3.5 & 3.5 & 3.5 \\
\hline $\begin{array}{l}\text { Effective time-preference } \\
\text { rate } \rho^{*}\end{array}$ & 0.029 & 0.029 & 0.037 & 0.037 \\
\hline Normal growth rate $g$ & 0.025 & 0.025 & 0.025 & 0.025 \\
\hline$(1+g)^{-\gamma}$ & 0.917 & 0.917 & 0.917 & 0.917 \\
\hline Disaster probability $p$ & 0.0363 & 0.0363 & 0.0369 & 0.0369 \\
\hline \multicolumn{5}{|l|}{ Stock returns ${ }^{\mathrm{b}}$} \\
\hline $\begin{array}{l}\text { Overall mean } \mathrm{E}\left(R_{t}-1\right) \\
\quad(\text { from table } 5)\end{array}$ & 0.0814 & 0.0814 & 0.0814 & 0.0814 \\
\hline $\begin{array}{l}\text { Mean of crisis sample } \\
\quad \mathrm{E}\left(R_{t}-1\right)\end{array}$ & -0.0864 & -0.3272 & -0.1655 & -0.3759 \\
\hline $\begin{array}{l}\text { Mean of crisis sample } \\
\mathrm{E}\left[R_{t} \cdot(1-b)^{-\gamma}\right]\end{array}$ & 3.446 & 1.964 & 3.545 & 3.235 \\
\hline \multicolumn{5}{|l|}{ Model simulation } \\
\hline $\begin{array}{l}\text { Implied noncrisis }^{\mathrm{c}} \\
\mathrm{E}\left(R_{t}-1\right)\end{array}$ & 0.035 & 0.090 & 0.038 & 0.050 \\
\hline $\begin{array}{l}\text { Implied overall mean }{ }^{\mathrm{d}} \\
\mathrm{E}\left(R_{t}-1\right)\end{array}$ & 0.029 & 0.075 & 0.031 & 0.034 \\
\hline
\end{tabular}

Source: Authors' calculations.

a. The parameters $\gamma, \rho^{*}, g$, and $p$ come from tables 10 and 11. Stock-price changes during crises are reported in tables $\mathrm{C} 1$ and $\mathrm{C} 2$. The four crisis samples used are $\mathrm{C}$ crises with data on stock-price changes $(N=54), \mathrm{C}$ crises with stock-price decreases $(N=42)$, GDP crises with data on stock-price changes $(N=72)$, and GDP crises with stock-price decreases $(N=55)$.

b. "Mean of crisis sample $\mathrm{E}\left(R_{t}-1\right)$ " is the mean for each crisis sample of the fractional change in real stock prices. "Mean of crisis sample $\mathrm{E}\left[R_{t} \cdot(1-\mathrm{b})^{-\gamma}\right]$ " is the mean for each crisis sample of the interaction between $\left(1+\right.$ fractional change in real stock prices) and $(1-b)^{-\gamma}$, where $b$ is the fractional decline in C or GDP.

c. Based on the following approximate formula, derived from equations 2 through 4 in the text (neglecting the effects from normal fluctuations, $\sigma$ ):

$$
1+\rho^{*} \approx(1+g)^{-\gamma} \cdot\left\{p \cdot \mathrm{E}\left[R_{t} \cdot(1-b)^{-\gamma}\right]_{\mid c r i s i s}+(1-p) \cdot\left(\mathrm{E} R_{t}\right)_{\mid \text {noncrisis }}\right\} .
$$

d. Based on the formula $\mathrm{E}\left(R_{t}\right)=p \cdot\left(\mathrm{E} R_{t}\right)_{\mid \text {crisis }}+(1-p) \cdot\left(\mathrm{E} R_{t}\right)_{\mid \text {noncrisis }}$.

\section{Bill Returns during Crises}

In the Lucas-tree model, the risk-free rate is the same in normal times as in a crisis, which lasts an instant of time. The same pattern would apply to the expected real rate of return on short-term bills - the type of claim considered in table 5-if we introduce a constant probability of default or, for nominal claims, a time-invariant process for inflation. 
Table 13. Bill Returns and Inflation Rates during Crises ${ }^{\mathrm{a}}$

\begin{tabular}{|c|c|c|c|c|c|c|}
\hline \multirow[b]{2}{*}{ Item } & \multicolumn{3}{|c|}{$C$ crises } & \multicolumn{3}{|c|}{ GDP crises } \\
\hline & $N$ & Mean & Median & $N$ & Mean & Median \\
\hline Real rate of return on bills & 58 & -0.051 & -0.023 & 73 & -0.052 & -0.021 \\
\hline Inflation rate & 87 & 1.13 & 0.066 & 123 & 0.961 & 0.069 \\
\hline
\end{tabular}

Source: Authors' calculations.

a. The results apply to the crisis samples used in the main analysis: $95 \mathrm{C}$ crises from table $\mathrm{C} 1$ and 152 GDP crises from table C2. Data for real rates of return on bills and inflation rates are for the subsamples that also have data on bill returns or inflation rates, as indicated in tables $\mathrm{C} 1$ and $\mathrm{C} 2$. The cells show means and medians of real rates of return on bills and inflation rates for these subsamples.

Observed returns on short-term bills deviate from these predictions. Table 13 shows means and medians for real bill returns during the $\mathrm{C}$ and GDP crises in appendix tables $\mathrm{C} 1$ and $\mathrm{C} 2$. (The bill returns for each crisis are mean values from the peak year to one year before the trough year.) These results apply to the main samples (95 C crises and 152 GDP crises) when data are also available on bill returns ( 58 for $\mathrm{C}$ crises and 73 for GDP crises). The average real bill return during crises was between -2 percent and -5 percent a year, depending on whether a $\mathrm{C}$ or a GDP sample is used and on whether the mean or the median is considered. Hence, the average crisis return was below the long-term average of around 1 percent shown in table 5 .

There are two main issues to consider. The first is whether a substantially negative number, such as -2 percent to -5 percent a year, is a good measure of expected real bill returns during crises. A major question here concerns inflation. The second is whether our analysis of the equity premium would be much affected if the expected real return on bills during crises were substantially negative. Since the second issue is more fundamental, and we think the answer is no, we consider that question first.

One possible reason for a low equilibrium expected real bill return during crises, suggested by figure 3 , is that crisis states last for more than an instant, and the mean growth rate of $\mathrm{C}$ in these states is negative. (A supporting reason, not shown in figure 3 , is that volatility tends to be unusually high in crisis states.) In these cases the risk-free rate and the expected real bill return would be unusually low in crises. However, the key issue for the equity premium is not the low level of the real bill return during crises (caused by a low expected growth rate or some other factor) but, rather, whether the incidence of a crisis imposes substantial real capital losses on bills. Recall that bills correspond, empirically, to claims with maturity of three months or less. Although the crisis-induced changes in the real value of these claims are hard to measure accurately, substantial 
real capital losses can arise only if there are jumps in the price level or literal defaults on bills. Absent these effects, the pricing of bills in normal times (and, hence, the equity premium) would not be much influenced by the prospect of low equilibrium real bill returns during crises. ${ }^{42}$ In contrast, for long-term bonds, changes in real capital values at the onsets of crises may be substantial and would have to be compared with those on stocks. Thus it would be useful to analyze the crisis experiences of the ten-year government bonds included in table 5. However, the measurement of crisis-induced changes in real bond values will be challenging.

A different point is that the computed averages of real bill returns during crises may understate expected real returns because of influences from inflation. Crises do feature higher than usual inflation rates: table 13 shows that the median inflation rates were 6.6 percent for $C$ crises and 6.9 percent for GDP crises, compared with 4.2 percent for long samples for all countries taken together ${ }^{43}$ Hence, one possible explanation for the low average real bill return during crises is that the greater incidence of high inflation corresponds to high unanticipated inflation and, thereby, to a shortfall of realized real returns on nominally denominated bills from expected returns. A shortcoming of this argument is that it requires inflation to be systematically underestimated during crises (which are presumably recognized contemporaneously).

A second possibility is that the reported nominal yields at times of high inflation systematically understate the true nominal returns and, therefore, lead to underestimates of the real returns. The reason is the understatement of the implications of compounding for calculating true nominal returns. ${ }^{44}$

42. An analogous result holds for paper currency. The expected real return on currency would be low during a crisis if the expected inflation rate were high. However, absent jumps in the price level or literal defaults, currency held in normal times would still provide good protection against crisis-induced stock-market crashes.

43. The inflation rate for each crisis in tables $\mathrm{C} 1$ and $\mathrm{C} 2$ is the mean value from the peak year to one year before the trough year.

44. As an example, Peru's crisis in 1987-92 featured very high inflation. In 1989 the price level increased by a factor of 29. The International Monetary Fund's International Financial Statistics (IFS) reports, on a monthly basis, nominal deposit yields for 1989 averaging 1,100 percent a year. The IFS staff tell us that an annual rate of 1,100 percent means that the nominal value of funds held as deposits would rise over a year by a factor of 12 . This nominal return, in conjunction with the inflation experience, produces a real rate of return for Peru in 1989 of -0.58 per year. Suppose, alternatively, that a nominal yield of 1,100 percent means that returns are compounded monthly at a rate of 92 percent $(=1,100 / 12)$ per month. In this case the nominal value would rise over a year by a factor of 2,500 , implying an astronomically positive real rate of return. The point is that when the inflation rate is high, compounding errors of this type have large implications for calculated real rates of returnand we think that these errors are regularly in the direction of understating true returns. 
We think that this issue is quantitatively important, and we are attempting to improve our calculations in this regard.

\section{Plans for Further Research}

We plan in future research to expand the twenty-four-country sample for C and the thirty-six-country sample for GDP. Promising candidates are Malaysia and Singapore, both of which have gaps in the data around World War II. Also promising are Russia back to the pre-World War I tsarist period, and Turkey back to the times of the Ottoman Empire, for which we currently have data since 1923 . We are also considering Ireland, particularly whether we can isolate macroeconomic data for the territory of the Republic of Ireland from U.K. statistics for the period preceding Irish independence in 1922. We plan also to reexamine the pre-1929 U.S. data, focusing on the Civil War years.

We will try to go further in measuring the division of personal consumer expenditure between durables versus nondurables and services. Appendix table $\mathrm{C} 3$ shows the data that we have been able to compile thus far for crisis periods. We may also attempt to add data on government consumption. A key issue here is the separation of military outlays from other forms of government consumption expenditure.

We plan to construct time series for C and GDP per capita at the levels of regions that include multiple countries: the OECD, Western Europe, Latin America, Asia, the "world," and so on. These regional aggregates can be relevant when countries are integrated through financial and other markets. There are tricky aspects of this exercise involving changes in country borders, and we are working on this issue. Once we have these superaggregate variables, we will examine $\mathrm{C}$ and GDP crises at regional levels.

In joint work with Rustam Ibragimov, we will use the method of Gabaix and Ibragimov to estimate the distribution of disaster sizes, $b$, within a power-law context. ${ }^{45}$ Preliminary analysis shows good results when treating the transformed variable $1 /(1-b)$ as subject to a power-law density function with exponent $\alpha$. With these results we can compute the key expectations that enter into the theoretical model, such as $\mathrm{E}(1-b)^{-\gamma}$, as functions of $\gamma$ and $\alpha$. Preliminary results suggest that the estimated $\alpha$, around 5, is consistent with a finite value of $\mathrm{E}(1-b)^{-\gamma}$, when $\gamma$ is around 3.5. With these results, we can redo the simulation of the model using the fitted density function for $b$, rather than the observed histogram. 
We are working with Emi Nakamura and Jón Steinsson on a formal statistical model of the evolution of consumer expenditure and GDP. We will use the full time series on C and GDP to estimate the probability of disaster (possibly time-varying), the evolution of economic contractions during disaster states, the probability of return to normalcy, and the longrun effects of disasters on levels and growth rates of $\mathrm{C}$ and GDP. We will also allow for trend breaks in growth rates, as well as for some differences in uncertainty parameters across countries and over time.

We are working with Emmanuel Farhi and Xavier Gabaix on a different approach to measuring time-varying disaster probabilities. Our plan is to use U.S. data since the early 1980 s on prices of stock-index options to gauge changing market perceptions of the likelihood of substantial adverse shocks. In addition to considering the equity premium, we will apply this analysis to the bond-bill premium, which we found to be about 1 percent a year.

ACKNOWLEDGMENTS The National Science Foundation has supported this research. We thank for suggestions Olivier Blanchard, John Campbell, George Constantinides, Emmanuel Farhi, Xavier Gabaix, Claudia Goldin, Rustam Ibragimov, Dale Jorgenson, Emi Nakamura, and Jón Steinsson. We appreciate help with the financial data from Bryan Taylor of Global Financial Data. On the construction of the database on GDP and personal consumer expenditure, we are grateful for comments and contributions from many people worldwide. A nonexhaustive list includes Roberto Cortés (Argentina); Felix Butschek, Anton Kausel, Felix Rauscher, Marcus Schleibecker, and Rita Schwarz (Austria); Frans Buelens, Erik Buyst, Jean-Jacques Heirwegh, Yves de Lombaerde, Kim Oosterlinck, Peter Scholliers, Yves Segers, Eric Vanhaute, and Guy Vanthemsche (Belgium); Claudio Haddad (Brazil); José Diaz and Eric Haindl (Chile); Adolfo Meisel, Carlos Posada, and Miguel Urrutia (Colombia); Jakob Madsen (Denmark); Riitta Hjerppe and Visa Heinonen (Finland); Claude Diebolt, Thomas Piketty, Gilles Postel-Vinay, and Pierre Villa (France); Carsten Burhop, Davide Cantoni, Nicola Fuchs-Schündeln, Albrecht Ritschl, Mark Spoerer, Beatrice Weder, and Guntram Wolff (Germany); Violetta Hionidou, George Kostelenos, and George Manolas (Greece); Guðmundur Jónsson (Iceland); Mausumi Das, Ramesh Kolli, Bharat Ramaswami, Bhanoji Rao, Partha Sen, S. L. Shetty, Rohini Somanathan, and Nittala Subrahmanyasastry (India); Ann Booth, Pierre van der Eng, and Kees van der Meer (Indonesia); Stefano Fenoaltea (Italy); Yana Kandaiya, 
H. R. H. Raja Nazrin, and Wan Rahim Wan Ahmad (Malaysia); Aurora Gómez, Stephen Haber, Sandra Kuntz, Jaime de la Llata, Graciela Márquez, and John Womack (Mexico); Marjan Balkestein, Ferry Lapré, Herman de Jong, Hein Klemann, Jan-Pieter Smits, and Jan Luiten van Zanden (Netherlands); Brian Easton, Anthony Endres, Les Oxley, Andrew Petty, Jakob Preston, Keith Rankin, Grant Scobie, and John Singleton (New Zealand); Ola Grytten and Karin Snesrud (Norway); José Robles (Peru); Ricardo Jose and Richard Hooley (Philippines); Luzia Estevens, Pedro Lains, and José Tavares (Portugal); Paul Gregory (Russia); Ichiro Sugimoto (Singapore); Olu Akimboade and Jon Inggs (South Africa); Myung-Soo Cha, Nak-Nyeon Kim, Mitsuhiko Kimura, Jong-Wha Lee, and Dwight Perkins (South Korea); Leandro Prados (Spain); Rodney Edvinsson (Sweden); Felix Andrist, Philippe Bacchetta, Stefan Gerlach, and Stefanie Schnyder (Switzerland); Şevket Pamuk (Turkey); and Jorge Alvarez and Inés Morales (Uruguay). Many other researchers provided invaluable contributions through their published work. All errors remain our own. 


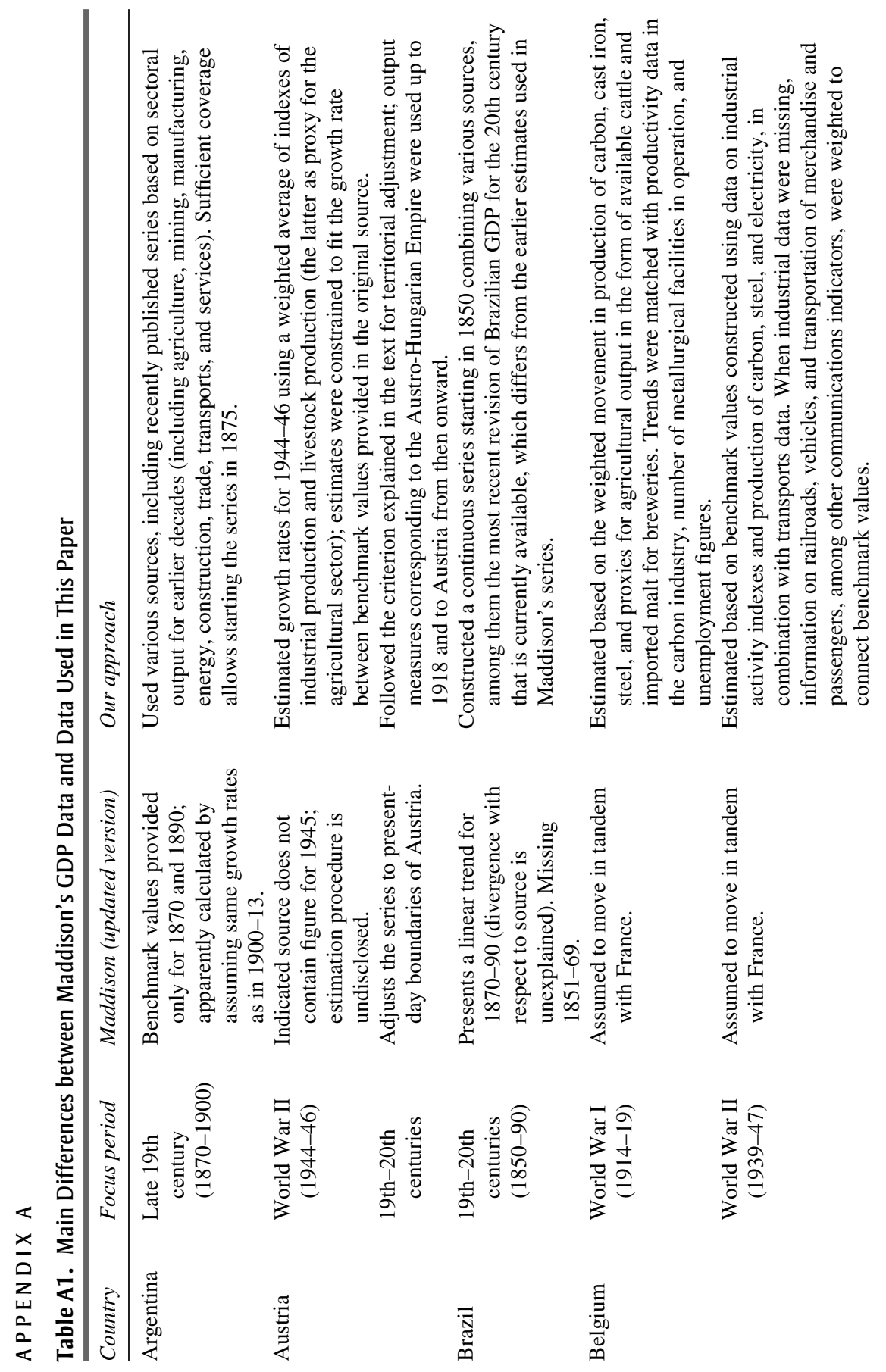




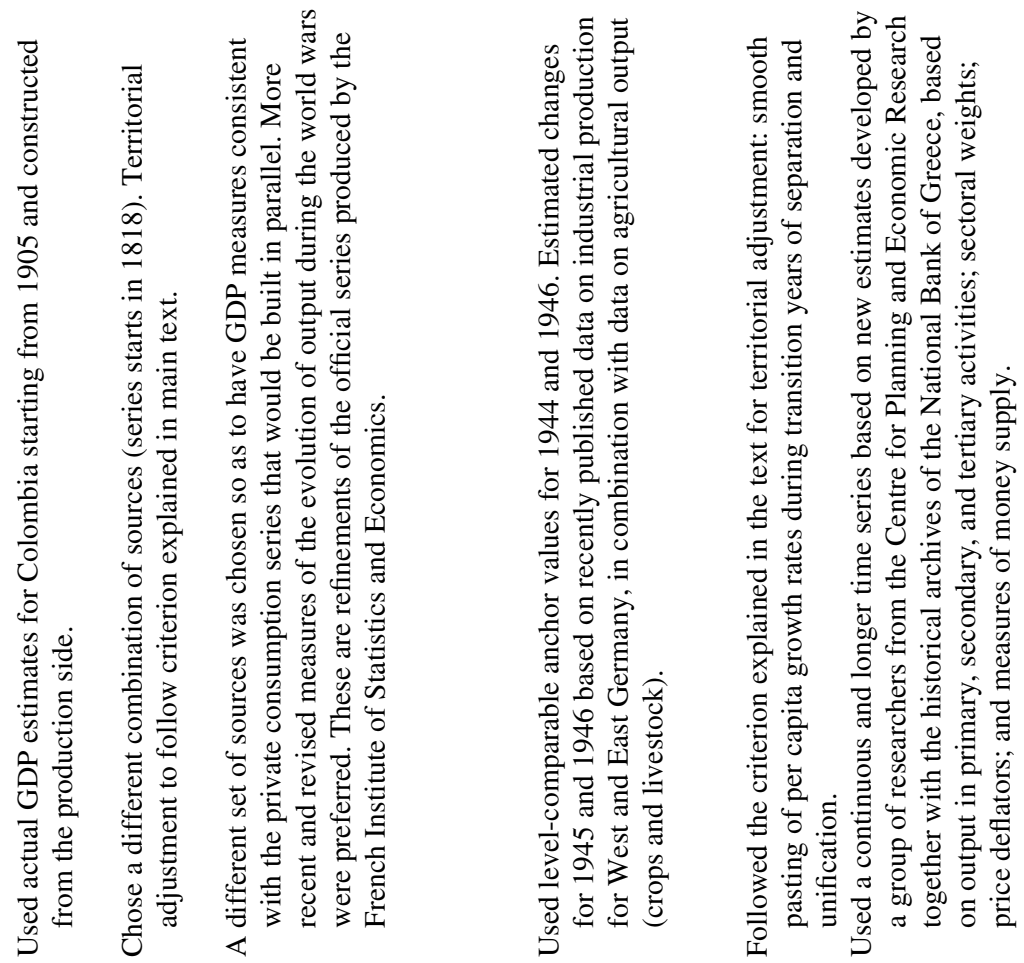

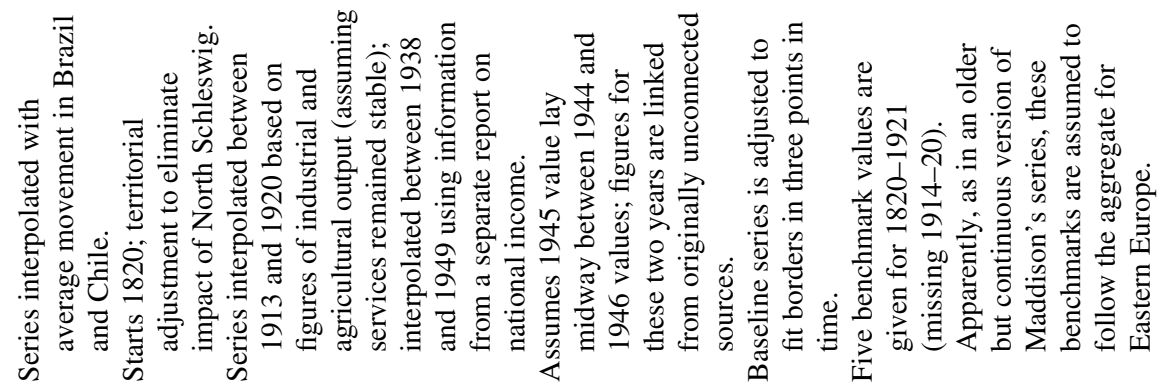

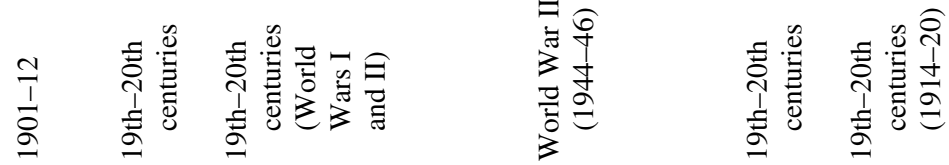

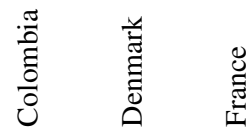

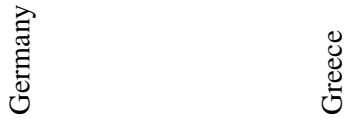




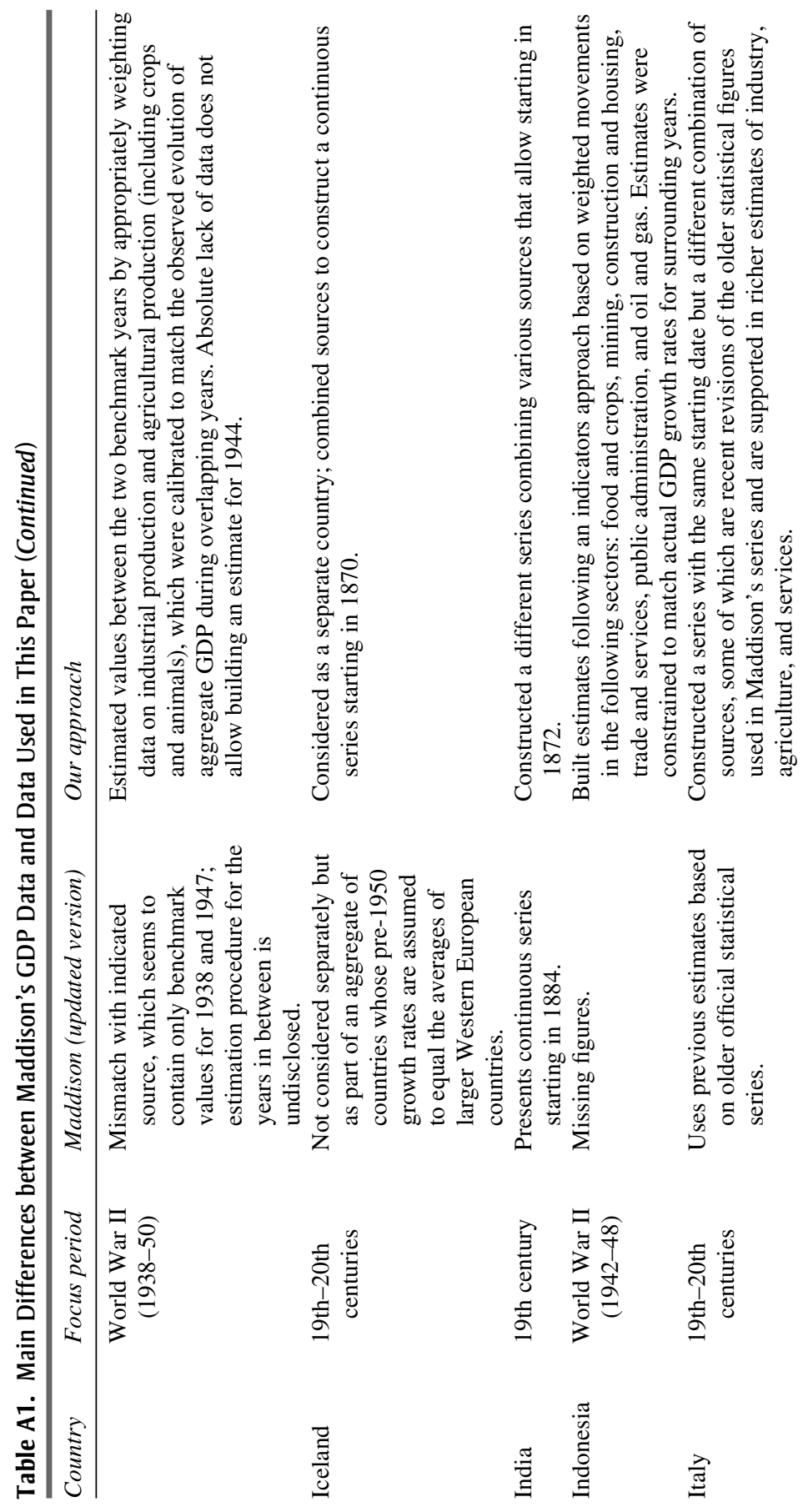




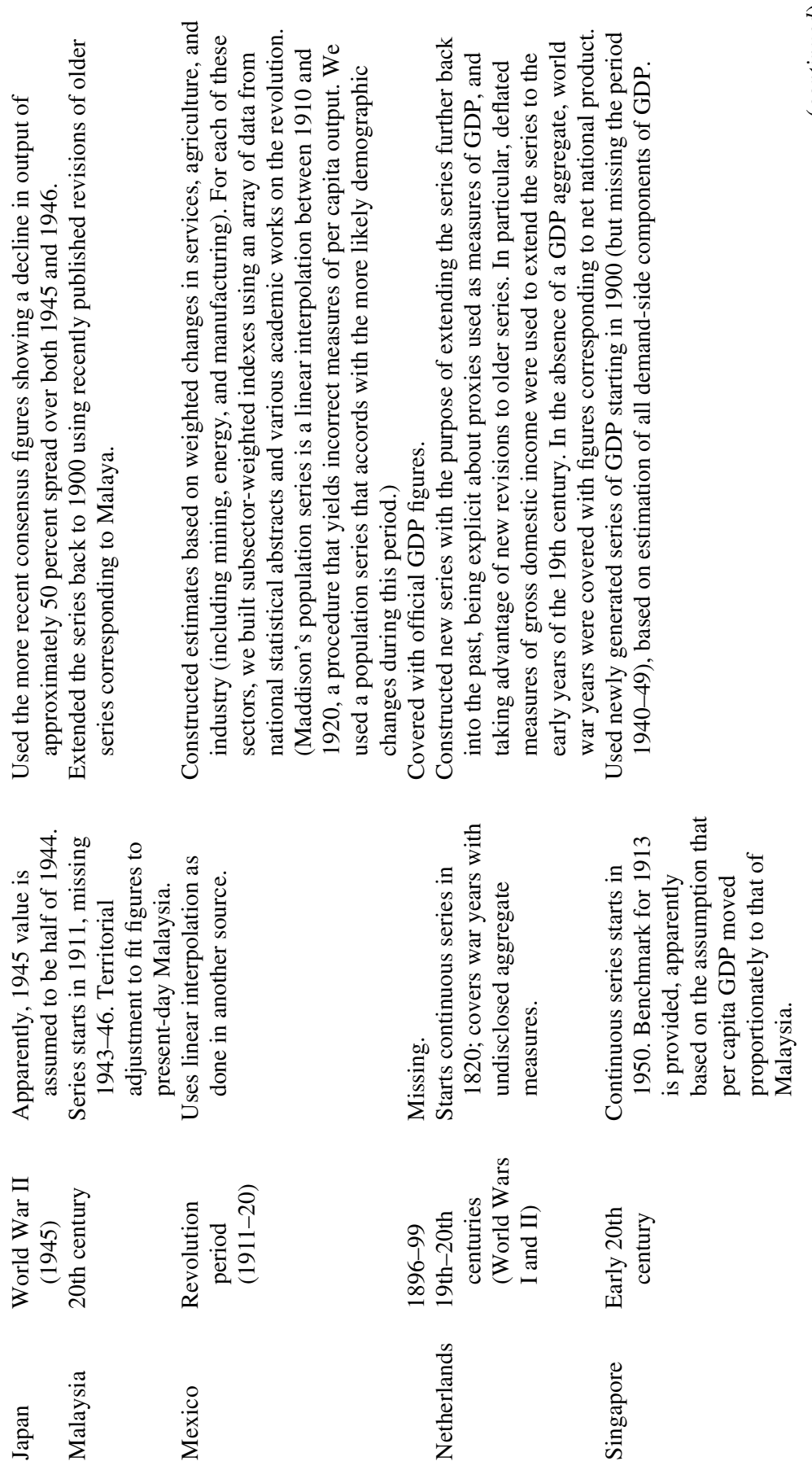




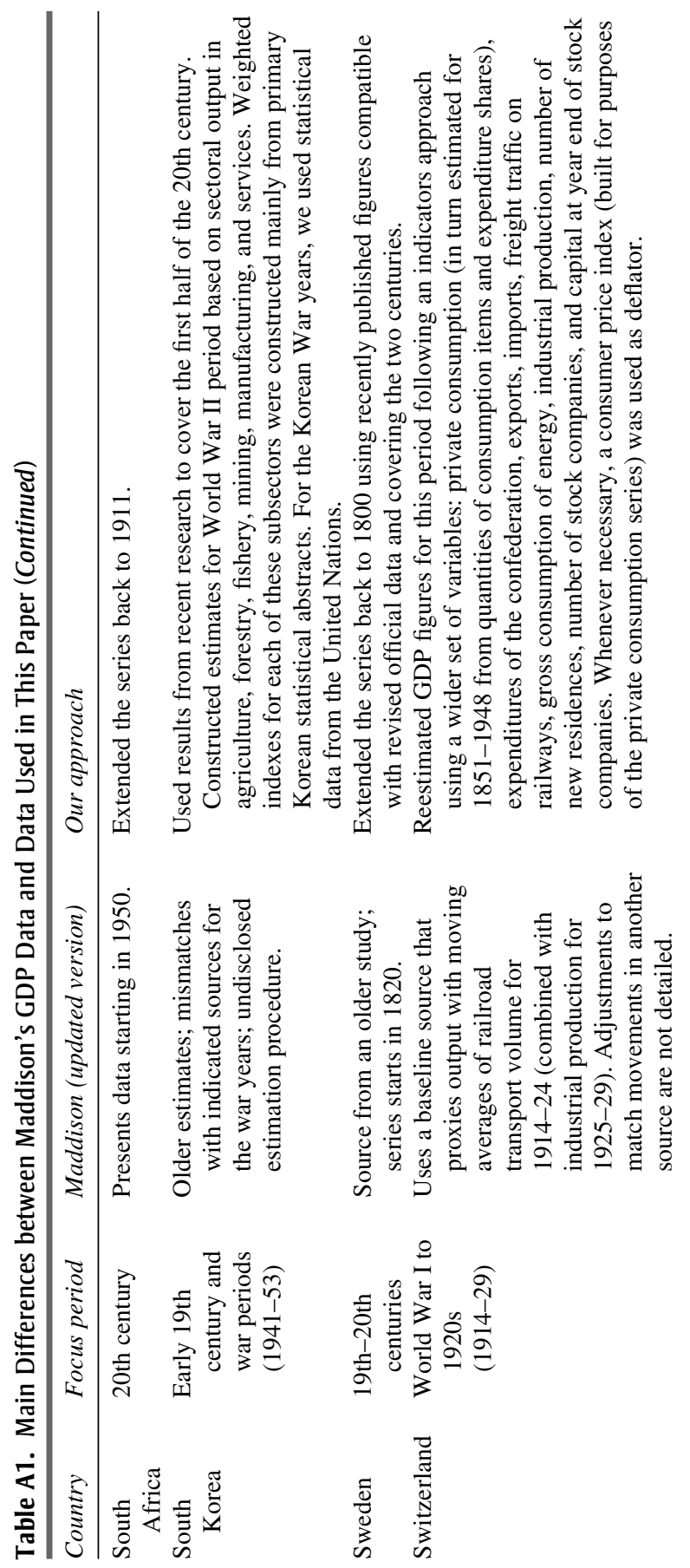




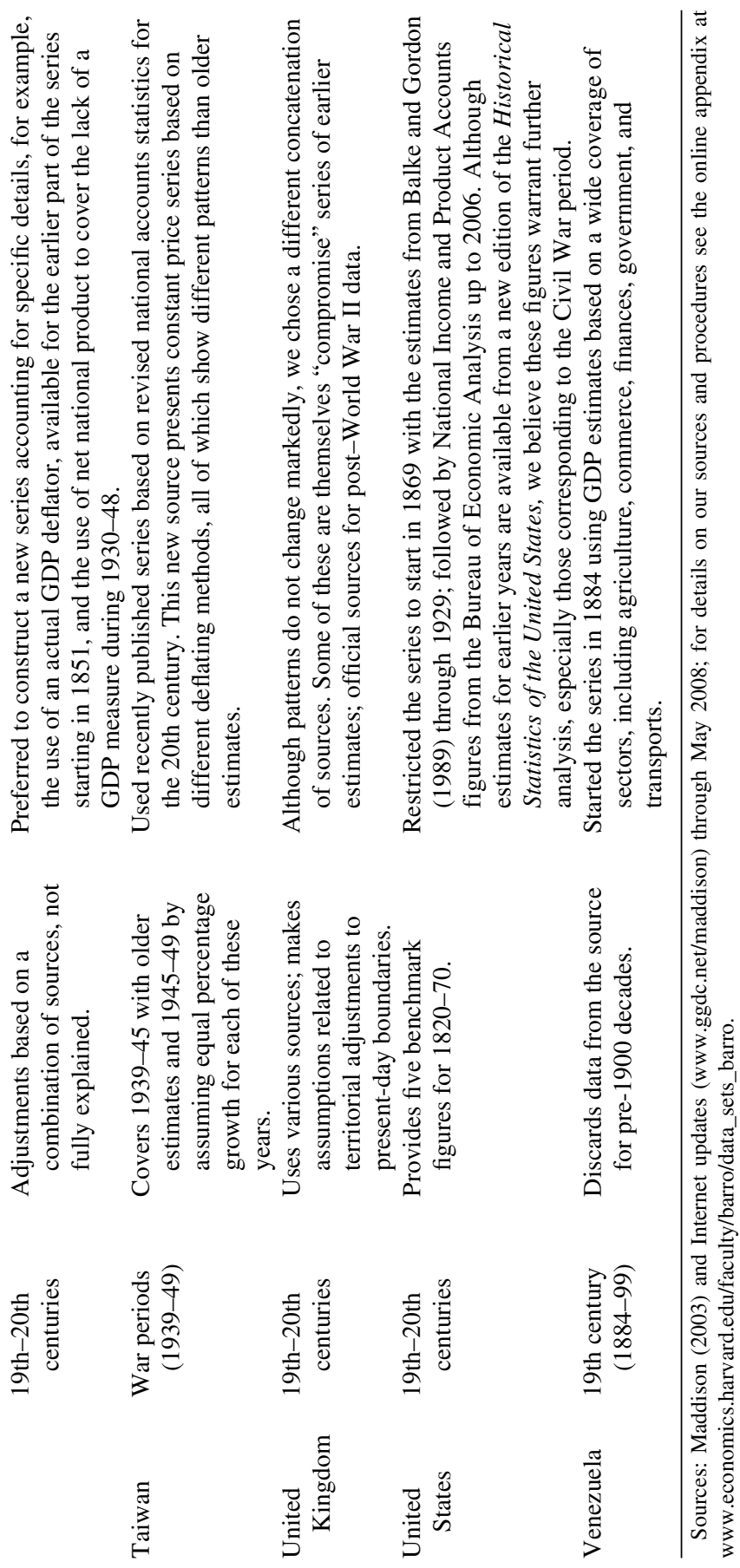


APPENDIX B

\section{Real Consumption and GDP per Capita by Country}

Figure B1. Real Personal Consumer Expenditure and GDP per Capita in OECD Countries ${ }^{\mathrm{a}}$
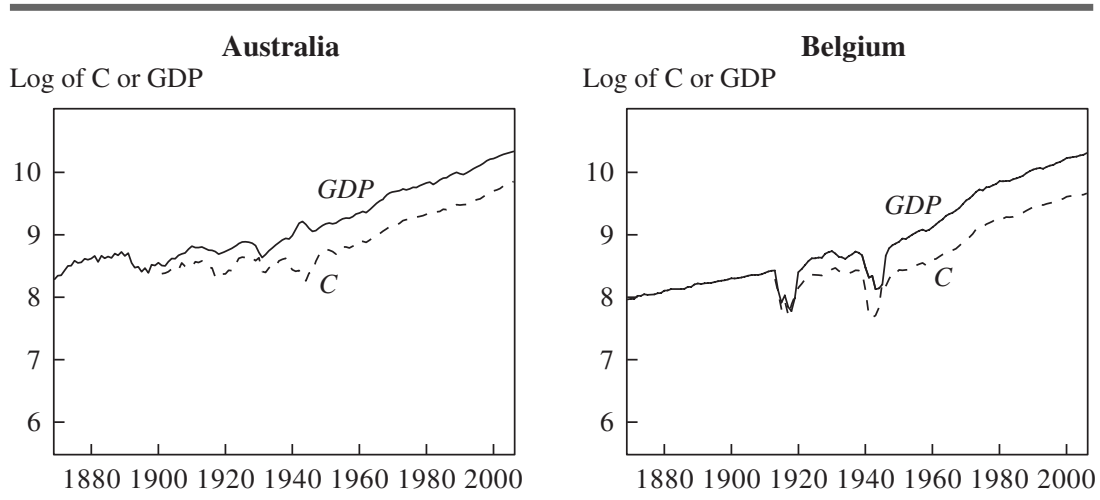

Canada

Log of C or GDP

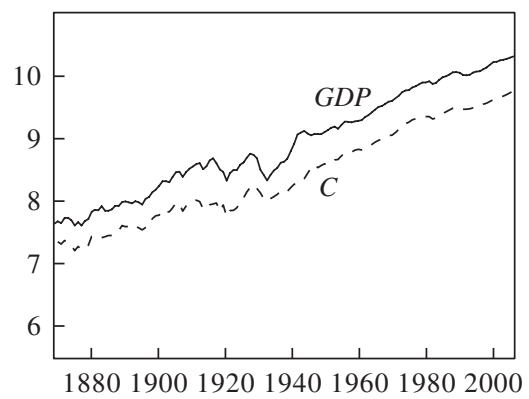

Log of C or GDP

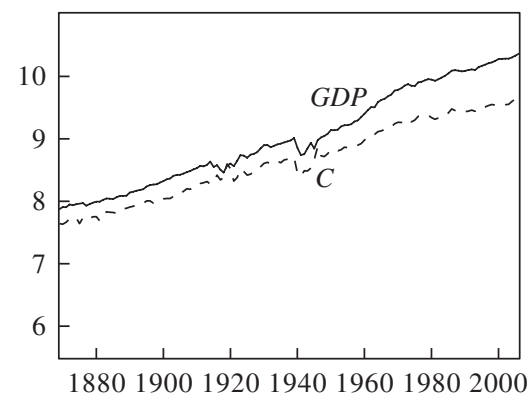

Finland

Log of C or GDP

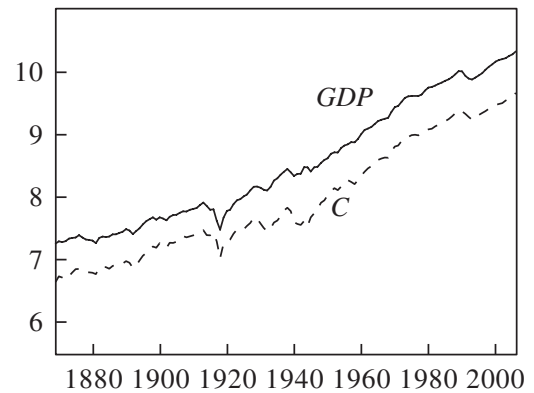

$\log$ of $\mathrm{C}$ or GDP

\section{France}

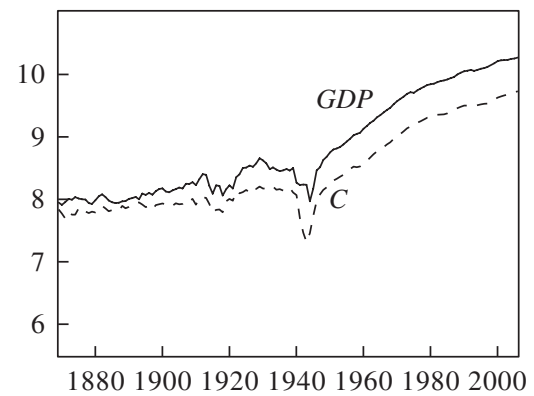


Figure B1. Real Personal Consumer Expenditure and GDP per Capita in OECD Countries ${ }^{\mathrm{a}}$ (Continued)

\section{Germany}

Log of C or GDP

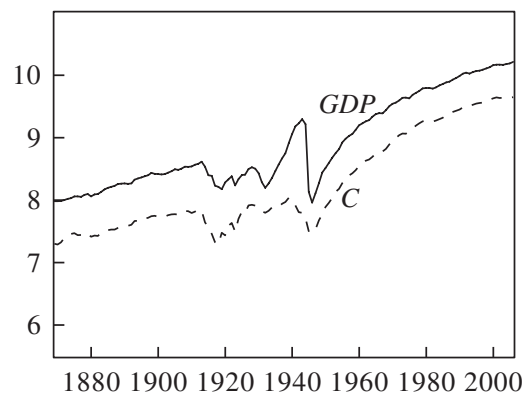

Japan

Log of C or GDP

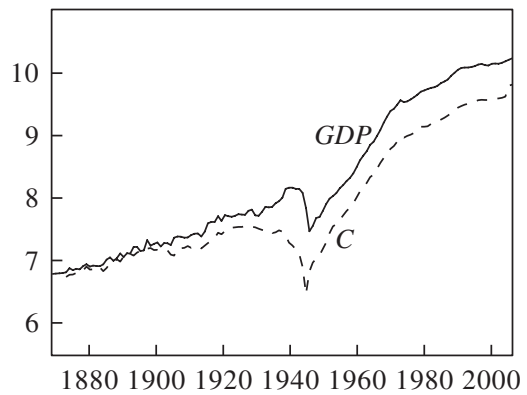

Norway

Log of C or GDP

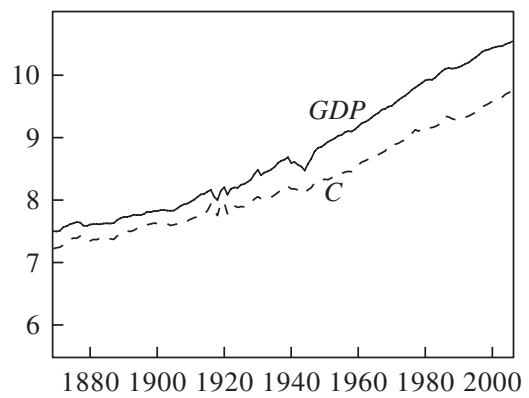

Italy

$\log$ of $\mathrm{C}$ or GDP

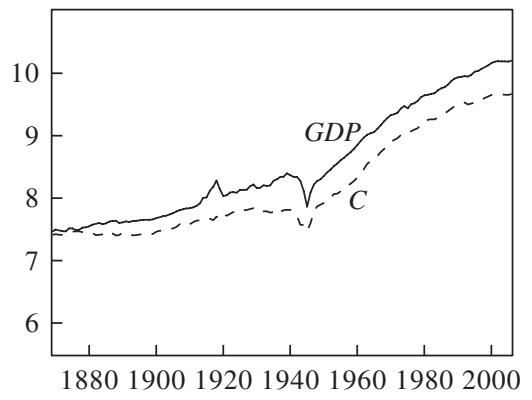

Netherlands

$\log$ of $\mathrm{C}$ or GDP

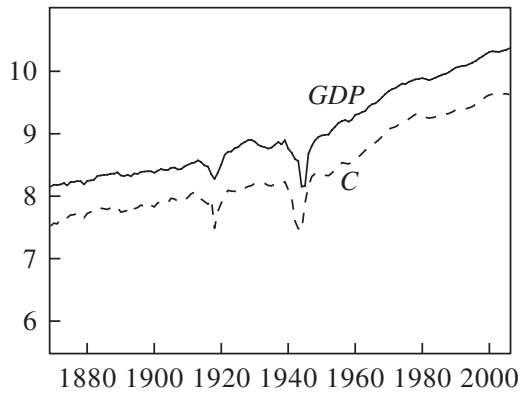

Portugal

$\log$ of $\mathrm{C}$ or GDP

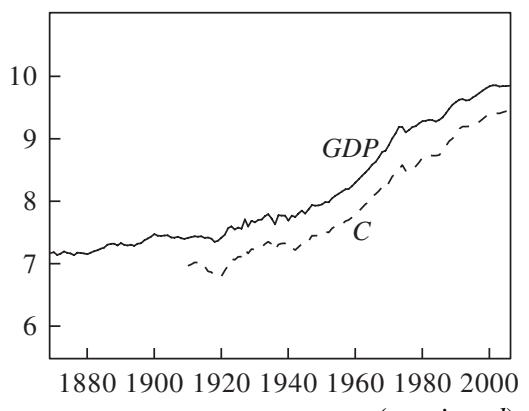


Figure B1. Real Personal Consumer Expenditure and GDP per Capita in OECD Countries ${ }^{\mathrm{a}}$ (Continued)

Spain

$\log$ of $C$ or GDP

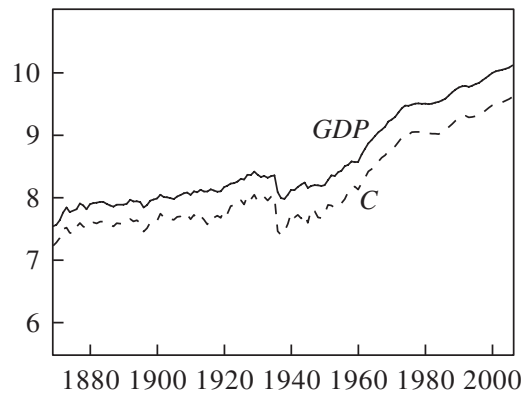

Switzerland

$\log$ of $\mathrm{C}$ or GDP

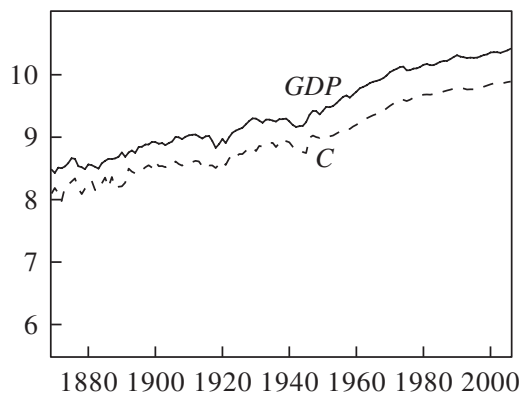

Sweden

Log of C or GDP

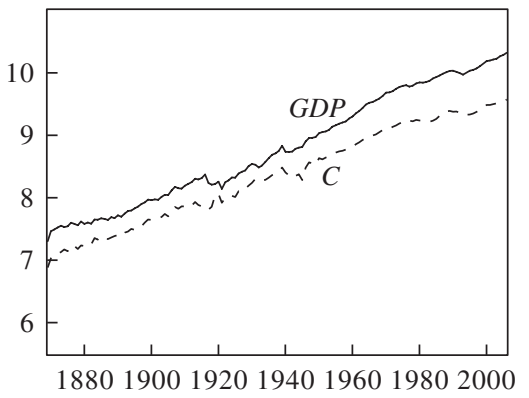

United Kingdom

Log of C or GDP

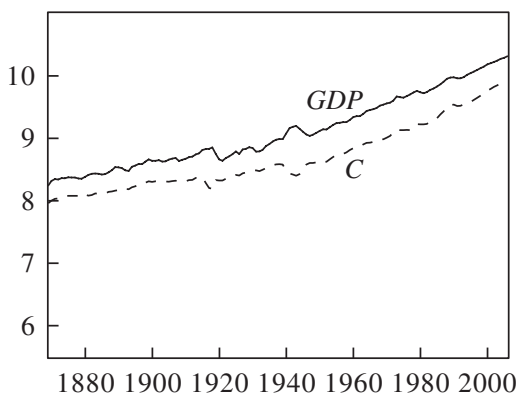

\section{United States}

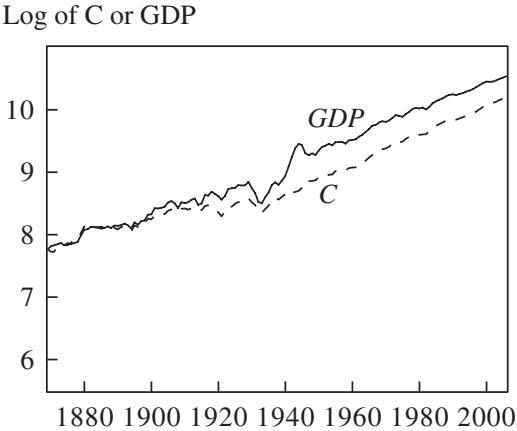

Source: Authors' construction; for details on sources see www.economics.harvard.edu/faculty/barro/ data_sets_barro.

a. Log scale ranges from 5.5 to 11.0 (\$245 to $\$ 59,900$, respectively, in 2000 U.S. dollars). Series start in 1869 or later depending on data availability. 
Figure B2. Real Personal Consumer Expenditure and GDP per Capita in Non-OECD Countries ${ }^{\mathrm{a}}$
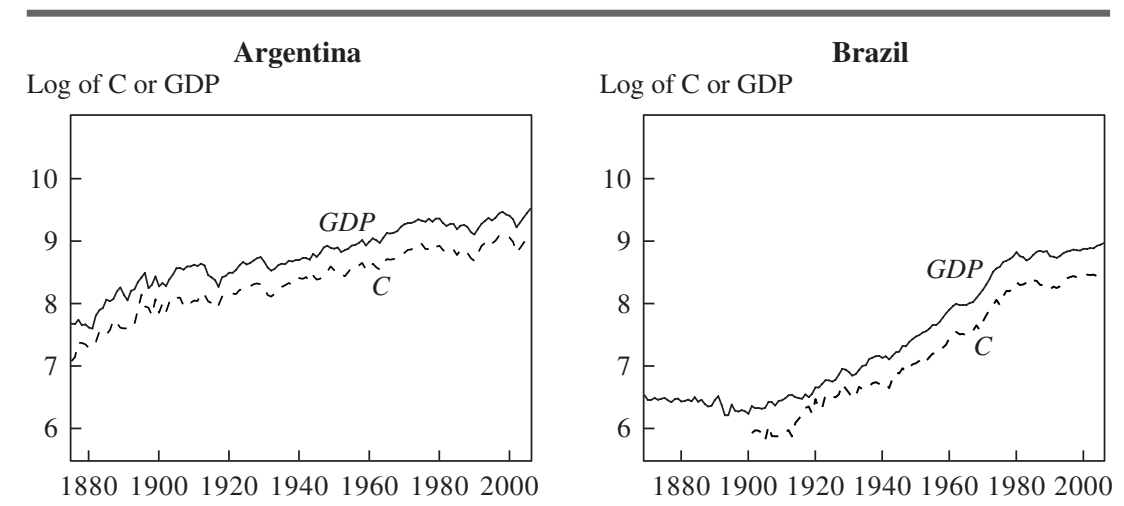

Chile
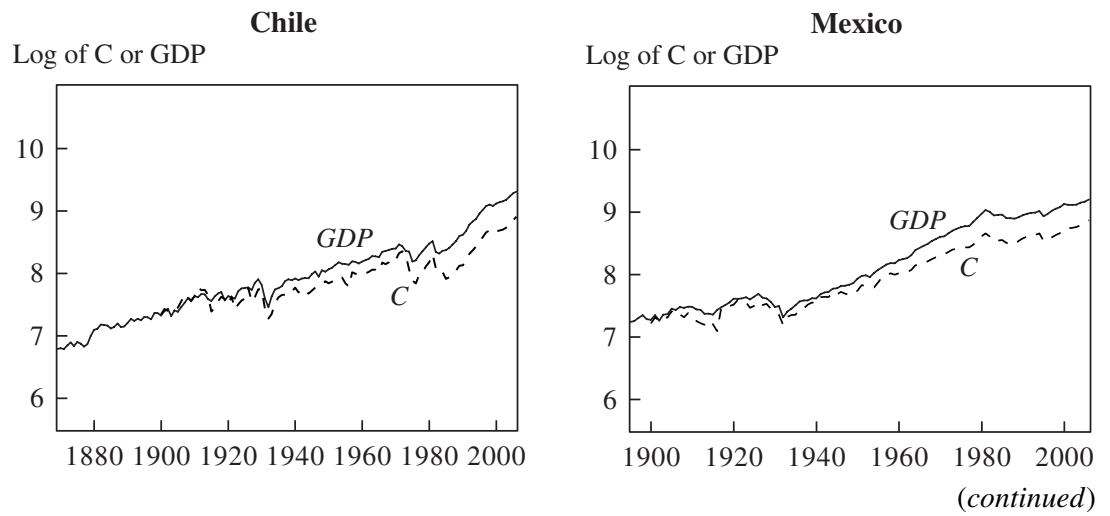
Figure B2. Real Personal Consumer Expenditure and GDP per Capita in Non-OECD Countries (Continued)
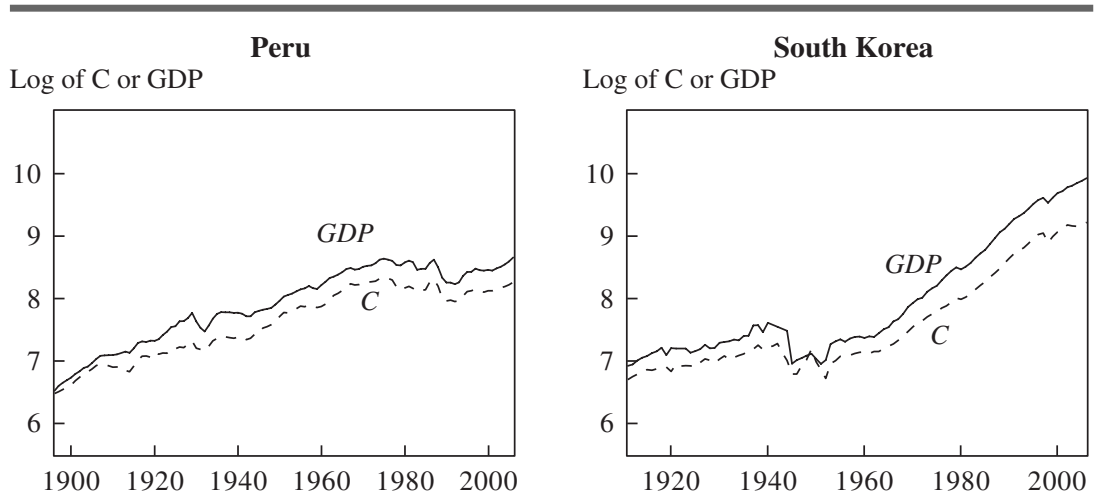

\section{Taiwan}

Log of C or GDP

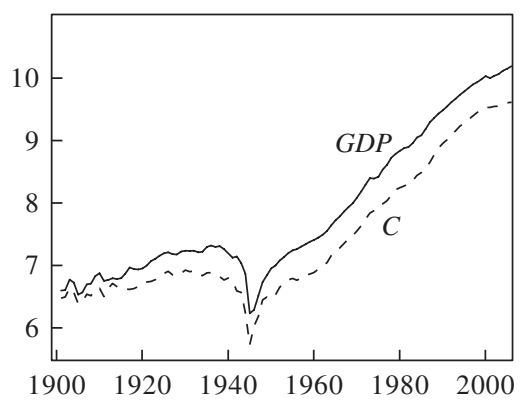

Source: Authors' construction; for details on sources see www.economics.harvard.edu/faculty/barro/ data_sets_barro.

a. Log scale ranges from 5.5 to 11.0 (\$245 to $\$ 59,900$, respectively, in 2000 U.S. dollars). Series start in 1869 or later depending on data availability. 
APPENDIX C

Characteristics of Consumption and GDP Disasters

Table C1. Consumption Disasters

\begin{tabular}{|c|c|c|c|c|c|c|}
\hline \multirow[b]{2}{*}{ Country } & \multicolumn{2}{|c|}{ Disaster period } & \multirow{2}{*}{$\begin{array}{c}\text { Decline in } \\
\text { consumer } \\
\text { expenditure } \\
\text { per capita }^{\mathrm{b}}\end{array}$} & \multirow{2}{*}{$\begin{array}{l}\text { Stock- } \\
\text { price } \\
\text { decline }^{\mathrm{c}}\end{array}$} & \multirow{2}{*}{$\begin{array}{l}\text { Rate of } \\
\text { return } \\
\text { on bills }{ }^{\mathrm{d}}\end{array}$} & \multirow{2}{*}{$\begin{array}{l}\text { Inflation } \\
\text { rate }^{\mathrm{d}}\end{array}$} \\
\hline & Trough $^{\mathrm{a}}$ & Peak & & & & \\
\hline \multicolumn{7}{|c|}{ OECD countries } \\
\hline \multirow[t]{3}{*}{ Australia } & 1918 & 1913 & 0.238 & 0.144 & -0.008 & 0.036 \\
\hline & 1932 & 1927 & 0.234 & 0.069 & 0.086 & -0.032 \\
\hline & 1944 & 1938 & 0.301 & 0.225 & -0.024 & 0.041 \\
\hline \multirow[t]{3}{*}{ Austria $^{e}$} & 1918 & 1913 & 0.451 & - & 0.034 & 0.019 \\
\hline & 1933 & 1929 & 0.217 & 0.533 & 0.071 & -0.004 \\
\hline & 1947 & 1938 & 0.438 & - & - & - \\
\hline \multirow[t]{2}{*}{ Belgium } & 1917 & 1913 & 0.445 & - & -0.160 & 0.353 \\
\hline & 1942 & 1937 & 0.530 & - & -0.024 & 0.034 \\
\hline \multirow[t]{5}{*}{ Canada } & 1876 & 1873 & 0.152 & - & - & -0.023 \\
\hline & 1908 & 1906 & 0.113 & - & 0.014 & -0.046 \\
\hline & 1915 & 1912 & 0.130 & - & $0.022^{\mathrm{f}}$ & 0.034 \\
\hline & 1921 & 1918 & 0.196 & 0.210 & - & 0.104 \\
\hline & 1933 & 1929 & 0.230 & 0.650 & - & -0.054 \\
\hline \multirow[t]{3}{*}{ Denmark } & 1921 & 1919 & 0.241 & 0.502 & -0.113 & 0.201 \\
\hline & 1941 & 1939 & 0.261 & 0.336 & -0.120 & 0.193 \\
\hline & 1948 & 1946 & 0.144 & 0.040 & 0.005 & 0.025 \\
\hline \multirow[t]{5}{*}{ Finland } & 1892 & 1890 & 0.102 & - & - & - \\
\hline & 1918 & 1913 & 0.360 & - & $-0.194^{\mathrm{g}}$ & $0.389^{\mathrm{g}}$ \\
\hline & 1932 & 1928 & 0.199 & 0.207 & 0.115 & -0.041 \\
\hline & 1944 & 1938 & 0.254 & 0.168 & -0.067 & 0.122 \\
\hline & 1993 & 1989 & 0.140 & 0.620 & 0.092 & 0.045 \\
\hline \multirow[t]{3}{*}{ France } & 1871 & 1864 & 0.158 & 0.212 & 0.027 & 0.007 \\
\hline & 1915 & 1912 & 0.215 & 0.171 & 0.031 & 0.006 \\
\hline & 1943 & 1938 & 0.580 & - & -0.121 & 0.162 \\
\hline \multirow[t]{4}{*}{ Germany } & 1918 & 1912 & 0.425 & 0.539 & -0.101 & 0.186 \\
\hline & 1923 & 1922 & 0.127 & 0.654 & -0.970 & 34.5 \\
\hline & 1932 & 1928 & 0.121 & 0.562 & 0.109 & -0.035 \\
\hline & 1945 & 1939 & 0.412 & -0.366 & 0.000 & 0.020 \\
\hline \multirow[t]{2}{*}{ Greece $^{e}$} & 1944 & 1938 & 0.636 & $0.442^{\mathrm{h}}$ & -0.442 & 4.65 \\
\hline & 1946 & 1945 & 0.113 & - & - & - \\
\hline \multirow[t]{4}{*}{ Iceland $^{\mathrm{e}}$} & 1952 & 1947 & 0.250 & - & - & 0.202 \\
\hline & 1969 & 1967 & 0.118 & - & - & 0.108 \\
\hline & 1975 & 1974 & 0.107 & - & - & 0.515 \\
\hline & 1993 & 1987 & 0.176 & - & $0.060^{\mathrm{i}}$ & 0.144 \\
\hline Italy & 1945 & 1939 & 0.286 & 0.429 & -0.236 & 1.02 \\
\hline Japan & 1945 & 1937 & 0.639 & 0.457 & -0.066 & 0.101 \\
\hline \multirow[t]{3}{*}{ Netherlands } & 1893 & 1889 & 0.098 & - & -0.013 & 0.038 \\
\hline & 1918 & 1912 & 0.440 & - & -0.013 & 0.060 \\
\hline & 1944 & 1939 & 0.545 & -0.506 & -0.050 & 0.069 \\
\hline New Zealand ${ }^{e}$ & 1944 & 1939 & 0.224 & 0.089 & -0.009 & 0.031 \\
\hline
\end{tabular}


Table C1. Consumption Disasters (Continued)

\begin{tabular}{|c|c|c|c|c|c|c|}
\hline \multirow[b]{2}{*}{ Country } & \multicolumn{2}{|c|}{ Disaster period } & \multirow{2}{*}{$\begin{array}{l}\text { Decline in } \\
\text { consumer } \\
\text { expenditure } \\
\text { per capita }^{\mathrm{b}}\end{array}$} & \multirow{2}{*}{$\begin{array}{c}\text { Stock- } \\
\text { price } \\
\text { decline }^{\mathrm{c}}\end{array}$} & \multirow{2}{*}{$\begin{array}{l}\text { Rate of } \\
\text { return } \\
\text { on bills }\end{array}$} & \multirow{2}{*}{$\begin{array}{l}\text { Inflation } \\
\text { rate }^{\mathrm{d}}\end{array}$} \\
\hline & Trough $^{\mathrm{a}}$ & Peak & & & & \\
\hline \multirow[t]{3}{*}{ Norway } & 1918 & 1916 & 0.169 & -0.035 & -0.212 & 0.326 \\
\hline & 1921 & 1919 & 0.161 & 0.536 & -0.032 & 0.094 \\
\hline & 1944 & 1939 & 0.100 & -0.222 & -0.062 & 0.090 \\
\hline \multirow[t]{4}{*}{ Portugal } & 1919 & 1913 & 0.215 & - & - & - \\
\hline & 1936 & 1934 & 0.121 & -0.434 & 0.044 & 0.010 \\
\hline & 1942 & 1939 & 0.104 & 0.084 & -0.058 & 0.110 \\
\hline & 1976 & 1974 & 0.098 & - & -0.136 & 0.242 \\
\hline \multirow[t]{6}{*}{ Spain } & 1896 & 1892 & 0.182 & -0.088 & 0.079 & -0.024 \\
\hline & 1915 & 1913 & 0.128 & 0.065 & 0.021 & 0.026 \\
\hline & 1930 & 1929 & 0.101 & 0.090 & 0.027 & 0.028 \\
\hline & 1937 & 1935 & 0.461 & $0.238^{\mathrm{j}}$ & -0.051 & 0.058 \\
\hline & 1945 & 1940 & 0.145 & -0.079 & -0.021 & 0.107 \\
\hline & 1949 & 1946 & 0.131 & 0.014 & -0.029 & 0.075 \\
\hline \multirow[t]{3}{*}{ Sweden } & 1917 & 1913 & 0.115 & 0.095 & -0.014 & 0.074 \\
\hline & 1921 & 1920 & 0.132 & 0.251 & 0.052 & 0.019 \\
\hline & 1945 & 1939 & 0.182 & 0.173 & -0.030 & 0.059 \\
\hline \multirow[t]{7}{*}{ Switzerland } & 1872 & 1870 & 0.190 & - & - & - \\
\hline & 1878 & 1876 & 0.225 & - & - & - \\
\hline & 1883 & 1881 & 0.142 & - & - & -0.018 \\
\hline & 1886 & 1885 & 0.141 & - & - & -0.059 \\
\hline & 1888 & 1887 & 0.157 & - & - & 0.010 \\
\hline & 1918 & 1912 & 0.108 & 0.475 & -0.031 & 0.088 \\
\hline & 1945 & 1939 & 0.173 & 0.382 & -0.052 & 0.074 \\
\hline \multirow[t]{2}{*}{ United Kingdom } & 1918 & 1915 & 0.167 & 0.490 & -0.117 & 0.188 \\
\hline & 1943 & 1938 & 0.169 & 0.123 & -0.032 & 0.047 \\
\hline \multirow[t]{2}{*}{ United States } & 1921 & 1917 & 0.164 & 0.584 & -0.071 & 0.139 \\
\hline & 1933 & 1929 & 0.208 & 0.631 & 0.093 & -0.064 \\
\hline \multicolumn{7}{|c|}{ Non-OECD countries } \\
\hline \multirow[t]{11}{*}{ Argentina } & 1891 & 1887 & 0.123 & - & - & 0.080 \\
\hline & 1898 & 1895 & 0.283 & - & - & 0.030 \\
\hline & 1900 & 1899 & 0.195 & - & - & -0.096 \\
\hline & 1902 & 1901 & 0.127 & - & - & 0.059 \\
\hline & 1907 & 1906 & 0.123 & - & - & 0.025 \\
\hline & 1917 & 1912 & 0.172 & - & - & 0.047 \\
\hline & 1932 & 1928 & 0.189 & - & - & -0.028 \\
\hline & 1959 & 1958 & 0.101 & - & - & 0.507 \\
\hline & 1982 & 1980 & 0.104 & 0.575 & 0.516 & 1.09 \\
\hline & 1990 & 1987 & 0.160 & -3.264 & -0.249 & 18.3 \\
\hline & 2002 & 1998 & 0.249 & 0.401 & 0.090 & -0.009 \\
\hline \multirow[t]{6}{*}{ Brazil } & 1905 & 1902 & 0.148 & - & - & -0.029 \\
\hline & 1909 & 1906 & 0.157 & - & - & 0.023 \\
\hline & 1919 & 1918 & 0.109 & - & - & 0.123 \\
\hline & 1921 & 1920 & 0.147 & - & - & 0.099 \\
\hline & 1931 & 1928 & 0.201 & - & - & -0.037 \\
\hline & 1990 & 1984 & 0.163 & -0.271 & - & 6.42 \\
\hline
\end{tabular}


Table C1. Consumption Disasters (Continued)

\begin{tabular}{|c|c|c|c|c|c|c|}
\hline \multirow[b]{2}{*}{ Country } & \multicolumn{2}{|c|}{ Disaster period } & \multirow{2}{*}{$\begin{array}{c}\text { Decline in } \\
\text { consumer } \\
\text { expenditure } \\
\text { per capita }^{\mathrm{b}}\end{array}$} & \multirow{2}{*}{$\begin{array}{c}\text { Stock- } \\
\text { price } \\
\text { decline }^{\mathrm{c}}\end{array}$} & \multirow{2}{*}{$\begin{array}{l}\text { Rate of } \\
\text { return } \\
\text { on bills }\end{array}$} & \multirow{2}{*}{$\begin{array}{c}\text { Inflation } \\
\text { rate }^{\mathrm{d}}\end{array}$} \\
\hline & Trough $^{\mathrm{a}}$ & Peak & & & & \\
\hline \multirow[t]{6}{*}{ Chile } & 1915 & 1911 & 0.322 & 0.125 & 0.021 & 0.069 \\
\hline & 1922 & 1918 & 0.181 & 0.154 & 0.011 & 0.085 \\
\hline & 1932 & 1929 & 0.374 & 0.538 & 0.063 & 0.007 \\
\hline & 1956 & 1954 & 0.136 & -0.315 & -0.410 & 0.775 \\
\hline & 1976 & 1972 & 0.401 & -2.470 & -0.516 & 3.47 \\
\hline & 1985 & 1981 & 0.327 & 0.684 & 0.165 & 0.191 \\
\hline \multirow[t]{3}{*}{ Colombia $^{\mathrm{e}}$} & 1932 & 1929 & 0.181 & 0.263 & - & -0.090 \\
\hline & 1943 & 1939 & 0.228 & -0.053 & - & 0.041 \\
\hline & 1999 & 1997 & 0.099 & 0.043 & 0.095 & 0.172 \\
\hline \multirow[t]{3}{*}{ India $^{e}$} & 1942 & 1932 & 0.217 & -0.814 & 0.003 & 0.016 \\
\hline & 1946 & 1943 & 0.130 & -0.305 & -0.053 & 0.086 \\
\hline & 1950 & 1947 & 0.177 & 0.504 & -0.025 & 0.038 \\
\hline \multirow[t]{7}{*}{ Malaysia $^{e}$} & 1916 & 1914 & 0.096 & - & - & - \\
\hline & 1920 & 1917 & 0.425 & - & - & - \\
\hline & 1932 & 1929 & 0.258 & - & - & - \\
\hline & 1947 & 1938 & 0.336 & - & - & - \\
\hline & 1952 & 1951 & 0.118 & - & - & 0.164 \\
\hline & 1986 & 1984 & 0.145 & 0.434 & 0.036 & 0.014 \\
\hline & 1998 & 1997 & 0.124 & 0.533 & 0.036 & 0.029 \\
\hline \multirow[t]{5}{*}{ Mexico } & 1916 & 1909 & 0.252 & - & - & $0.031^{\mathrm{k}}$ \\
\hline & 1924 & 1921 & 0.118 & - & - & -0.074 \\
\hline & 1932 & 1926 & 0.311 & $0.406^{\mathrm{m}}$ & - & -0.025 \\
\hline & 1988 & 1981 & 0.161 & -0.148 & 0.024 & 0.852 \\
\hline & 1995 & 1994 & 0.113 & 0.147 & 0.075 & 0.071 \\
\hline \multirow[t]{4}{*}{ Peru } & 1914 & 1907 & 0.118 & - & - & - \\
\hline & 1932 & 1929 & 0.140 & 0.105 & - & -0.043 \\
\hline & 1979 & 1975 & 0.179 & 0.325 & - & 0.437 \\
\hline & 1992 & 1987 & 0.300 & 0.519 & -0.522 & 24.8 \\
\hline \multirow[t]{5}{*}{ Singapore $^{\mathrm{e}}$} & 1916 & 1910 & 0.145 & - & - & - \\
\hline & 1920 & 1918 & 0.127 & - & - & - \\
\hline & 1931 & 1928 & 0.104 & - & - & - \\
\hline & 1951 & 1949 & 0.159 & - & - & 0.098 \\
\hline & 1959 & 1956 & 0.117 & - & - & 0.013 \\
\hline \multirow[t]{3}{*}{ South Korea } & 1945 & 1942 & 0.387 & - & - & - \\
\hline & 1952 & 1949 & 0.371 & - & - & 1.68 \\
\hline & 1998 & 1997 & 0.143 & 0.458 & 0.072 & 0.066 \\
\hline \multirow[t]{3}{*}{ Taiwan } & 1905 & 1903 & 0.219 & - & - & 0.076 \\
\hline & 1911 & 1910 & 0.127 & - & - & 0.082 \\
\hline & 1945 & 1936 & 0.684 & - & - & 0.148 \\
\hline \multirow[t]{3}{*}{ Turkey $^{\mathrm{e}}$} & 1932 & 1929 & 0.120 & - & - & -0.031 \\
\hline & 1946 & 1938 & 0.298 & - & - & 0.215 \\
\hline & 2001 & 2000 & 0.108 & 0.565 & -0.078 & 0.390 \\
\hline \multirow[t]{3}{*}{ Uruguay $^{\mathrm{e}}$} & 1965 & 1960 & 0.099 & - & - & 0.274 \\
\hline & 1984 & 1981 & 0.267 & - & - & 0.338 \\
\hline & 2002 & 1998 & 0.219 & - & - & $\begin{array}{r}0.054 \\
\text { ontinued) }\end{array}$ \\
\hline
\end{tabular}


Table C1. Consumption Disasters (Continued)

\begin{tabular}{|c|c|c|c|c|c|c|}
\hline \multirow[b]{2}{*}{ Country } & \multicolumn{2}{|c|}{ Disaster period } & \multirow{2}{*}{$\begin{array}{l}\text { Decline in } \\
\text { consumer } \\
\text { expenditure } \\
\text { per capita }^{\mathrm{b}}\end{array}$} & \multirow{2}{*}{$\begin{array}{c}\text { Stock- } \\
\text { price } \\
\text { decline }^{\mathrm{c}}\end{array}$} & \multirow{2}{*}{$\begin{array}{l}\text { Rate of } \\
\text { return } \\
\text { on bills }\end{array}$} & \multirow{2}{*}{$\begin{array}{c}\text { Inflation } \\
\text { rate }^{\mathrm{d}}\end{array}$} \\
\hline & Trough $^{\mathrm{a}}$ & Peak & & & & \\
\hline \multirow[t]{6}{*}{ Venezuela $^{e}$} & 1933 & 1930 & 0.311 & 0.074 & 一 & -0.060 \\
\hline & 1936 & 1935 & 0.107 & -0.069 & - & -0.058 \\
\hline & 1952 & 1948 & 0.203 & 0.103 & -0.025 & 0.048 \\
\hline & 1964 & 1957 & 0.223 & 0.329 & 0.020 & 0.016 \\
\hline & 1989 & 1982 & 0.320 & -3.493 & -0.048 & 0.183 \\
\hline & 2003 & 1993 & 0.147 & 0.690 & -0.043 & 0.421 \\
\hline
\end{tabular}

Source: Authors' construction; for details on sources and procedures see the online appendix at www.economics.harvard.edu/faculty/barro/data_sets_barro.

a. Italics indicate that the country was a current participant in an external or internal war.

b. Decline in real personal consumer expenditure per capita by 0.1 or greater, expressed as a cumulative fraction from peak year to trough year.

c. Decline in real stock prices, expressed as cumulative fractions from the end of the year preceding the peak to the end of the year preceding the trough (unless the timing is indicated otherwise because of missing data). Negative numbers indicate increases in real stock prices.

d. Mean values from the peak year to one year before the trough year (unless the timing is indicated otherwise because of missing data).

e. Not included in the analysis for the consumer expenditure sample.

f. 1913-14. g. 1915-17. h. 1937-40. i. 1988-92. j. 1934-35. k. 1909-13. m. 1929-31. 
Table C2. GDP Disasters

\begin{tabular}{|c|c|c|c|c|c|c|}
\hline \multirow[b]{2}{*}{ Country } & \multicolumn{2}{|c|}{ Disaster period } & \multirow{2}{*}{$\begin{array}{c}\text { Decline in } \\
\text { GDP per } \\
\text { capita }^{\mathrm{b}}\end{array}$} & \multirow{2}{*}{$\begin{array}{l}\text { Stock- } \\
\text { price } \\
\text { decline }^{\mathrm{c}}\end{array}$} & \multirow{2}{*}{$\begin{array}{l}\text { Rate of } \\
\text { return } \\
\text { on bills }\end{array}$} & \multirow{2}{*}{$\begin{array}{c}\text { Inflation } \\
\text { rate }^{\mathrm{d}}\end{array}$} \\
\hline & Trough $^{\mathrm{a}}$ & Peak & & & & \\
\hline \multicolumn{7}{|c|}{ OECD countries } \\
\hline \multirow[t]{4}{*}{ Australia } & 1895 & 1889 & 0.271 & 0.067 & 0.085 & -0.050 \\
\hline & 1918 & 1910 & 0.118 & 0.188 & -0.020 & 0.045 \\
\hline & 1931 & 1926 & 0.221 & 0.179 & 0.061 & -0.013 \\
\hline & 1946 & 1943 & 0.145 & -0.167 & 0.007 & 0.005 \\
\hline \multirow[t]{3}{*}{ Austria } & 1918 & 1912 & 0.381 & - & 0.031 & 0.022 \\
\hline & 1933 & 1929 & 0.235 & 0.533 & 0.071 & -0.004 \\
\hline & 1945 & 1941 & 0.587 & - & - & - \\
\hline \multirow[t]{3}{*}{ Belgium } & 1918 & 1913 & 0.477 & - & -0.225 & 0.492 \\
\hline & 1934 & 1930 & 0.117 & 0.451 & 0.070 & -0.052 \\
\hline & 1943 & 1937 & 0.453 & -0.764 & -0.033 & 0.045 \\
\hline \multirow[t]{3}{*}{ Canada } & 1878 & 1874 & 0.117 & - & - & -0.020 \\
\hline & 1921 & 1917 & 0.301 & 0.393 & - & 0.115 \\
\hline & 1933 & 1928 & 0.348 & 0.558 & - & -0.041 \\
\hline \multirow[t]{2}{*}{ Denmark } & 1918 & 1914 & 0.160 & $0.132^{\mathrm{f}}$ & -0.045 & 0.128 \\
\hline & 1941 & 1939 & 0.239 & 0.336 & -0.120 & 0.193 \\
\hline \multirow[t]{4}{*}{ Finland } & 1881 & 1876 & 0.120 & - & - & - \\
\hline & 1918 & 1913 & 0.353 & - & $-0.194^{\mathrm{g}}$ & $0.389^{\mathrm{g}}$ \\
\hline & 1940 & 1938 & 0.103 & 0.142 & 0.017 & 0.024 \\
\hline & 1993 & 1989 & 0.124 & 0.620 & 0.092 & 0.045 \\
\hline \multirow[t]{6}{*}{ France } & 1870 & 1868 & 0.095 & - & - & -0.011 \\
\hline & 1879 & 1874 & 0.102 & - & - & -0.002 \\
\hline & 1886 & 1882 & 0.133 & 0.296 & 0.028 & 0.000 \\
\hline & 1918 & 1912 & 0.289 & 0.395 & -0.055 & 0.117 \\
\hline & 1935 & 1929 & 0.187 & 0.535 & 0.068 & -0.039 \\
\hline & 1944 & 1939 & 0.414 & - & -0.147 & 0.197 \\
\hline \multirow[t]{4}{*}{ Germany } & 1919 & 1913 & 0.357 & 0.736 & -0.125 & 0.214 \\
\hline & 1923 & 1922 & 0.135 & 0.654 & -0.970 & 34.5 \\
\hline & 1932 & 1928 & 0.280 & 0.562 & 0.109 & -0.035 \\
\hline & 1946 & 1943 & 0.736 & 0.068 & -0.009 & 0.028 \\
\hline \multirow[t]{9}{*}{ Greece } & 1872 & 1868 & 0.106 & - & - & - \\
\hline & 1877 & 1873 & 0.152 & - & - & - \\
\hline & 1891 & 1888 & 0.233 & - & - & - \\
\hline & 1897 & 1896 & 0.151 & - & - & - \\
\hline & 1901 & 1899 & 0.144 & - & - & - \\
\hline & 1913 & 1911 & 0.419 & - & - & - \\
\hline & 1919 & 1918 & 0.177 & - & -0.553 & 1.38 \\
\hline & 1923 & 1921 & 0.238 & - & -0.203 & 0.369 \\
\hline & 1942 & 1939 & 0.660 & $0.448^{\mathrm{h}}$ & -0.331 & 4.31 \\
\hline \multirow[t]{4}{*}{ Iceland } & 1883 & 1881 & 0.125 & - & - & - \\
\hline & 1918 & 1913 & 0.221 & - & - & 0.206 \\
\hline & 1920 & 1919 & 0.157 & - & - & 0.114 \\
\hline & 1952 & 1948 & 0.139 & - & - & 0.235 \\
\hline \multirow[t]{2}{*}{ Italy } & 1920 & 1918 & 0.221 & 0.374 & -0.101 & 0.195 \\
\hline & 1945 & 1939 & 0.413 & 0.429 & -0.236 & 1.02 \\
\hline Japan & 1944 & 1940 & 0.503 & 0.239 & -0.026 & $\begin{array}{c}0.054 \\
\text { tinued) }\end{array}$ \\
\hline
\end{tabular}


Table C2. GDP Disasters (Continued)

\begin{tabular}{|c|c|c|c|c|c|c|}
\hline \multirow[b]{2}{*}{ Country } & \multicolumn{2}{|c|}{ Disaster period } & \multirow{2}{*}{$\begin{array}{c}\text { Decline in } \\
\text { GDP per } \\
\text { capita }^{\mathrm{b}}\end{array}$} & \multirow{2}{*}{$\begin{array}{c}\text { Stock- } \\
\text { price } \\
\text { decline }\end{array}$} & \multirow{2}{*}{$\begin{array}{l}\text { Rate of } \\
\text { return } \\
\text { on bills }\end{array}$} & \multirow{2}{*}{$\begin{array}{c}\text { Inflation } \\
\text { rate }^{\mathrm{d}}\end{array}$} \\
\hline & Trough $^{\mathrm{a}}$ & Peak & & & & \\
\hline \multirow{3}{*}{ Netherlands } & 1918 & 1913 & 0.258 & - & -0.021 & 0.070 \\
\hline & 1934 & 1929 & 0.129 & 0.582 & 0.057 & -0.032 \\
\hline & 1944 & 1939 & 0.525 & -0.506 & -0.050 & 0.069 \\
\hline \multirow[t]{6}{*}{ New Zealand } & 1879 & 1878 & 0.174 & - & - & - \\
\hline & 1909 & 1907 & 0.110 & - & - & - \\
\hline & 1918 & 1911 & 0.107 & - & - & 0.040 \\
\hline & 1927 & 1925 & 0.117 & - & 0.057 & 0.009 \\
\hline & 1948 & 1947 & 0.119 & 0.003 & -0.061 & 0.081 \\
\hline & 1951 & 1950 & 0.097 & -0.049 & -0.068 & 0.089 \\
\hline \multirow[t]{3}{*}{ Norway } & 1918 & 1916 & 0.148 & -0.035 & -0.212 & 0.326 \\
\hline & 1921 & 1920 & 0.110 & 0.447 & -0.117 & 0.194 \\
\hline & 1944 & 1939 & 0.193 & -0.222 & -0.062 & 0.090 \\
\hline \multirow[t]{2}{*}{ Portugal } & 1928 & 1927 & 0.109 & - & - & - \\
\hline & 1936 & 1934 & 0.148 & -0.434 & 0.044 & 0.010 \\
\hline \multirow[t]{3}{*}{ Spain } & 1896 & 1892 & 0.119 & -0.088 & 0.079 & -0.024 \\
\hline & 1933 & 1929 & 0.096 & 0.464 & 0.061 & -0.009 \\
\hline & 1938 & 1935 & 0.313 & $0.238^{\mathrm{i}}$ & -0.035 & 0.098 \\
\hline \multirow[t]{3}{*}{ Sweden } & 1918 & 1916 & 0.150 & 0.169 & -0.185 & 0.323 \\
\hline & 1921 & 1920 & 0.108 & 0.251 & 0.052 & 0.019 \\
\hline & 1941 & 1939 & 0.095 & 0.349 & -0.071 & 0.104 \\
\hline \multirow[t]{3}{*}{ Switzerland } & 1879 & 1875 & 0.161 & - & - & - \\
\hline & 1918 & 1912 & 0.191 & 0.475 & -0.031 & 0.088 \\
\hline & 1942 & 1939 & 0.126 & 0.308 & -0.080 & 0.105 \\
\hline \multirow[t]{2}{*}{ United Kingdom } & 1921 & 1918 & 0.192 & 0.321 & -0.069 & 0.130 \\
\hline & 1947 & 1943 & 0.148 & -0.269 & 0.003 & 0.006 \\
\hline \multirow[t]{5}{*}{ United States } & 1908 & 1906 & 0.105 & 0.365 & 0.019 & 0.041 \\
\hline & 1914 & 1913 & 0.095 & 0.160 & 0.034 & 0.020 \\
\hline & 1921 & 1918 & 0.118 & 0.293 & -0.057 & 0.125 \\
\hline & 1933 & 1929 & 0.290 & 0.631 & 0.093 & -0.064 \\
\hline & 1947 & 1944 & 0.165 & -0.061 & -0.062 & 0.076 \\
\hline \multicolumn{7}{|c|}{ Non-OECD countries } \\
\hline \multirow[t]{9}{*}{ Argentina } & 1891 & 1889 & 0.189 & - & - & 0.284 \\
\hline & 1897 & 1896 & 0.219 & - & - & 0.069 \\
\hline & 1900 & 1899 & 0.147 & - & - & -0.096 \\
\hline & 1917 & 1912 & 0.289 & - & - & 0.047 \\
\hline & 1932 & 1929 & 0.195 & - & - & -0.002 \\
\hline & 1959 & 1958 & 0.101 & - & - & 0.507 \\
\hline & 1982 & 1980 & 0.111 & 0.575 & 0.516 & 1.09 \\
\hline & 1990 & 1988 & 0.141 & -3.430 & -0.355 & 26.6 \\
\hline & 2002 & 1998 & 0.220 & 0.401 & 0.090 & -0.009 \\
\hline \multirow[t]{5}{*}{ Brazil } & 1887 & 1884 & 0.105 & - & - & -0.020 \\
\hline & 1893 & 1891 & 0.262 & - & - & 0.248 \\
\hline & 1900 & 1895 & 0.135 & - & - & 0.033 \\
\hline & 1931 & 1928 & 0.201 & - & - & -0.037 \\
\hline & 1992 & 1987 & 0.110 & 0.358 & - & 10.8 \\
\hline
\end{tabular}


Table C2. GDP Disasters (Continued)

\begin{tabular}{|c|c|c|c|c|c|c|}
\hline \multirow[b]{2}{*}{ Country } & \multicolumn{2}{|c|}{ Disaster period } & \multirow{2}{*}{$\begin{array}{c}\text { Decline in } \\
\text { GDP per } \\
\text { capita }^{\mathrm{b}}\end{array}$} & \multirow{2}{*}{$\begin{array}{c}\text { Stock- } \\
\text { price } \\
\text { decline }^{\mathrm{c}}\end{array}$} & \multirow{2}{*}{$\begin{array}{l}\text { Rate of } \\
\text { return } \\
\text { on bills }\end{array}$} & \multirow{2}{*}{$\begin{array}{l}\text { Inflation } \\
\text { rate }^{\mathrm{d}}\end{array}$} \\
\hline & Trough $^{\mathrm{a}}$ & Peak & & & & \\
\hline \multirow{6}{*}{ Chile } & 1903 & 1902 & 0.111 & 0.015 & 0.022 & 0.055 \\
\hline & 1915 & 1912 & 0.105 & 0.185 & 0.000 & 0.090 \\
\hline & 1919 & 1918 & 0.126 & -0.018 & 0.103 & -0.014 \\
\hline & 1932 & 1929 & 0.361 & 0.538 & 0.063 & 0.007 \\
\hline & 1975 & 1971 & 0.240 & -2.081 & -0.479 & 2.67 \\
\hline & 1983 & 1981 & 0.180 & 0.499 & 0.296 & 0.151 \\
\hline Colombia & None & & & & & \\
\hline \multirow[t]{4}{*}{ India } & 1877 & 1875 & 0.154 & - & - & -0.065 \\
\hline & 1896 & 1894 & 0.100 & - & 0.120 & -0.060 \\
\hline & 1918 & 1916 & 0.146 & - & 0.004 & -0.061 \\
\hline & 1948 & 1943 & 0.117 & 0.073 & -0.058 & 0.082 \\
\hline \multirow[t]{3}{*}{ Indonesia } & 1933 & 1930 & 0.114 & 0.406 & - & -0.186 \\
\hline & 1945 & 1940 & 0.545 & - & - & 0.044 \\
\hline & 1999 & 1997 & 0.158 & 0.681 & -0.066 & 0.440 \\
\hline \multirow{5}{*}{ Malaysia $^{e}$} & 1904 & 1902 & 0.100 & - & - & - \\
\hline & 1935 & 1929 & 0.193 & - & - & - \\
\hline & 1937 & 1936 & 0.117 & - & - & - \\
\hline & 1941 & 1939 & 0.235 & - & - & - \\
\hline & 1947 & 1942 & 0.361 & - & - & - \\
\hline \multirow[t]{3}{*}{ Mexico } & 1915 & 1909 & 0.119 & - & - & $0.031^{\mathrm{j}}$ \\
\hline & 1932 & 1926 & 0.314 & $0.406^{\mathrm{k}}$ & - & -0.025 \\
\hline & 1988 & 1981 & 0.128 & -0.148 & 0.024 & 0.852 \\
\hline \multirow[t]{4}{*}{ Peru } & 1932 & 1929 & 0.258 & 0.105 & - & -0.043 \\
\hline & 1979 & 1975 & 0.104 & 0.325 & - & 0.437 \\
\hline & 1983 & 1981 & 0.136 & 0.879 & - & 0.728 \\
\hline & 1992 & 1987 & 0.325 & 0.519 & -0.522 & 24.8 \\
\hline \multirow[t]{5}{*}{ Philippines } & 1904 & 1903 & 0.158 & - & - & 0.234 \\
\hline & 1915 & 1913 & 0.116 & - & - & -0.109 \\
\hline & 1935 & 1929 & 0.134 & - & - & -0.038 \\
\hline & 1946 & 1939 & 0.572 & - & - & - \\
\hline & 1985 & 1982 & 0.187 & 0.736 & -0.050 & 0.285 \\
\hline \multirow[t]{9}{*}{ Singapore $^{e}$} & 1904 & 1902 & 0.214 & - & - & - \\
\hline & 1913 & 1910 & 0.337 & - & - & - \\
\hline & 1916 & 1915 & 0.174 & - & - & - \\
\hline & 1920 & 1917 & 0.235 & - & - & - \\
\hline & 1927 & 1925 & 0.389 & - & - & - \\
\hline & 1932 & 1929 & 0.412 & - & - & - \\
\hline & 1938 & 1937 & 0.151 & - & - & - \\
\hline & 1952 & 1950 & 0.345 & - & - & 0.192 \\
\hline & 1957 & 1956 & 0.113 & - & - & 0.033 \\
\hline \multirow[t]{4}{*}{ South Africa } & 1917 & 1912 & 0.229 & 0.139 & - & 0.031 \\
\hline & 1920 & 1919 & 0.239 & -0.200 & - & 0.009 \\
\hline & 1987 & 1981 & 0.113 & -0.156 & 0.006 & 0.147 \\
\hline & 1993 & 1989 & 0.102 & 0.028 & 0.032 & 0.140 \\
\hline \multirow[t]{2}{*}{ South Korea } & 1919 & 1918 & 0.111 & - & - & - \\
\hline & 1939 & 1938 & 0.104 & - & - & - \\
\hline
\end{tabular}


Table C2. GDP Disasters (Continued)

\begin{tabular}{|c|c|c|c|c|c|c|}
\hline \multirow[b]{2}{*}{ Country } & \multicolumn{2}{|c|}{ Disaster period } & \multirow{2}{*}{$\begin{array}{c}\text { Decline in } \\
\text { GDP per } \\
\text { capita }^{\mathrm{b}}\end{array}$} & \multirow{2}{*}{$\begin{array}{l}\text { Stock- } \\
\text { price } \\
\text { decline }^{\mathrm{c}}\end{array}$} & \multirow{2}{*}{$\begin{array}{l}\text { Rate of } \\
\text { return } \\
\text { on bills }{ }^{\mathrm{d}}\end{array}$} & \multirow{2}{*}{$\begin{array}{c}\text { Inflation } \\
\text { rate }^{\mathrm{d}}\end{array}$} \\
\hline & Trough $^{\mathrm{a}}$ & Peak & & & & \\
\hline & 1945 & 1940 & 0.480 & - & - & - \\
\hline & 1951 & 1949 & 0.151 & - & - & 0.492 \\
\hline \multirow[t]{5}{*}{ Sri Lanka } & 1878 & 1870 & 0.158 & - & - & - \\
\hline & 1886 & 1883 & 0.141 & - & - & - \\
\hline & 1923 & 1913 & 0.138 & - & - & - \\
\hline & 1932 & 1929 & 0.147 & - & - & - \\
\hline & 1946 & 1942 & 0.211 & - & - & 0.147 \\
\hline \multirow[t]{3}{*}{ Taiwan } & 1905 & 1903 & 0.214 & - & - & 0.076 \\
\hline & 1911 & 1910 & 0.114 & - & - & 0.082 \\
\hline & 1945 & 1936 & 0.662 & - & - & 0.148 \\
\hline \multirow[t]{3}{*}{ Turkey $^{\mathrm{e}}$} & 1927 & 1926 & 0.134 & - & - & 0.033 \\
\hline & 1932 & 1931 & 0.122 & - & - & -0.025 \\
\hline & 1945 & 1939 & 0.395 & - & - & 0.283 \\
\hline \multirow[t]{13}{*}{ Uruguay } & 1875 & 1872 & 0.269 & - & - & - \\
\hline & 1881 & 1878 & 0.153 & - & - & - \\
\hline & 1887 & 1886 & 0.140 & - & - & -0.054 \\
\hline & 1890 & 1888 & 0.202 & - & - & 0.181 \\
\hline & 1901 & 1896 & 0.156 & - & - & 0.045 \\
\hline & 1905 & 1904 & 0.122 & - & - & -0.081 \\
\hline & 1915 & 1912 & 0.280 & - & - & 0.057 \\
\hline & 1920 & 1919 & 0.142 & - & - & 0.099 \\
\hline & 1933 & 1930 & 0.367 & - & - & -0.005 \\
\hline & 1943 & 1939 & 0.139 & - & - & 0.033 \\
\hline & 1959 & 1957 & 0.118 & - & - & 0.190 \\
\hline & 1984 & 1981 & 0.236 & - & - & 0.338 \\
\hline & 2002 & 1998 & 0.186 & - & - & 0.054 \\
\hline \multirow[t]{9}{*}{ Venezuela } & 1892 & 1890 & 0.235 & - & - & - \\
\hline & 1897 & 1893 & 0.225 & - & - & - \\
\hline & 1907 & 1903 & 0.134 & - & - & - \\
\hline & 1916 & 1913 & 0.167 & - & - & $0.025^{\mathrm{m}}$ \\
\hline & 1933 & 1930 & 0.162 & 0.074 & - & -0.060 \\
\hline & 1942 & 1939 & 0.155 & -0.134 & - & -0.003 \\
\hline & 1961 & 1957 & 0.152 & 0.270 & 0.007 & 0.020 \\
\hline & 1985 & 1977 & 0.295 & 0.616 & -0.005 & 0.121 \\
\hline & 2003 & 1993 & 0.259 & 0.690 & -0.043 & 0.421 \\
\hline
\end{tabular}

Source: Authors' construction; for details on sources and procedures see the online appendix at www.economics.harvard.edu/faculty/barro/data_sets_barro.

a. Italics indicate that the country was a current participant in an external or internal war.

b. Decline in real GDP per capita by 0.1 or greater, expressed as a cumulative fraction from peak year to trough year.

c. Decline in real stock prices, expressed as a cumulative fraction from the end of the year preceding the peak to the end of the year preceding the trough (unless the timing is indicated otherwise because of missing data). Negative numbers indicate increases in real stock prices.

d. Mean values from the peak year to one year before the trough year (unless the timing is indicated otherwise because of missing data).

e. Not included in the analysis for the GDP sample.

f. 1914-17. g. 1915-17. h. 1938-40. i. 1934-35. j. 1909-13. k. 1929-31. m. 1914-15. 
Table C3. Declines in Consumer Durables during Consumption Crises ${ }^{a}$

\begin{tabular}{|c|c|c|c|c|c|c|c|}
\hline \multirow[b]{3}{*}{ Country } & \multicolumn{4}{|c|}{$\begin{array}{c}\text { Share of nominal durables } \\
\text { in nominal consumer } \\
\text { expenditure per capita }\end{array}$} & \multicolumn{3}{|c|}{$\begin{array}{l}\text { Proportionate decline } \\
\text { in real consumer } \\
\text { expenditure per capita }\end{array}$} \\
\hline & \multicolumn{2}{|c|}{ Trough } & \multicolumn{2}{|c|}{ Peak } & \multirow{2}{*}{$\begin{array}{c}\text { Consumer } \\
\text { expenditure }^{\mathrm{b}}\end{array}$} & \multirow[b]{2}{*}{ Durables } & \multirow{2}{*}{$\begin{array}{l}\text { Nondurables } \\
\text { and services }\end{array}$} \\
\hline & Year & Share & Year & Share & & & \\
\hline \multicolumn{8}{|c|}{ OECD countries } \\
\hline Canada & 1933 & 0.054 & 1929 & 0.085 & 0.230 & 0.507 & 0.201 \\
\hline \multirow[t]{5}{*}{ Finland } & 1892 & 0.029 & 1890 & 0.042 & 0.102 & 0.132 & 0.101 \\
\hline & 1918 & 0.010 & 1913 & 0.017 & 0.360 & 0.655 & 0.353 \\
\hline & 1932 & 0.013 & 1928 & 0.030 & 0.199 & 0.636 & 0.182 \\
\hline & 1944 & 0.019 & 1938 & 0.038 & 0.254 & 0.634 & 0.237 \\
\hline & 1993 & 0.072 & 1989 & 0.138 & 0.140 & 0.512 & 0.062 \\
\hline \multirow[t]{3}{*}{ Iceland } & 1969 & 0.101 & 1967 & 0.133 & 0.118 & 0.321 & 0.087 \\
\hline & 1975 & 0.134 & 1974 & 0.181 & 0.107 & 0.340 & 0.043 \\
\hline & 1993 & 0.102 & 1987 & 0.183 & 0.176 & 0.529 & 0.053 \\
\hline Portugal & 1976 & 0.092 & 1974 & 0.101 & 0.098 & 0.195 & 0.091 \\
\hline \multirow[t]{6}{*}{ Spain } & 1896 & 0.020 & 1892 & 0.018 & 0.182 & 0.063 & 0.185 \\
\hline & 1915 & 0.020 & 1913 & 0.034 & 0.128 & 0.405 & 0.109 \\
\hline & 1930 & 0.045 & 1929 & 0.057 & 0.101 & 0.238 & 0.090 \\
\hline & 1937 & 0.022 & 1935 & 0.034 & 0.461 & 0.642 & 0.450 \\
\hline & 1945 & 0.023 & 1940 & 0.019 & 0.145 & -0.206 & 0.153 \\
\hline & 1949 & 0.025 & 1946 & 0.027 & 0.131 & 0.170 & 0.127 \\
\hline United & 1918 & 0.040 & 1915 & 0.037 & 0.167 & 0.198 & 0.166 \\
\hline Kingdom & 1943 & 0.023 & 1938 & 0.049 & 0.169 & 0.649 & 0.144 \\
\hline United & 1921 & 0.094 & 1917 & 0.094 & 0.164 & 0.227 & 0.158 \\
\hline States & 1933 & 0.076 & 1929 & 0.119 & 0.208 & 0.501 & 0.169 \\
\hline \multicolumn{8}{|c|}{ Non-OECD countries } \\
\hline Chile & 1985 & 0.060 & 1981 & 0.098 & 0.327 & 0.695 & 0.179 \\
\hline Colombia & 1999 & 0.088 & 1997 & 0.110 & 0.099 & 0.314 & 0.060 \\
\hline Mexico & 1995 & 0.070 & 1994 & 0.082 & 0.113 & 0.340 & 0.077 \\
\hline South Korea & 1998 & 0.063 & 1997 & 0.089 & 0.143 & 0.363 & 0.096 \\
\hline Turkey & 2001 & 0.150 & 2000 & 0.195 & 0.108 & 0.315 & 0.056 \\
\hline \multirow[t]{3}{*}{ Venezuela } & 1964 & 0.042 & 1957 & 0.079 & 0.223 & 0.581 & 0.184 \\
\hline & 1989 & 0.047 & 1982 & 0.073 & 0.320 & 0.643 & 0.299 \\
\hline & 2003 & 0.076 & 1993 & 0.081 & 0.147 & 0.478 & 0.105 \\
\hline Overall means & & 0.058 & & 0.080 & 0.183 & 0.396 & 0.151 \\
\hline
\end{tabular}

a. This table shows the universe of consumption crises considered in table $\mathrm{C} 1$ for which we have been able to break down the decline in real personal consumer expenditure per capita into durables, on the one hand, and nondurables and services, on the other. The latter category should be closer to "consumption." Of the twenty-eight consumer expenditure crises for which the necessary data are available, twenty are included in our main sample of ninety-five crises in table $\mathrm{C} 1$.

b. From table C1. 
Table C4. Consumption Disasters Gauged by One-Sided Hodrick-Prescott Filters ${ }^{\mathrm{a}}$

\begin{tabular}{|c|c|c|c|}
\hline \multirow[b]{2}{*}{ Country } & \multicolumn{2}{|c|}{ Disaster period } & \multirow{2}{*}{$\begin{array}{c}\text { Decline in real } \\
\text { personal consumer } \\
\text { expenditure per capita }\end{array}$} \\
\hline & Trough ${ }^{\mathrm{b}}$ & Peak & \\
\hline \multicolumn{4}{|l|}{ OECD countries } \\
\hline \multirow[t]{3}{*}{ Australia } & 1920 & 1913 & 0.202 \\
\hline & 1935 & 1928 & 0.167 \\
\hline & 1945 & 1938 & 0.215 \\
\hline Belgium & 1944 & 1938 & 0.505 \\
\hline \multirow[t]{2}{*}{ Canada } & 1923 & 1913 & 0.166 \\
\hline & 1935 & 1930 & 0.136 \\
\hline Denmark & 1943 & 1939 & 0.202 \\
\hline \multirow[t]{3}{*}{ Finland } & 1919 & 1913 & 0.201 \\
\hline & 1933 & 1929 & 0.105 \\
\hline & 1944 & 1939 & 0.181 \\
\hline \multirow[t]{3}{*}{ France } & 1874 & 1864 & 0.104 \\
\hline & 1918 & 1913 & 0.185 \\
\hline & 1944 & 1934 & 0.530 \\
\hline \multirow[t]{2}{*}{ Germany } & 1920 & 1913 & 0.384 \\
\hline & 1947 & 1940 & 0.356 \\
\hline Iceland ${ }^{\mathrm{c}}$ & 1995 & 1988 & 0.096 \\
\hline Italy & 1946 & 1940 & 0.221 \\
\hline \multirow{2}{*}{ Japan } & 1936 & 1928 & 0.123 \\
\hline & 1946 & 1937 & 0.515 \\
\hline \multirow{2}{*}{ Netherlands } & 1919 & 1913 & 0.264 \\
\hline & 1944 & 1934 & 0.487 \\
\hline Norway & \multicolumn{2}{|c|}{ None } & \\
\hline Portugal & \multicolumn{2}{|c|}{ None } & \\
\hline Spain & 1939 & 1929 & 0.416 \\
\hline Sweden & 1945 & 1940 & 0.106 \\
\hline Switzerland & 1945 & 1940 & 0.142 \\
\hline \multirow[t]{2}{*}{ United Kingdom } & 1918 & 1915 & 0.109 \\
\hline & 1944 & 1939 & 0.160 \\
\hline United States & 1934 & 1929 & 0.136 \\
\hline \multicolumn{4}{|c|}{ Non-OECD countries } \\
\hline \multirow[t]{3}{*}{ Argentina } & 1933 & 1929 & 0.141 \\
\hline & 1990 & 1980 & 0.168 \\
\hline & 2004 & 2000 & 0.149 \\
\hline Brazil & 1992 & 1985 & 0.158 \\
\hline \multirow[t]{4}{*}{ Chile } & 1917 & 1913 & 0.198 \\
\hline & 1933 & 1930 & 0.247 \\
\hline & 1978 & 1973 & 0.320 \\
\hline & 1987 & 1981 & 0.157 \\
\hline Colombia $^{\mathrm{c}}$ & 1945 & 1941 & 0.095 \\
\hline India $^{c}$ & 1942 & 1933 & 0.184 \\
\hline \multirow[t]{2}{*}{ Malaysia ${ }^{c}$} & 1922 & 1917 & 0.297 \\
\hline & 1934 & 1930 & 0.141 \\
\hline
\end{tabular}


Table C4. Consumption Disasters Gauged by One-Sided Hodrick-Prescott Filters ${ }^{a}$ (Continued)

\begin{tabular}{|c|c|c|c|}
\hline \multirow[b]{2}{*}{ Country } & \multicolumn{2}{|c|}{ Disaster period } & \multirow{2}{*}{$\begin{array}{c}\text { Decline in real } \\
\text { personal consumer } \\
\text { expenditure per capita }\end{array}$} \\
\hline & Trough $^{\mathrm{b}}$ & Peak & \\
\hline \multirow[t]{3}{*}{ Mexico } & 1916 & 1909 & 0.194 \\
\hline & 1934 & 1926 & 0.240 \\
\hline & 1988 & 1982 & 0.115 \\
\hline \multirow{3}{*}{ Peru } & 1914 & 1909 & 0.095 \\
\hline & 1985 & 1976 & 0.205 \\
\hline & 1993 & 1988 & 0.229 \\
\hline Singapore $^{c}$ & 1916 & 1910 & 0.103 \\
\hline \multirow[t]{2}{*}{ South Korea } & 1947 & 1942 & 0.325 \\
\hline & 1952 & 1949 & 0.127 \\
\hline Taiwan & 1947 & 1937 & 0.578 \\
\hline Turkey $^{\mathrm{c}}$ & 1946 & 1940 & 0.222 \\
\hline \multirow[t]{2}{*}{ Uruguay $^{c}$} & 1985 & 1981 & 0.189 \\
\hline & 2004 & 2000 & 0.134 \\
\hline \multirow[t]{3}{*}{ Venezuela $^{c}$} & 1933 & 1930 & 0.499 \\
\hline & 1971 & 1961 & 0.148 \\
\hline & 1990 & 1982 & 0.331 \\
\hline
\end{tabular}

Source: Authors' construction; for details on sources and procedures see the online appendix at www.economics.harvard.edu/faculty/barro/data_sets_barro.

a. Analysis is based on one-sided Hodrick-Prescott filters for the logarithm of real consumer expenditure per capita, using a conventional smoothing parameter of 100. Declines are expressed as cumulative fractions from peak year to trough year.

b. Italics indicate that the country was a current participant in an external or internal war.

c. Not included in the analysis for the consumer expenditure sample. 
Table C5. GDP Disasters Gauged by One-Sided Hodrick-Prescott Filters

\begin{tabular}{|c|c|c|c|}
\hline \multirow[b]{2}{*}{ Country } & \multicolumn{2}{|c|}{ Disaster period } & \multirow{2}{*}{$\begin{array}{l}\text { Decline in real } \\
G D P \text { per capita }\end{array}$} \\
\hline & Trough & Peak & \\
\hline \multirow[t]{3}{*}{ Australia } & 1897 & 1891 & 0.255 \\
\hline & 1920 & 1913 & 0.109 \\
\hline & 1933 & 1928 & 0.163 \\
\hline \multirow[t]{3}{*}{ Austria } & 1920 & 1913 & 0.346 \\
\hline & 1936 & 1930 & 0.226 \\
\hline & 1947 & 1943 & 0.455 \\
\hline \multirow[t]{3}{*}{ Belgium } & 1919 & 1913 & 0.436 \\
\hline & 1935 & 1930 & 0.108 \\
\hline & 1945 & 1938 & 0.426 \\
\hline \multirow[t]{2}{*}{ Canada } & 1922 & 1917 & 0.191 \\
\hline & 1935 & 1930 & 0.250 \\
\hline Denmark & 1943 & 1939 & 0.165 \\
\hline Finland & 1919 & 1914 & 0.225 \\
\hline \multirow[t]{3}{*}{ France } & 1919 & 1913 & 0.208 \\
\hline & 1938 & 1930 & 0.180 \\
\hline & 1945 & 1939 & 0.310 \\
\hline \multirow[t]{3}{*}{ Germany } & 1920 & 1913 & 0.321 \\
\hline & 1933 & 1929 & 0.172 \\
\hline & 1949 & 1944 & 0.663 \\
\hline \multirow[t]{4}{*}{ Greece } & 1872 & 1862 & 0.200 \\
\hline & 1898 & 1888 & 0.174 \\
\hline & 1917 & 1912 & 0.260 \\
\hline & 1945 & 1939 & 0.626 \\
\hline Iceland & 1921 & 1915 & 0.189 \\
\hline Italy & 1946 & 1940 & 0.267 \\
\hline Japan & 1949 & 1943 & 0.439 \\
\hline \multirow[t]{3}{*}{ Netherlands } & 1919 & 1914 & 0.174 \\
\hline & 1935 & 1930 & 0.128 \\
\hline & 1945 & 1939 & 0.426 \\
\hline \multirow[t]{2}{*}{ New Zealand } & 1888 & 1879 & 0.116 \\
\hline & 1933 & 1925 & 0.125 \\
\hline Norway & 1945 & 1939 & 0.115 \\
\hline Portugal & \multicolumn{2}{|c|}{ None } & \\
\hline Spain & 1939 & 1930 & 0.316 \\
\hline Sweden & 1921 & 1916 & 0.131 \\
\hline \multirow[t]{3}{*}{ Switzerland } & 1883 & 1876 & 0.110 \\
\hline & 1919 & 1912 & 0.132 \\
\hline & 1944 & 1934 & 0.127 \\
\hline \multirow[t]{2}{*}{ United Kingdom } & 1923 & 1918 & 0.143 \\
\hline & 1949 & 1944 & 0.109 \\
\hline United States & 1934 & 1929 & 0.221 \\
\hline \multicolumn{4}{|c|}{ Non-OECD countries } \\
\hline \multirow[t]{4}{*}{ Argentina } & 1918 & 1912 & 0.248 \\
\hline & 1934 & 1929 & 0.135 \\
\hline & 1990 & 1980 & 0.201 \\
\hline & 2003 & 1999 & 0.113 \\
\hline
\end{tabular}


Table C5. GDP Disasters Gauged by One-Sided Hodrick-Prescott Filters (Continued)

\begin{tabular}{|c|c|c|c|}
\hline \multirow[b]{2}{*}{ Country } & \multicolumn{2}{|c|}{ Disaster period } & \multirow{2}{*}{$\begin{array}{l}\text { Decline in real } \\
G D P \text { per capita }\end{array}$} \\
\hline & Trough & Peak & \\
\hline Brazil & 1900 & 1891 & 0.175 \\
\hline \multirow[t]{2}{*}{ Chile } & 1933 & 1930 & 0.201 \\
\hline & 1977 & 1972 & 0.170 \\
\hline India & 1950 & 1943 & 0.103 \\
\hline Indonesia & 1947 & 1941 & 0.517 \\
\hline Malaysia $^{\mathrm{c}}$ & 1941 & 1931 & 0.184 \\
\hline \multirow[t]{2}{*}{ Mexico } & 1915 & 1910 & 0.105 \\
\hline & 1934 & 1926 & 0.243 \\
\hline \multirow[t]{3}{*}{ Peru } & 1933 & 1929 & 0.137 \\
\hline & 1985 & 1976 & 0.142 \\
\hline & 1993 & 1987 & 0.269 \\
\hline Philippines & 1988 & 1983 & 0.171 \\
\hline \multirow[t]{3}{*}{ Singapore $^{c}$} & 1916 & 1911 & 0.212 \\
\hline & 1928 & 1925 & 0.153 \\
\hline & 1932 & 1930 & 0.178 \\
\hline South Africa & 1994 & 1984 & 0.156 \\
\hline South Korea & 1952 & 1942 & 0.486 \\
\hline Sri Lanka & 1923 & 1914 & 0.107 \\
\hline Taiwan & 1947 & 1938 & 0.594 \\
\hline Turkey $^{\mathrm{c}}$ & 1945 & 1940 & 0.276 \\
\hline \multirow[t]{6}{*}{ Uruguay } & 1901 & 1896 & 0.112 \\
\hline & 1917 & 1913 & 0.176 \\
\hline & 1935 & 1930 & 0.210 \\
\hline & 1967 & 1957 & 0.169 \\
\hline & 1986 & 1981 & 0.171 \\
\hline & 2003 & 2000 & 0.105 \\
\hline \multirow[t]{4}{*}{ Venezuela } & 1901 & 1895 & 0.109 \\
\hline & 1963 & 1958 & 0.101 \\
\hline & 1989 & 1979 & 0.298 \\
\hline & 2003 & 1993 & 0.157 \\
\hline
\end{tabular}

Source: Authors' construction; for details on sources and procedures see the online appendix at www.economics.harvard.edu/faculty/barro/data_sets_barro.

a. Analysis is based on one-sided Hodrick-Prescott filters for the logarithm of real GDP per capita, using a conventional smoothing parameter of 100 . Declines by 0.1 or greater are expressed as cumulative fractions from peak year to trough year.

b. Italics indicate that the country was a current participant in an external or internal war.

c. Not included in the analysis for the GDP sample. 
APPENDIX D

\section{Distributions of Disasters Using}

Hodrick-Prescott-Filtered Data

Figure D1. Distributions of Consumer Expenditure Disasters by Size and Duration, One-Sided HP-Filtered ${ }^{a}$

No. of events

By size

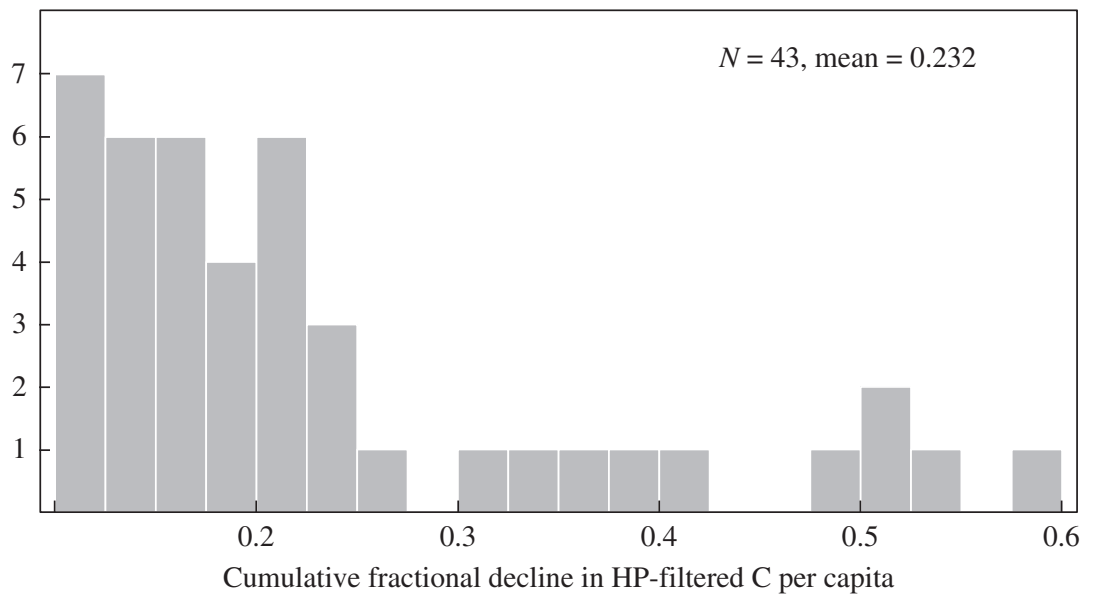

No. of events

By duration

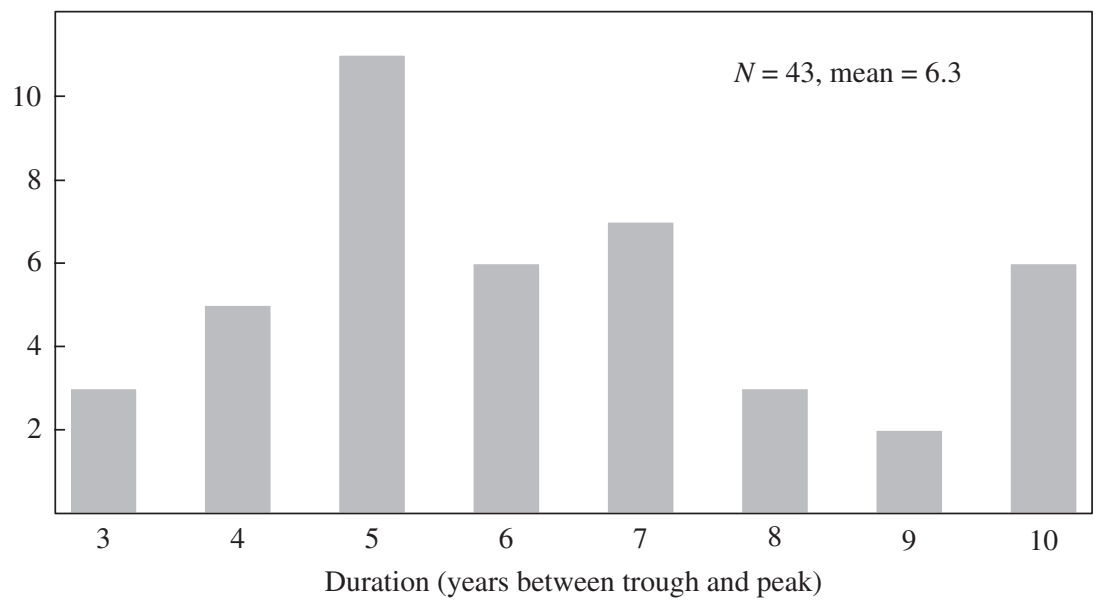

Source: Authors' calculation; for details on sources and procedures see the online appendix at www.economics.harvard.edu/faculty/barro/data_sets_barro.

a. The sample is the forty-three personal consumption expenditure disasters listed in table $\mathrm{C} 4$ in appendix C. 
Figure D2. Distributions of GDP Disasters by Size and Duration, One-Sided HP-Filtered ${ }^{a}$

No. of events

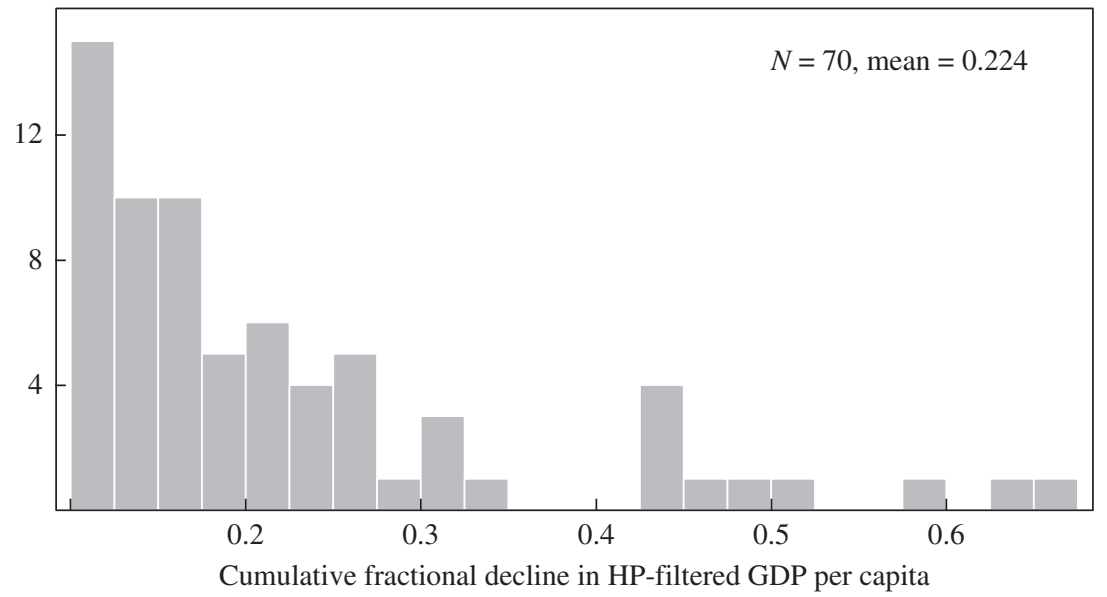

No. of events

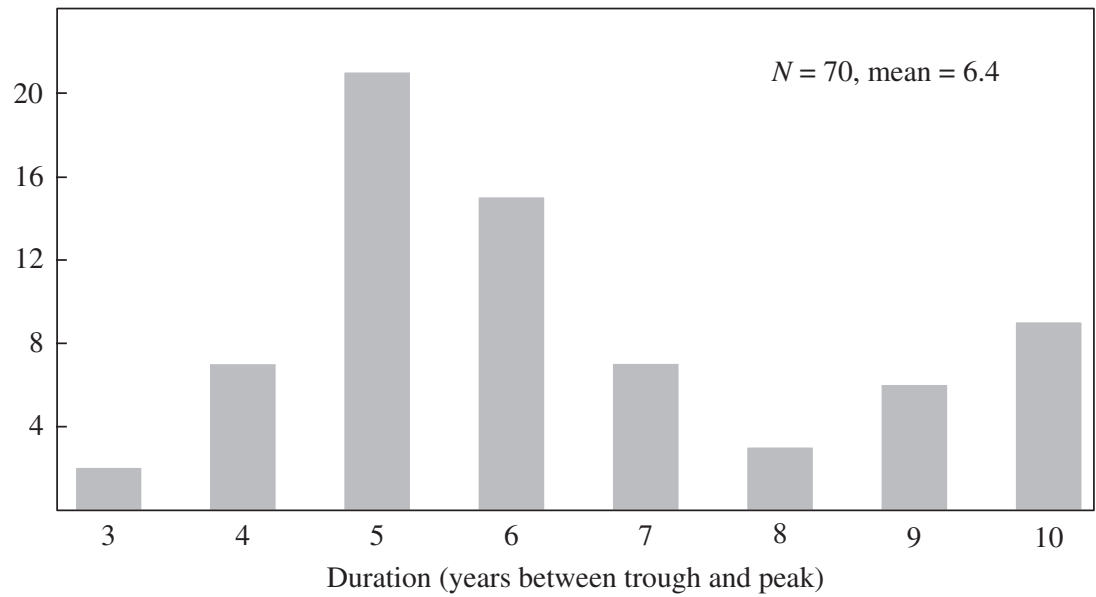

Source: Authors' calculation; for details on sources and procedures see the online appendix at www.economics.harvard.edu/faculty/barro/data_sets_barro.

a. The sample is the seventy GDP disasters listed as in the sample in table C5 in appendix C. 


\section{References}

Balke, Nathan S., and Robert J. Gordon. 1989. "The Estimation of Prewar Gross National Product: Methodology and New Evidence." Journal of Political Economy 97, no. 1: 38-92.

Bansal, Ravi, and Amir Yaron. 2004. "Risks for the Long Run: A Potential Resolution of Asset-Pricing Puzzles." Journal of Finance 59, no. 4: 1481-1509.

Barro, Robert J. 2006. "Rare Disasters and Asset Markets in the Twentieth Century." Quarterly Journal of Economics 121, no. 3: 823-66.

- 2008. Macroeconomics: A Modern Approach. Mason, Ohio: Thomson South-Western.

—. Forthcoming. "Rare Disasters, Asset Prices, and Welfare Costs." American Economic Review.

Cagan, Phillip. 1965. Determinants and Effects of Changes in the Stock of Money, 1875-1960. Columbia University Press.

Caselli, Francesco, and Jaume Ventura. 2000. “A Representative Consumer Theory of Distribution." American Economic Review 90, no. 4: 909-26.

Chatterjee, Satyajit, and Dean Corbae. 2007. "On the Aggregate Welfare Cost of Great Depression Unemployment." Journal of Monetary Economics 54, no. 6: 1529-44.

Cogley, Timothy. 1990. "International Evidence on the Size of the Random Walk in Output." Journal of Political Economy 98, no. 3: 501-18.

Cogley, Timothy, and Thomas J. Sargent. 2008. "The Market Price of Risk and the Equity Premium: A Legacy of the Great Depression?" Journal of Monetary Economics 55, no. 3: 454-76.

Dimson, Elroy, Paul Marsh, and Mike Staunton. 2008. "The Worldwide Equity Premium: A Smaller Puzzle." In Handbook of the Equity Risk Premium, edited by Rajnish Mehra. Amsterdam: Elsevier.

Epstein, Larry G., and Stanley E. Zin. 1989. "Substitution, Risk Aversion, and the Temporal Behavior of Consumption and Asset Returns: A Theoretical Framework." Econometrica 57, no. 4: 937-69.

Fama, Eugene F. 1965. "The Behavior of Stock Market Prices." Journal of Business 38, no. 1: 34-105.

Fujino, Shozaburo, and Ryoko Akiyama. 1977. Security Prices and Rates of Interest in Japan: 1874-1975. Tokyo: Hitotsubashi University.

Gabaix, Xavier. 1999. “Zipf's Law for Cities: An Explanation.” Quarterly Journal of Economics 114, no. 3: 739-67.

—. 2008. "Variable Rare Disasters: An Exactly Solved Framework for Ten Puzzles in Macro-Finance." Working Paper 13724. Cambridge, Mass.: National Bureau of Economic Research (January).

Gabaix, X., and Rustam Ibragimov. 2007. "Rank-1/2: A Simple Way to Improve the OLS Estimation of Tail Exponents." Technical Working Paper 342. Cambridge, Mass.: National Bureau of Economic Research (September). 
Lucas, Robert E., Jr. 1978. "Asset Prices in an Exchange Economy.” Econometrica 46, no. 6: 1429-45.

Maddison, Angus. 2003. The World Economy: Historical Statistics. Paris: Organization for Economic Cooperation and Development.

Mandelbrot, Benoit. 1963. "The Variation of Certain Speculative Prices." Journal of Business 36, no. 4: 394-419.

Mehra, Rajnish, and Edward C. Prescott. 1985. "The Equity Premium: A Puzzle." Journal of Monetary Economics 15, no. 2: 145-61.

Rietz, Thomas A. 1988. "The Equity Risk Premium: A Solution.” Journal of Monetary Economics 22, no. 1: 117-31.

Romer, Christina D. 1986. "Is the Stabilization of the Postwar Economy a Figment of the Data?" American Economic Review 76, no. 3: 314-34.

Taylor, Bryan. 2005. "GFD Guide to Total Returns on Stocks, Bonds and Bills." Los Angeles: Global Financial Data. www.globalfinancialdata.com/articles/ total_return_guide.doc

Ursúa, J. F. 2008. "The 1921 World Recession: Was It World War I or the Flu?" Harvard University.

Weil, Philippe. 1990. "Nonexpected Utility in Macroeconomics." Quarterly Journal of Economics 105, no. 1: 29-42.

Weitzman, Martin L. 2007. "Subjective Expectations and Asset-Return Puzzles." American Economic Review 97, no. 4: 1102-30. 


\section{Comments and Discussion}

\section{COMMENT BY}

OLIVIER J. BLANCHARD Even if one is not deeply interested in the equity premium puzzle, this paper by Robert Barro and José Ursúa will prove extremely useful. Understanding the economic implications of disasters, whether natural or man-made, is both essential and fascinating. Like the celebrated Barro-Lee growth dataset, the dataset that the authors have carefully put together for this project will be widely used. I had fun playing with it, and so will others.

I shall organize my comments around two points. The first is that macroeconomic crises-what the authors call consumption and GDP disasterscome in very different forms, with different implications for output, consumption, and rates of return on bills, bonds, and stocks. The second is that if the focus is on the equity premium, and if one takes seriously the claim that the authors have now provided a representative sample of disasters, then looking at the determination of the equity premium through the lens of the Lucas model does not seem the best way to proceed.

THE MANY INCARNATIONS OF CONSUMPTION DISASTERS What I was most struck by, looking at the consumption disasters identified and documented by the authors, was how different these disasters in fact were one from another. As I went through the list, it became fairly clear that the disasters should be put in different boxes. Here is a tentative breakdown.

Wars on one's own soil. For obvious reasons, a war on one's own soil leads to a large decline in output and consumption. Part of the country is occupied by the enemy, and production in the rest is seriously disrupted.

I thank Antoine Bozio for information about the French stock market, Pedro Portugal for information about the Portuguese stock market, and the authors for providing me with their data. 
The stock market, if it remains open, does poorly. Depending on the extent of rationing, inflation may be high; real bill returns are likely to be low.

A good example is France during World War II. From 1937 to 1944, output per capita in France decreased by 51 percent (using log differences); not until 1947 did it return to its 1937 level. From 1938 to 1943, consumption per capita decreased by 86 percent (this seems extremely large); not until 1949 did it return to its 1938 level. $^{1}$

The German invasion closed the stock market. It reopened under the Vichy regime, but, not surprisingly, volume remained very low during the war. ${ }^{2}$ (This raises the issue of what one should assume for stock returns when the market is closed. Could one reasonably argue that if one cannot sell one's stock, the rate of return in such years is -100 percent?) Leaving 1940 and 1941 aside, the average yearly rate of return on stocks from 1938 to 1947 was -10 percent.

Despite widespread rationing, average inflation in France during the war was high. From 1938 to 1944, annual inflation as measured by the consumer price index averaged 18.7 percent, leading to large negative bill and bond returns. (Rationing also raises the issue of whether it makes sense to use the first-order condition of consumers. This condition relies on a thought experiment in which a larger return on the asset allows one to increase consumption at the margin, but such an increase may not feasible under rationing.) As is often the case, the immediate postwar period was associated with a burst of inflation, leading to even larger negative bill and bond returns. Inflation from 1945 to 1948 averaged 58.7 percent, and bill and bond returns were negative and very large.

Wars on foreign soil. Wars on foreign soil have a very different economic profile. With the increase in defense spending, output is likely to increase, but its composition is likely to change drastically. Whether through rationing or through other means, consumption is likely to fall. After the initial bad news that a war is imminent, the stock market, pushed by defense stocks, is likely to do well. Depending on the form of rationing and the extent of forced saving, inflation is likely to rise, while nominal rates of return are kept low, leading to negative real bond returns.

The standard example here is the United States during World War II. From 1941 to 1945, U.S. output per capita grew by 34 percent. Consumption per capita dipped by 3 percent from 1941 to 1942 but was still 5 percent

1. All the numbers on GDP, consumption, and stock and bond returns cited in this comment are from the Barro-Ursúa database.

2. The authors assume that it was closed during both 1940 and 1941. My French historian friends tell me that it was closed only for a few weeks in 1940. 
higher in 1945 than in 1941. The small consumption decrease in 1942 is not large enough to make the authors' "consumption disaster" list. Interestingly (and I return to this below), the United States does make the "GDP disaster" list in the 1940s, but, perhaps surprisingly, for the period 1944 to 1947, which includes the first two postwar years. The reason is the return of the U.S. economy from the wartime boom to a more normal level of output.

With the boom and the increase in defense spending, U.S. stock returns were high during the war. From 1941 to 1945 , annual stock returns averaged 12 percent; from 1942 to 1945, they averaged 20.9 percent. Despite price controls, inflation ran at an average 5 percent a year from 1941 to 1945. Coupled with very low nominal interest rates aimed at limiting the burden of increasing government debt, the result was negative rates of return on government bonds. As in France, the immediate aftermath of the war was characterized by a burst of inflation, which reached 18 percent in 1946, leading to large negative returns on nominal assets.

Civil wars. Civil wars offer yet another pattern of co-movements among output, consumption, and stock and bond returns. A leftist revolution, for example, may lead to an initial shift in income distribution and an initial increase in consumption, followed later by lower output and lower consumption. Companies are likely to be nationalized, and stock returns are likely to suffer. Loss of government revenue is likely to lead to rapid money growth, high inflation, and large losses on nominal assets.

Portugal provides a nice example. In 1974, after a long dictatorship and the loss of Portugal's colonies, a bloodless coup put leftist colonels in charge. Political and economic turmoil ensued, together with large-scale nationalization of firms. Although output decreased marginally from 1973 to 1974 , consumption increased by 7 percent (one may, however, reasonably question whether the consumption of stockholders increased as well). The measured labor share of income exceeded 100 percent of GDP, and so it is no great surprise that both output and consumption declined in the following years. Not until 1978 did they exceed their 1973 level.

Not surprisingly, the Portuguese stock market did not do well. The market was closed from April 1974 to February 1977. Measured stock returns were negative and large in 1978. But bill returns did not fare much better. Inflation averaged 20 percent a year from 1974 to 1978 and remained above 20 percent until 1985 . Nominal interest rates were substantially lower, implying large negative real returns.

Other types of crisis, and some implications. One could go on. Another box would include fiscal crises. Fiscal crises accompanied by hyperinflations are likely to feature low output and low consumption. Stock returns 
may be dismal, but so are bill and bond returns. Here the German hyperinflation of 1923 is the obvious example. During this consumption disaster, as defined by the authors' dates, stock prices declined by 65.4 percent. But the real rate of return on bills was -97 percent. Another box would include banking crises, such as that in Finland in the early 1990s, and so on.

In going through these cases, I have done what Barro and Ursúa precisely do not want us to do. I have tried to think about each data point and told a specific story. The authors' interest is in general patterns and the use of a large sample of disasters to uncover them. This makes sense, however, only if all these disasters are realizations from the same underlying process. This seems unlikely. Conditioning on the probability of a war at home will not imply the same set of conditional correlations as conditioning on a war fought abroad; they imply very different patterns of correlations. And if the probabilities of these different events vary across countries and time, the implications of an unconditional approach are likely to be misleading.

To take an example, and venturing further than I should, it is likely that in the United States the probability of a war at home (say, the explosion of an atomic bomb) has decreased with the end of the cold war (conventional terrorism, including the use of "dirty" bombs, is unlikely to create disasters on the same scale). But one may argue that the probability of a war abroad has increased. One may also argue that the probabilities of a hyperinflation or a financial crisis have changed substantially over time. If this is the case, then the unconditional equity premium derived by the authors is likely to be misleading.

DO WE NEED THE LUCAS-TREE MODEL? Having collected their data, Barro and Ursúa analyze the data through the lens of a Lucas-tree model, augmented for a small annual probability of disaster à la Thomas Rietz. This requires them to estimate the probability of a disaster, $p$, and the size of the relative consumption disaster, $b$.

I do not understand why the authors force themselves to look at the data through this particular straightjacket. Doing so forces them to choose dates for the start and the end of each disaster, to ignore the length of the disaster, to make assumptions about returns on bills, and so on. The way in which they map the data onto the inputs of the model is sensible, and given the mapping constraint, they do the best job that one can, but the results are sometimes surprising. The choice, for example, of a peak-to-trough fractional decline larger than 10 percent as a criterion for consumption or GDP disasters seems perfectly reasonable. But it leads, for example, to defining a consumption disaster for France from 1938 to 1943, even though con- 
sumption remained below its 1938 value until 1949. (Recall that the high inflation and very low bill returns occurred from 1945 to 1948, thus after the authors' consumption disaster, but before consumption returned to its prewar level. This may be relevant to the way one thinks about asset pricing.) It also leads to defining a GDP disaster for the United States from 1944 to 1947, which might have come as a surprise to participants at the time. Given a mechanical rule, one has to accept the discipline of the rule, and the consequences. The question is whether the rule is needed.

The motivation for using the Lucas-Rietz model until now was twofold. The first was to clarify the potential role of low-probability events in asset pricing; the model is at just the right level between simplicity and complexity to give nontrivial insights. The second was that researchers lacked even a representative sample, much less a universe, of disasters to analyze. Thus one could not be too ambitious in describing correlations during crises, and the simple $p$ and $b$ approach seemed properly humble and transparent.

The point of this paper is, however, to provide a much larger sample, indeed the universe of consumption disasters that one can hope to measure. In this case I see no reason not to go back to asset pricing formulas that rely only on the first-order intertemporal condition of consumers with no additional assumptions. As is well known, this simplified condition can be written, for any asset, as

$$
\mathrm{E}(R)=\left[\frac{1}{\mathrm{E}(M)}\right][1-\operatorname{cov}(M, R)],
$$

where $M$ is the marginal rate of substitution between consumption today and consumption in the next period, $R$ is the gross rate of return on the asset—stocks, bills, or bonds-over the same period, and E(.) is a conditional expectation.

Given a specification of utility and thus of the marginal rate of substitution, that condition can be used to compute conditional or unconditional required returns on stocks, bills, and bonds and the implied equity premium. This computation does not require taking a stand on starting and ending dates for consumption disasters, nor does it require treating bills as riskless. It deals naturally with issues of disaster length, which are central to the computation in the Lucas-Rietz framework. It allows one to explore how the bursts of inflation that often follow consumption disasters are relevant to the equity premium. In short, it seems to simplify the task and to get around a number of the issues that arise under the current formalization. I hope the authors explore this route in the future. 


\section{COMMENT BY}

GEORGE M. CONSTANTINIDES An important contribution of this paper by Robert Barro and José Ursúa is the compilation of a comprehensive database of real growth in consumption per capita for twenty-four countries and in GDP per capita for thirty-six, with data for some countries dating back to 1870 . This database builds upon and greatly expands an earlier one by Angus Maddison on GDP growth and is, in its own right, an invaluable resource for future research. ${ }^{1}$

The paper's second contribution is to employ this database to revisit and expound on earlier investigations by Thomas Rietz and by Barro himself in understanding the role of rare but major economic disasters in the equity premium and the risk-free rate puzzles. ${ }^{2}$ My discussion focuses on the latter contribution.

The equity premium puzzle, to use the term coined by Rajnish Mehra and Edward Prescott, ${ }^{3}$ originally referred to the inability of the standard neoclassical economic theory to reconcile the historically large realized premium of stock market returns over the risk-free interest rate with its low covariability with aggregate consumption growth. ${ }^{4}$ By now it is recognized that the challenge is actually a dual puzzle of the historical equity premium being too high (the equity premium puzzle) and the risk-free rate being too low (the risk-free rate puzzle), relative to the model predictions. The

1. Angus Maddison, The World Economy: Historical Statistics (Paris: Organization for Economic Cooperation and Development, 2003).

2.Thomas A. Rietz, "The Equity Risk Premium: A Solution," Journal of Monetary Economics 22, no. 1 (1988): 117-31; Robert J. Barro, "Rare Disasters and Asset Markets in the Twentieth Century," Quarterly Journal of Economics 121, no. 3 (2006): 823-66. Related papers include Jean-Pierre Danthine and John B. Donaldson, "Non-Falsified Expectations and General Equilibrium Asset Pricing: The Power of the Peso," Economic Journal 109, no. 458(1999): 607-35; Xavier Gabaix, "Variable Rare Disasters: An Exactly Solved Framework for Ten Puzzles in Macro-finance," working paper, New York University, 2007; Christian Julliard and Anisha Ghosh, "Can Rare Events Explain the Equity Premium Puzzle?" working paper, London School of Economics, 2008; and Rajnish Mehra and Edward C. Prescott, “The Equity Premium: A Solution?" Journal of Monetary Economics 22, no. 1 (1988): 133-36.

3. Rajnish Mehra and Edward C. Prescott, "The Equity Premium: A Puzzle," Journal of Monetary Economics 15, no. 2 (1985): 145-61.

4. Early references include Sanford J. Grossman and Robert J. Shiller, "The Determinants of the Variability of Stock Market Prices," American Economic Review 71, no. 2 (1981): 222-27; Lars Peter Hansen and Kenneth J. Singleton, "Generalized Instrumental Variables Estimation of Nonlinear Rational Expectations Models," Econometrica 50, no. 5 (1982): 1269-86; and Philippe Weil, "The Equity Premium Puzzle and the Risk-Free Rate Puzzle," Journal of Monetary Economics 24, no. 3 (1989): 401-21. 
research agenda has subsequently been expanded to encompass a number of empirical regularities in the prices of capital assets that are at odds with the predictions of standard economic theory, notably that the returns of various subclasses of financial assets are too large, too variable, and too predictable. ${ }^{5}$ Several generalizations of essential features of the model have been proposed to mitigate its poor performance. ${ }^{6}$

In particular, Rietz entertained the possibility that rare but major economic disasters cause a large decline in consumption per capita. In theory, the prospect of such disasters gives rise to a significant equity premium, while leaving the risk-free rate low because of the precautionary demand for savings. Rietz calibrated economies that matched both the moments of the time-series process of consumption growth and the unconditional mean of the equity premium and the risk-free rate. He pointed out that the size of the annual (negative) consumption growth at the onset of an economic disaster needed to resolve the puzzle in his calibrated economies is of the same order of magnitude as the (negative) consumption growth over the entire Great Depression. He also pointed out that the model explains only a small fraction of the equity premium if one calibrates the annual (negative) consumption growth at the onset of an economic disaster to annual consumption growth over the Great Depression. ${ }^{7}$ Rietz's model fell by the wayside until recently revived by Barro. ${ }^{8}$

The thesis in that paper and in the present one is that a more careful calibration of the model implies that major economic disasters explain most

5. This extensive literature is reviewed in a collection of essays edited by Rajnish Mehra, Handbooks in Finance: Handbook of the Equity Risk Premium (Amsterdam: Elsevier, 2008); in textbooks by John Y. Campbell, Andrew W. Lo, and A. Craig MacKinlay, The Econometrics of Financial Markets (Princeton University Press, 1997) and by J. H. Cochrane, Asset Pricing (Princeton University Press, 2005); and in several articles, including John Y. Campbell, "Consumption-Based Asset Pricing," in Handbook of the Economics of Finance, vol. IB: Financial Markets and Asset Pricing, edited by George M. Constantinides, Milton Harris, and Rene Stulz, Handbooks in Economics vol. 21 (Amsterdam: NorthHolland, 2003); John H. Cochrane and Lars Peter Hansen, "Asset Pricing Explorations for Macroeconomics," NBER Macroeconomics Annual 7 (1992): 115-65; George M. Constantinides, "Rational Asset Prices," Journal of Finance 57, no. 4 (2002): 1567-91; and Rajnish Mehra and Edward C. Prescott, "The Equity Premium in Retrospect," in Handbook of the Economics of Finance, vol. IB: Financial Markets and Asset Pricing.

6. These include idiosyncratic income shocks in incomplete markets; alternative assumptions about preferences; distorted beliefs and learning; market imperfections; liquidity risk; better understanding of data problems such as limited participation of consumers in the stock market; temporal aggregation; regime shifts; and the survival bias of the U.S. capital market.

7. Barro, "Rare Disasters and Asset Markets in the Twentieth Century." See also the discussion in Mehra and Prescott, "The Equity Premium: A Solution?"

8. Barro, "Rare Disasters and Asset Markets in the Twentieth Century." 
of the observed equity premium. Barro and Ursúa's central argument is that one should calibrate the consumption decrease over the first year of the disaster to the measured cumulative consumption decrease from peak to trough of the disaster period. They motivate this approach with the observation that the incidence of negative shocks to consumption growth increases upon the onset of the economic disaster. Although I recognize the validity of their observation, I explain below why I disagree with their calibration and conclude that a correctly calibrated model, such as that of Rietz, explains only a small fraction of the observed premium.

Before I describe the specifics of the authors' model and discuss it in detail, let me explain in broad terms why I disagree with their central argument. I begin, as they do, with the standard neoclassical economic model, as adapted in finance. In a single-good economy, the representative consumer chooses consumption plan $\left\{C_{t}\right\}_{t=0,1}, \ldots$, subject to a budget constraint, and maximizes expected utility $\mathrm{E}_{0}\left[\sum_{t=0}^{\infty} \beta^{t} C_{t}^{1-\gamma}\right]$ with a constant relative risk aversion coefficient $\gamma$ and a subjective discount factor $\beta .{ }^{9}$ Let $R_{t, t+1}^{j}$ be the total return on the $j^{\text {th }}$ asset from time $t$ to time $t+1$. If $\left(C_{t}, C_{t+1}\right)$ is the optimal consumption plan at times $t$ and $t+1$, then the feasible consumption plan $\left(C_{t}-\delta, C_{t+1}+\delta R_{t, t+1}^{j}\right)$ maximizes expected utility with respect to $\delta$ at $\delta=0$, where $\delta$ is saving in period $t$. This variational argument leads to the standard Euler equation of consumption between times $t$ and $t+1$,

$$
\mathrm{E}_{t}\left[\beta\left(\frac{C_{t+1}}{C_{t}}\right)^{-\gamma} R_{t, t+1}^{j}\right]=1,
$$

as in the authors' equation 4 .

Suppose that time $t$ signifies the onset of an economic disaster. Then the Euler equation between times $t$ and $t+1$ depends on the conditional distribution of consumption growth at time $t, C_{t+1} / C_{t}$, between times $t$ and $t+1$ and on total return, $R_{t, t+1}^{j}$, between times $t$ and $t+1$. Note that this derivation remains valid even if the consumption growth series, $C_{t+1} / C_{t}, C_{t+2} /$ $C_{t+1}, \ldots$, is autocorrelated.

9. Barro and Ursúa also entertain Epstein and Zin preferences; see Larry G. Epstein and Stanley E. Zin, "Substitution, Risk Aversion, and the Temporal Behavior of Consumption and Asset Returns: An Empirical Analysis," Journal of Political Economy 99, no. 2 (1991): 263-86. Their Euler equation 4 holds with Epstein-Zin preferences only if consumption shocks are i.i.d. However, Barro and Ursúa assume that upon the onset of an economic disaster, the shocks are correlated. For their Euler equation 4 to remain valid, it is necessary to limit discussion to utility $\sum_{t=0}^{\infty} \beta^{t} C_{t}^{1-\gamma}$. 
By contrast, Barro and Ursúa argue that upon the onset of an economic disaster, annual consumption growth over the peak-to-trough period of the disaster is highly autocorrelated and that one should replace one-year consumption growth, $C_{t+1} / C_{t}$, in the standard Euler equation with the measured cumulative consumption decrease from peak to trough, for example, $C_{t+4} / C_{t}$ for a four-year decline, as

$$
\mathrm{E}_{t}\left[\beta\left(\frac{C_{t+4}}{C_{t}}\right)^{-\gamma} R_{t, t+1}^{j}\right]=1 .
$$

This is the Euler equation that Barro and Ursúa implicitly apply upon the onset of an economic disaster. They provide no formal derivation of equation 2, and I believe that this equation is incorrect. In a technical sense, this Euler equation concentrates and magnifies the effect of an economic disaster and thus generates a much higher premium than equation 1 does (an observation made earlier by Rietz).

The correct version of the Euler equation with the measured cumulative consumption decrease from peak-to-trough (four-year) consumption growth, $C_{t+4} / C_{t}$, is

$$
\mathrm{E}_{t}\left[\beta\left(\frac{C_{t+4}}{C_{t}}\right)^{-\gamma} R_{t, t+4}^{j}\right]=1 .
$$

This equation states that the Euler equation on four-year consumption growth addresses the four-year return.

As I will show later, the authors' baseline consumption case (the first row in their table 10) says that their model of economic disasters generates a premium of $0.059-0.01$, or 4.9 percent, over 3.6 years. However, the historical equity premium over a holding period of 3.6 years is approximately $3.6 \times 6$ percent $=21.6$ percent. ${ }^{10}$ Thus, the authors' model of economic disasters explains $4.9 \div 21.6 \approx 0.227$, or less than a quarter, of the historical equity premium.

Let me now turn to the authors' formal model. Each year the economy is in either a normal state $(N)$ or a disaster state $(D)$. The sequence of states at the annual frequency is a Markov chain. The transition probability in one year from $N$ to $D$ is $p$ (and that from $N$ to $N$ is $1-p$ ); the transition probability in one year from $D$ to $N$ is $\pi$ (and that from $D$ to $D$ is $1-\pi$ ).

10. See, for example, George M. Constantinides, "Rational Asset Prices," Journal of Finance 57 (August 2002): 1567-91, for estimates of the historical equity premium. 
One easily calculates the unconditional probability of a year being in state $N$ as $P_{N}=\pi /(\pi+p)$ and that of being in state $D$ as $P_{D}=p /(\pi+p)$. The annual probability of the onset of a disaster is $\pi \times p /(\pi+p)$, and the expected length of a disaster is $\pi^{-1}$ years.

In their baseline case, Barro and Ursúa observe that the sample mean length of disasters is 3.6 years. Therefore, I set $\pi=(3.6)^{-1}=0.278$, which agrees with their value of 0.277 in table 10 . They observe 343 disaster years out of a total of 2,963 years across countries. Therefore, I set the unconditional probability of a disaster year as $P_{D}=p /(\pi+p)=343 / 2,963=$ 0.1158 , which, combined with $\pi=0.278$, gives $p=0.0364$. This value of $p$ is approximately equal to the authors' value of 0.0363 in table 10 . Thus, the authors and I are in agreement regarding the calibration of the Markov chain in the baseline case. ${ }^{11}$

Note that the Markov chain and its calibration already accommodate the observation that the incidence of consumption growth shocks is highly correlated during a disaster: whereas the unconditional probability of a disaster year is $P_{D}=0.1158$, the probability conditional on the previous year being a disaster year is $1-\pi=1-0.278=0.722$. I argue later on that Barro and Ursúa double-count this correlation.

Barro and Ursúa assume the following process for annual consumption growth:

$$
\log C_{t+1}-\log C_{t}=g+u_{t+1}+v_{t+1},
$$

where $u_{t+1}, v_{t+1}$ are i.i.d., $u_{t+1} \sim N\left(0, \sigma^{2}\right), v_{t+1}=0$ if $t+1$ is a normal year, and $v_{t+1}=\log (1-b)$ if $t+1$ is a disaster year. If $t$ is a normal year, then the probability that $t+1$ is a normal year is $1-p$, and the probability that it is a disaster year is $p$; if $t$ is a disaster year, then the probability that $t+1$ is a normal year is $\pi$, and the probability that it is a disaster year is $1-\pi$. Thus, Barro and Ursúa model annual consumption growth as a process that is not i.i.d., contrary to their claim: "However, Barro shows that with i.i.d. shocks (as in the present model), the first-order optimizing conditions generate asset pricing equations of familiar form."

Barro and Ursúa set the probability that $u_{t+1}=\log (1-b)$ equal to $p=$ 0.0363 in the baseline. Recall, however, that $p$ was earlier defined as the transition probability in one year from $N$ to $D$. The probability that $v_{t+1}=$ $\log (1-b)$ should be set equal to the unconditional probability of a disaster year, $P_{D}=p /(\pi+p)=0.1158$.

11. Note that this calibration does not account for estimation error and, in particular, the correlation of economic disasters across countries. 
A critical issue is the size of the annual consumption growth shock in a disaster year, $v_{t+1}=\log (1-b)$. Barro and Ursúa assume that the peak-totrough shock occurs in the first year of a disaster. This assumption is not supported by the data over the two primary consumption disaster periods in the United States, 1917-21 and 1929-33. Over 1917-21, the arithmetic annual total real consumption growth, $\left[\left(C_{t+1} / C_{t}\right)-1\right] \times 100$, is -2.6 percent, -3.7 percent, -4.6 percent, and -6.4 percent in $1917-18,1918-19$, 1919-20, and 1920-21, respectively..$^{12}$ The most important feature of these data is that the consumption decline in the first year of the disaster period is the smallest annual decline over the 1917-21 period and accounts for only a fraction of the total consumption decline. Likewise, over the period 1929-33 the arithmetic annual total consumption growth, $\left[\left(C_{t+1} / C_{t}\right)-1\right] \times$ 100 , is -6.4 percent, -3.9 percent, -9.5 percent, and -2.8 percent in 1929 $30,1930-31,1931-32$, and 1932-33, respectively. As before, the consumption decline in the first year of the disaster period accounts for only a fraction of the total consumption decline. Similar observations apply to data on nondurables consumption. These observations do not support the authors' calibration that treats the peak-to-trough consumption decline as if it occurs in the first year of the disaster period.

Given the above observations and the Markovian nature of the authors' model, I proceed to calibrate the fractional decline in annual consumption $b$ if the end of the year is a disaster year. The expected cumulative peak-totrough consumption ratio is

$$
\begin{gathered}
\mathrm{E}\left[\sum_{n=1}^{\infty} \pi(1-\pi)^{n-1}\left(1-b_{1}\right)\left(1-b_{2}\right) \ldots\left(1-b_{n}\right)\right] \\
=\sum_{n=1}^{\infty} \pi(1-\pi)^{n-1}(1-\bar{b})^{n} \\
=\frac{\pi(1-\bar{b})}{1-(1-\pi)(1-\bar{b})} .
\end{gathered}
$$

For this calculation I rely on the authors' assumption that the shocks $\left(1-b_{1}\right)$, $\left(1-b_{2}\right), \ldots,\left(1-b_{n}\right)$ are i.i.d.

12. In private communication, the authors kindly provided the data for total consumption growth and nondurables consumption growth over 1917-21 and 1929-33. I draw similar conclusions by using consumption data on nondurables and services from John Campbell's website (www.economics.harvard.edu/faculty/campbell) and by using consumption data from Robert Shiller's website (www.econ.yale.edu/ shiller/data.htm) that include durables in the definition of consumption. 
In the authors' baseline case, they assume that the expected cumulative trough-to-peak consumption ratio is $1-0.219=0.781$. Setting $\pi(1-\bar{b}) /$ $[1-(1-\pi)(1-\bar{b})]=0.781$ and $\pi=0.278$, I obtain $1-\bar{b}=0.928$. As a back-of-the-envelope calculation, note that with the sample mean length of disasters being 3.6 years, the expected cumulative trough-to-peak consumption ratio is roughly $(0.928)^{3.6}=0.764$, which is very close to 0.781 .

Barro and Ursúa assume for convenience that "equity" or the "stock market" is the claim to the future consumption stream. Effectively, they assume that the capitalized value of future labor income is either zero or included in "equity." This assumption conveniently allows one to bypass the need to specify the conditional return distribution on the equity. Although this assumption is counterfactual, it is a common assumption in the early literature on the equity premium and I leave it at that.

Barro and Ursúa state the Euler equation of consumption between dates $t$ and $t+1$ for the equity return and the risk-free rate in their equations 6 and 7 , respectively. I take the difference of these equations and obtain the premium as follows:

$$
r^{e}-r^{f}=\gamma \sigma^{2}+p\left[\mathrm{E}(1-b)^{-\gamma}-\mathrm{E}(1-b)^{1-\gamma}-\mathrm{E} b\right] .
$$

If $b$ were constant, equation 6 would simplify to $r^{e}-r^{f}=\gamma \sigma^{2}+$ $p\left\{b\left[\mathrm{E}(1-b)^{-\gamma}-1\right]\right\}$. This is the same as equation 8 in the paper. However, the authors do not assume that $b$ is constant, and therefore their equation 8 is incorrect.

Even after this correction, another correction needs to be made in my own equation 6 . Based on my discussion above, I correct equation 6 by replacing $p$ with $p /(\pi+p)$, the unconditional probability of a disaster state at the end of the year, and state it as follows:

$$
r^{e}-r^{f}=\gamma \sigma^{2}+\frac{p}{(\pi+p)}\left[\mathrm{E}(1-b)^{-\gamma}-\mathrm{E}(1-b)^{1-\gamma}-\mathrm{E} b\right] .
$$

As I argued above, $1-b$ should be thought of as the one-year consumption ratio in disaster years and not as the cumulative trough-to-peak consumption ratio in these years. Since I do not have the moments for $\mathrm{E}(1-b)^{-\gamma}$ and $\mathrm{E}(1-b)^{1-\gamma}$ either over one year or over the cumulative trough-to-peak period, I do a calibration in the special case where $b$ is constant. The point of this exercise is to demonstrate that the authors' approach and mine yield results that differ by an order of magnitude, when in both cases $b$ is treated as constant. In both cases I set $\gamma=3.5, p=0.0363$, and $\pi=0.278$ and suppress the term $\gamma \sigma^{2}$, as the authors do. 
First, I consider the authors' approach. When I set $1-b=0.781$, equation 7 yields an annual equity premium $r^{e}-r^{f}=0.0348$. By contrast, when I set $1-b=0.928$, which I argued is the correct way to think about the annual shock in a disaster state, equation 7 yields an annual equity premium $r^{e}-r^{f}=0.0025$. Although both numbers are small because I have suppressed uncertainty about $b$ for reasons of convenience, the point is that the premium 0.0025 is less than one-tenth of the premium 0.0348 . I recommend that the authors provide the annual moments for $\mathrm{E}(1-b)^{-\gamma}$ and $\mathrm{E}(1-b)^{1-\gamma}$ and repeat the above comparison without the assumption that $b$ is constant.

As I argued above, there is an alternative and intuitive way to make the same point. I finesse the controversial issue as to whether the entire shock to consumption occurs in the year of onset of the disaster or is distributed over all years of the disaster, by choosing the length of one period in the model to be 3.6 years instead of one year. In this case it does not matter which year during the disaster period is the year in which consumption drops. Then the baseline case in the authors' table 10 says that their model of economic disasters generates a premium of $0.059-$ 0.01 , or 4.9 percent, over 3.6 years. However, the historical equity premium over a holding period of 3.6 years is, as noted above, approximately $3.6 \times 6=21.6$ percent, which again is less than a quarter of the historical equity premium.

Barro and Ursúa do not provide empirical evidence to support giving special status to one year as the length of time over which the entire shock to consumption occurs upon the onset of a disaster. Had they instead picked one month as the critical period, the modified calibration above would predict a one-month premium of 4.9 percent, which is almost ten times the historical one-month premium of $6 / 12=0.5$ percent.

I have argued that Barro and Ursúa do not deliver a convincingly calibrated model of economy-wide disasters that explains a substantial fraction of the historically observed equity premium. The reason is that the annual drop in consumption during these disasters is too small to explain the premium, even after allowing for the fact that the incidence of negative shocks to consumption growth increases upon the onset of an economic disaster. The authors' device of attributing the entire peak-to-trough drop in consumption to the year of onset of the disaster is simply counterfactual and double-counts the increased incidence of negative shocks to consumption growth after the onset of the disaster. In a recent empirical study, Christian Julliard and Anisha Ghosh find that economy-wide disasters, 
along the lines of Barro's 2006 paper and the present one, do not explain the cross section of asset returns..$^{13}$

There is, however, an alternative interpretation of economic disasters, namely, as periods where the incidence of large negative idiosyncratic income shocks increases at the household level. ${ }^{14}$ These shocks may largely wash out at the aggregate level and may not even show up in aggregate consumption data. Nevertheless, these shocks potentially play a major role in the pricing of financial assets through the household Euler equations of consumption, provided they are persistent and uninsurable. Given that markets provide grossly incomplete consumption insurance, models that account for these shocks show promise for understanding the source of the equity premium and of the premia of subclasses of financial assets.

GENERAL DISCUSSION Robert Hall commented on the history of the equity premium literature, starting with Lars Peter Hansen and Kenneth Singleton's 1983 paper on the temporal behavior of asset returns. He suggested that one could measure the progress of this literature by the plausibility of the coefficient of relative risk aversion required to match the equity premium. Papers such as this one tend either to overestimate the relative risk aversion coefficient or to fail to explain the equity premium. He suggested that the authors' relative risk aversion coefficient of 3.5 was unreasonably high.

William Brainard noted that international portfolio diversification is substantial and has fluctuated greatly since the late nineteenth century. The authors' assumption that economies are closed greatly simplifies the analysis but may bias the results. For example, it presumably overstates the risk

13. Julliard and Ghosh, "Can Rare Events Explain the Equity Premium Puzzle?" working paper, London School of Economics, 2008.

14. Such models were suggested by Mehra and Prescott in an early draft of their 1985 paper, "The Equity Premium: A Puzzle," working paper, Carnegie-Mellon University, 1980; and by N. Gregory Mankiw, "The Equity Premium and the Concentration of Aggregate Shocks," Journal of Financial Economics 17, no. 1 (1986): 211-19. George M. Constantinides and Darrell Duffie, “Asset Pricing with Heterogeneous Consumers," Journal of Political Economy 104, no. 2 (1996): 219-40, introduced such a model in an intertemporal economy. Alon Brav, George M. Constantinides, and Christopher C. Geczy, "Asset Pricing with Heterogeneous Consumers and Limited Participation: Empirical Evidence," Journal of Political Economy 110, no. 4 (2002): 793-824, provided empirical support for the model. See also Tom Krebs, "Testable Implications of Consumption-Based Asset Pricing Models with Incomplete Markets," Journal of Mathematical Economics 40, no. 1-2 (2004): 191-206. 
faced by a typical investor and therefore understates the degree of risk aversion required to rationalize observed risk premia.

Christopher Sims observed that high rates of risk aversion may not be needed to explain asset pricing paradoxes. Instead, it is possible that disasters follow different probability distributions. Because these events are so rare, however, it is difficult to measure this with confidence. The authors' figure 1 caps the disaster size at 70 percent, but it is unclear whether the distribution tapers off slowly toward this maximum or falls off sharply. These two behaviors have wildly different implications for asset pricing. Therefore, experimenting with different probability distributions would be useful.

William Nordhaus cited research on the probability distributions of other war statistics, such as the number of fatalities, and suggested that consumption shocks might be similarly distributed. He said that these variables seem to follow Cauchy distributions, which is problematic because standard estimation techniques then do not work: variances and means are infinite. Nordhaus also noted that the authors assumed that disasters led to permanent level shifts in consumption, and this applied even to cases of large wars. The authors' figures suggested trend reversion following each of the major wars, so the consumption shock would be overestimated under the assumption of a permanent shock.

Lawrence Summers pointed out that consumption and asset returns in many of the countries in this dataset are highly correlated during major crisis periods such as World War II. He questioned the value of including highly correlated observations, which may not add any more information than, say, dividing North and South Carolina into separate observations in a U.S. dataset.

Summers also wondered whether the Euler equation makes sense during wars: consumption is rationed, so the marginal utility of income cannot be inferred from observed consumption. Similarly, in periods of financial crisis, international capital flows and exchange rate movements can make it difficult to accurately assess the behavior of asset markets. For example, during the Mexican financial crisis of 1995, the peso collapsed but the Mexican stock market appeared to rally. The reason was that the stock market was priced in dollars, and because the peso was falling faster than stock prices, the dollar value of stocks increased. Stock prices may therefore have provided an inaccurate description of what was happening in Mexican asset markets during this period. David Romer wondered whether asset returns were measured accurately during periods of hyperinflation, and whether the authors had been successful in dealing with periods of default. A few observations where the rate of return on government bonds was close to minus 100 percent might affect the picture dramatically. 